\title{
Potential Flood Hazards and Hydraulic Characteristics of Distributary-Flow Areas in Maricopa County, Arizona
}

By H.W. HJALMARSON

U.S. GEOLOGICAL SURVEY

Water-Resources Investigations Report 93-4169

Prepared in cooperation with the FLOOD CONTROL DISTRICT OF MARICOPA COUNTY

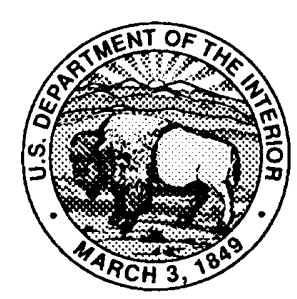




\title{
U.S. DEPARTMENT OF THE INTERIOR BRUCE BABBITT, Secretary
}

\author{
U.S. GEOLOGICAL SURVEY
}

Gordon P. Eaton, Director

For additional information write to:

District Chief

U.S. Geological Survey Water Resources Division 375 South Euclid Avenue Tucson, AZ 85719-6644
Copies of this report can be purchased from:

U.S. Geological Survey

Earth Science Information Center

Open-File Reports Section

Box 25286, MS 517

Denver Federal Center

Denver, CO 80225 


\section{CONTENTS}

Page

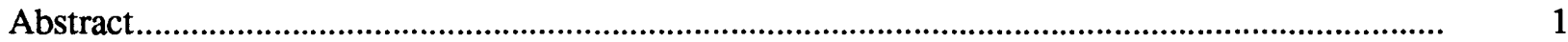

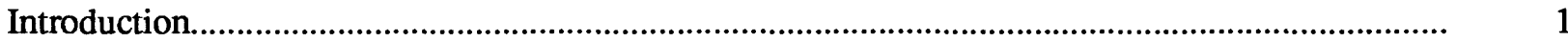

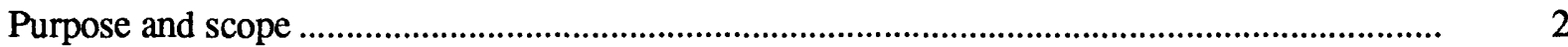

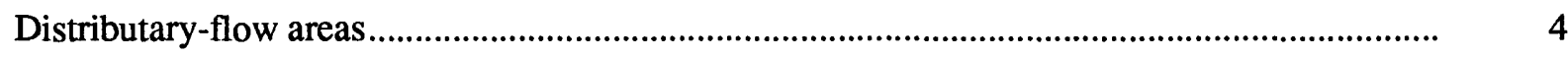

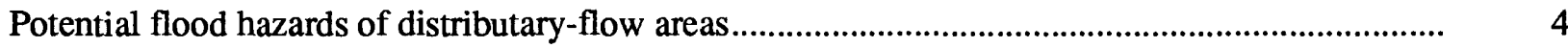

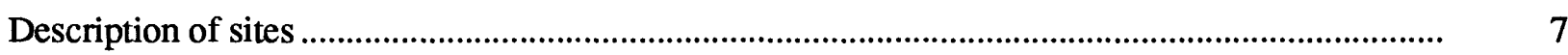

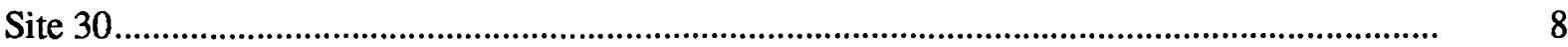

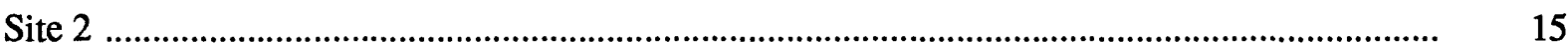

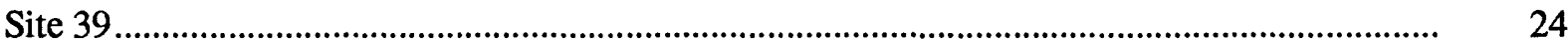

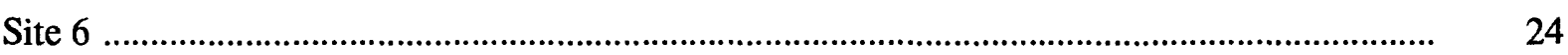

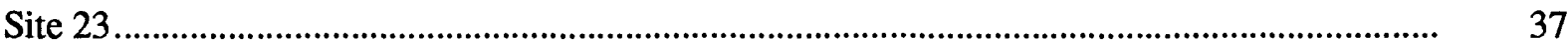

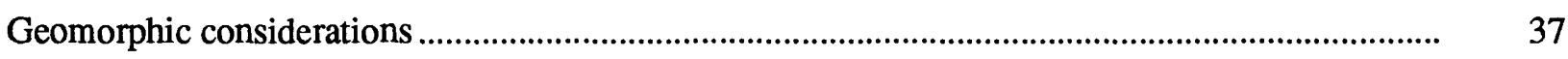

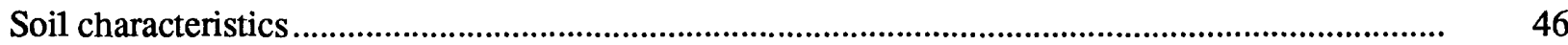

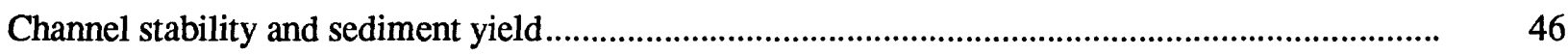

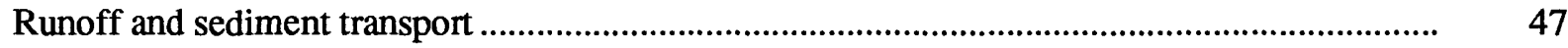

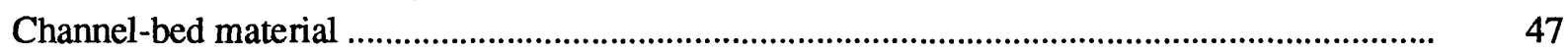

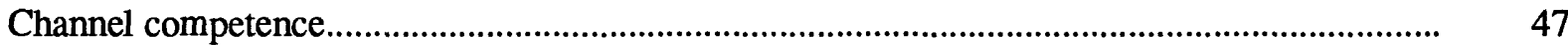

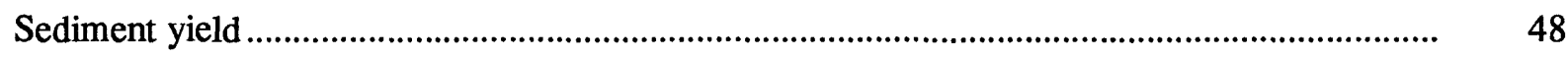

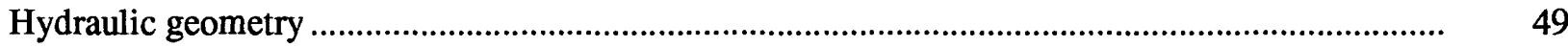

Summary and conclusions .......................................................................................... 54

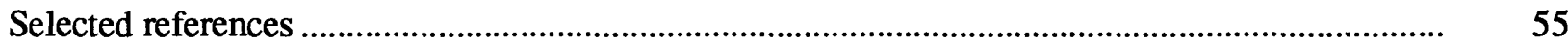

\section{FIGURES}

1. Map showing study area and distributary-flow sites, distributary-flow areas, bedrock mountainous areas, and alluvial-plain areas

2. Map showing topography, distributary channels, primary diffluence, larger ridge areas that are above the potential level of the 100-year flood, location and view angle of photographs, and location of cross sections for site 30

3. Photographs showing site 30 , primary diffluence, and distributary-flow area

4. Graphs showing stream profile and average slope of the west channel between topographic-map contours showing location of primary diffluence and toe of distributary-flow area for site 30 ....

5. Cross sections of primary diffluence and upper distributary-flow area showing approximate level of selected T-year floods for site 30

6. Map showing topography, distributary channels, primary diffluence, larger ridge areas that are above the potential level of the 100-year flood, location and view angle of photographs, and location of cross sections for site 2 
7. Graphs showing stream profile and average slope of channel between topographicmap contours showing location of primary diffluence and toe of distributary-

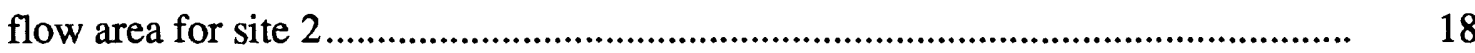

8. Photographs showing site 2, primary diffluence, and distributary-flow area .............. $\quad 19$

9. Cross sections of primary diffluence and upper distributary-flow area showing approximate level of the 100 -year flood for site 2

10. Map showing topography, distributary channels, primary diffluence, larger ridge areas that are above the potential level of the 100-year flood, location and view angle of photographs, and location of cross sections for site 39

11. Graphs showing stream profile and average slope of channel between topographicmap contours showing location of primary diffluence and toe of distributaryflow area for site 39 .

12. Photographs showing site 39 , primary diffluence, and distributary-flow area

13. Cross sections of primary diffluence and upper distributary-flow area showing approximate level of the 100-year flood for site 39

14. Photograph looking downstream and southwest at the primary diffluence and distributary-flow area at site 36 .

15. Map showing topography, distributary channels, primary diffluence, larger ridge areas that are above the potential level of the 100-year flood, location and view angle of photographs, and location of cross section for site 6

16. Photographs showing site 6, primary diffluence, and distributary-flow area

17. Cross section of primary diffluence and upper distributary-flow area showing approximate level of the 100-year flood for site 6

18. Graphs showing stream profile and average slope of channel between topographicmap contours showing location of primary diffluence for site and toe of distributary-flow area for site 6

19. Map showing topography, distributary channels, primary diffluence, larger ridge areas that are above the potential level of the 100-year flood, location and view angle of photographs, and location of cross sections for site 23

20. Photographs showing site 23, primary diffluence, and distributary-flow area .............

21. Cross sections of primary diffluence and along the main channel in the upper distributary-flow area showing approximate level of the 2-, 10-, and 100-year floods for site 23

22. Graphs showing stream profile and average slope of channel between topographicmap contours showing location of primary diffluence and toe of distributaryflow area for site 23 .

23. Cross section of upper distributary-flow area about 2,800 feet downstream from the primary diffluence at the 1,560-foot elevation contour of site 23 .

24. Schematic cross sections at equal distances from the primary diffluence 
1. Characteristics of flood-hazard degrees ............................................................................

2. Characteristics of channel cross sections for 100 -year flood at site 2 ........................... 22

3. Peak discharge and competence at the 2-, 10-, and 100-year recurrence intervals and grain sizes of the channel bed (D50, D75, D84, and D90) at the primary diffluences for sites in and near Maricopa County, Arizona

4. Theoretical and average hydraulic-geometry exponents for channel cross sections ... 51

5. Coefficients and exponents for width, depth, and velocity for the 2-, 10-, and 100 -year floods at the primary diffluence of sites in Maricopa County, Arizona... 52

6. Characteristics of channel cross sections for 2- and 10-year floods at site 23............ 53

7. Coefficients and exponents for width, depth, and velocity for the 2-, 10-, and 100 -year floods at channel cross sections of site 23.

CONVERSION FACTORS

\begin{tabular}{lll}
\hline Multiply & By & To obtaln \\
\hline inch (in.) & 25.4 & millimeter \\
foot $(\mathrm{ft})$ & 0.3048 & meter \\
mile (mi) & 1.609 & kilometer \\
square mile $\left(\mathrm{mi}^{2}\right)$ & 2.590 & square kilometer \\
cubic foot per second $\left(\mathrm{ft}^{3} / \mathrm{s}\right)$ & 0.02832 & cubic meter per second \\
\hline
\end{tabular}

Air temperatures are given in degrees Fahrenheit $\left({ }^{\circ} \mathrm{F}\right)$, which can be converted to degrees Celsius $\left({ }^{\circ} \mathrm{C}\right)$ by the following equation:

$$
{ }^{\circ} \mathrm{C}=5 / 9\left({ }^{\circ} \mathrm{F}\right)-32
$$

\section{VERTICAL DATUM}

Sea level: In this report, "sea level" refers to the National Geodetic Vertical Datum of 1929-A geodetic datum derived from a general adjustment of the first-order level nets of the United States and Canada, formerly called Sea Level Datum of 1929. 


\title{
Potential Flood Hazards and Hydraulic Characteristics of Distributary-Flow Areas in Maricopa County, Arizona
}

\author{
By H.W. Hjalmarson
}

\begin{abstract}
Flood hazards of distributary-flow areas in Maricopa County, Arizona, are related to the stability of flow paths, which can be defined using topographic maps, aerial photographs of distributary-flow areas, soil characteristics, and channel cross sections. Five distributary-flow areas that represent the range of flood-hazard degree associated with flow-path stability are discussed in this report. At sites where flow paths are unstable, channels are commonly perched above adjacent low-lying land, which is inundated by floodwaters that overtop the banks. Sites with stable paths of flow have abundant mature palo verde trees and other vegetation along distributary channels that are incised into the landform. Floodflow is apportioned through a network of distributary channels at one site using channel conveyance-slope methods.

The 2-year flood can transport the noncohesive bed material in the main channel at the primary diffluence of the sites selected for the study. The channel competence represented by the maximum grain size that could be moved at the peak discharge of the 2-year flood is typically at least twice that needed to move 90 percent of the bed material.

The average value of width, depth, and velocity exponents of the hydraulic-geometry relations at the primary diffluences of the sites are similar to theoretical exponents for streams with cohesive bank material and the average exponents of stream channels in other areas in the United States. Values of the exponent of channel width, however, show a high degree of unexplained scatter, thus the use of average hydraulic-geometry relations is considered inappropriate for characterizing flood hazards for specific distributary-flow areas in Maricopa County.

No evidence has been found that supports the use of stochastic modeling of flows or flood hazards of many distributary-flow areas. The surface of many distributary-flow areas is stable with many distributary channels eroded in the calcreted surface material. Many distributary-flow areas do not appear to be actively aggrading today, and the paths of flow are not changing.
\end{abstract}

\section{INTRODUCTION}

Distributary flow is floodflow that divides into two or more distributary channels. The separation of flow occurs at the diffluence, the point at which the channel divides. Some distributary channels have a terrace that appears to be independent of other distributary channels. Many distributaryflow areas contain several diffluences where channels divide. The primary diffluence (PD) is the most upstream diffluence where the 100-year flood is last contained in a single channel and flood plain. For active alluvial fans, which are considered a type of distributary-flow area (DFA), the apex is the same as the PD.

For this study, active alluvial fans are considered geomorphologic features that are presently aggrading where sediment transported from the drainage basin above the PD during periods of runoff is deposited on and adjacent to the fan. Other alluvial fans in Arizona are not actively aggrading and are undergoing change that is related to the progressive weathering of the drainage basins above the PD. As the size of the DFA progressively increases, the amount of sediment delivered to a 
unit area within the DFA past the PD progressively decreases. The result of this process is the erosion of many distributary channels in the fan surfaces. Many of the fan surfaces appear to have stable-incised flow paths with small aggrading areas below some diffluences where incised channels divide into two or more distributary channels. Many of the DFA's for this study may be considered by some geomorphologists to be alluvial fans in various states of progressive change (Harvey, 1989, p. 142-143). Because it is not the purpose of this study to delve deeply into landform processes especially where there may be disagreement among geomorphologists, fans that may have undergone long-term erosion of the drainage basins simply are identified as DFA's.

In addition to the division of channels on DFA's, the channels typically recombine. On some DFA's, many forks and joins exist, and the floodflow paths appear chaotic or random in time and space. In many other DFA's, the network of distributary channels appear chaotic, but the location of the channels appears stable. The number of channel forks commonly exceed the number of channel joins.

Increasing urbanization has occurred on alluvial fans in Maricopa County and other areas in the arid southwestern United States. Although geologists have described alluvial fans in terms of geomorphic processes, little information is available on potential flood hazards of DFA's that can be used by land-use planners, highway engineers, and home builders. Several investigators have described the unique character of floods on DFA's (Hjalmarson and Kemna, 1991; DMA Consulting Engineers, 1985; Dawdy, 1979, 1981; and French, 1987, 1992) but few have produced published maps and photographs that depict potential flood hazards of DFA's. For this reason, the U.S. Geological Survey, in cooperation with the Flood Control District of Maricopa County, began a study of flood hazards of DFA's in and near Maricopa County.

The potential flood hazards of DFA's can be severe and commonly are more difficult to define reliably than the potential flood hazards of tributary-stream systems. The drainage-basin area from which floodflow at a particular distributary channel emanates commonly cannot be accurately defined. The distribution of floodflow in the network of distributary channels can change from one flood to the next. The geometry of the channels changes during floodflow, and on some DFA's, new channels can form, and channels may move laterally. On active DFA's, the floodflow paths can change, and the distribution of floodflow in the network of distributary channels may change.

Many of the DFA's in Arizona appear to be on stable land surfaces where there is little aggradation and degradation in engineering time (100 to a few hundred years) and long periods of no streamflow are typically interspersed with short-lived episodes of runoff (Hjalmarson, 1991). In some places, there are large amounts of scour and fill during floods but the land surfaces generally appear stable. At diffluences, the floodflow leaves the confines of defined channels, spreads laterally, and loses energy. Some of the sediment transported during runoff is deposited locally, and a lobe of deposited sediment is formed downstream from the diffluence. Much of the locally deposited sediment appears to be transported by small floods and runoff to the toe of the DFA's. In southwestern Arizona, no measurements were made of the amount and rate of aggradation below diffluences; however, the process appears to be slow.

\section{Purpose and Scope}

The purposes of this report are (1) to describe the variety of potential flood hazards of distributary-flow areas in Maricopa County, (2) to discuss the stability of the flow paths and stream channels and the sediment transported to the DFA's, and (3) to present hydraulic-geometry relations for the PD's of the DFA's in Maricopa County. Hjalmarson and Kemna (1991) studied DFA's at 39 sites in southwestern Arizona, including 15 sites in Maricopa County, and described the differences in the flood characteristics of DFA's in Arizona (fig. 1). This report presents additional data on sites studied by Hjalmarson and Kemna and an additional description of relative flood characteristics of the DFA's of the sites in Maricopa County for use by flood-plain managers, hydrologists, and engineers. 


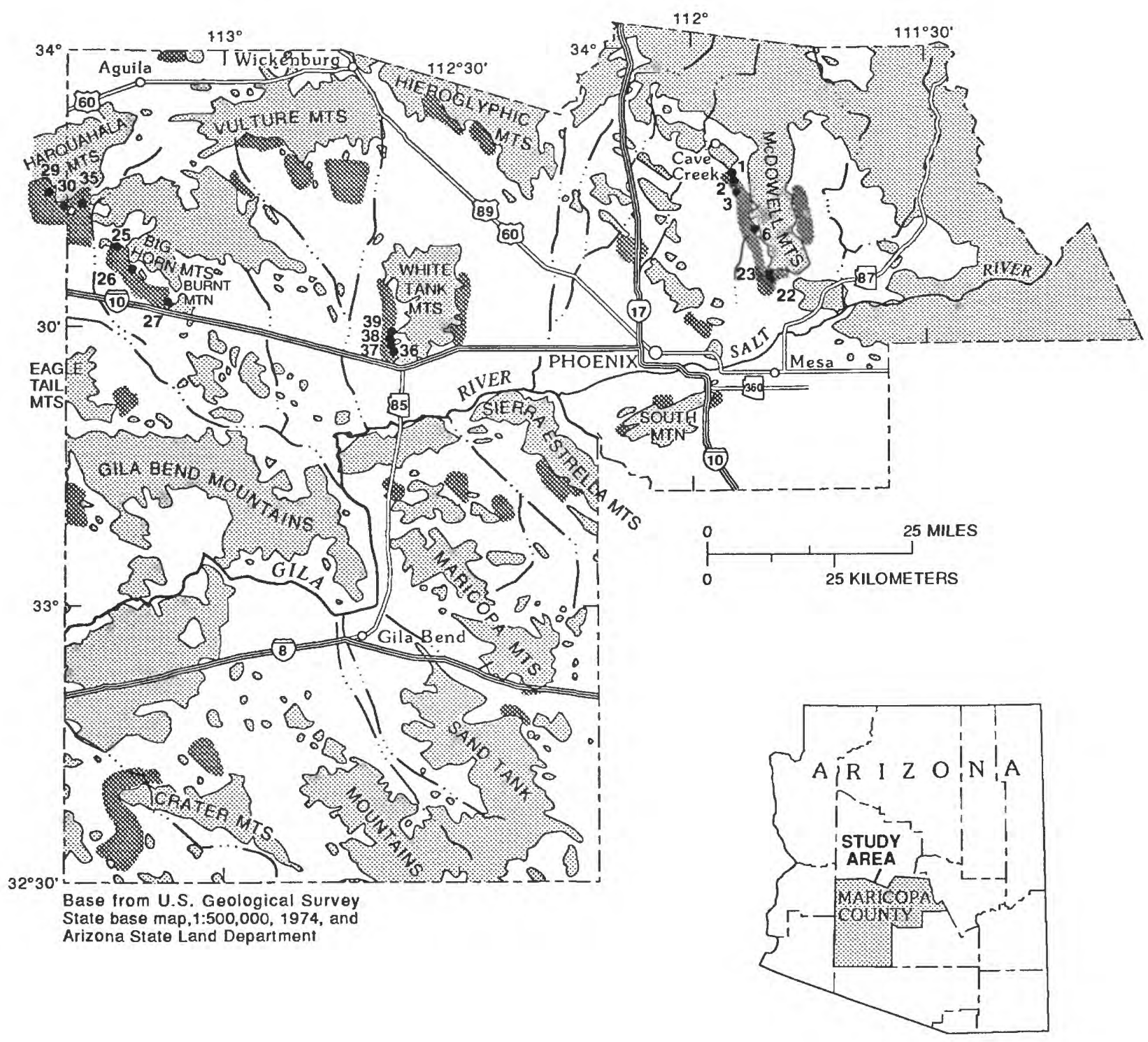

EXPLANATION
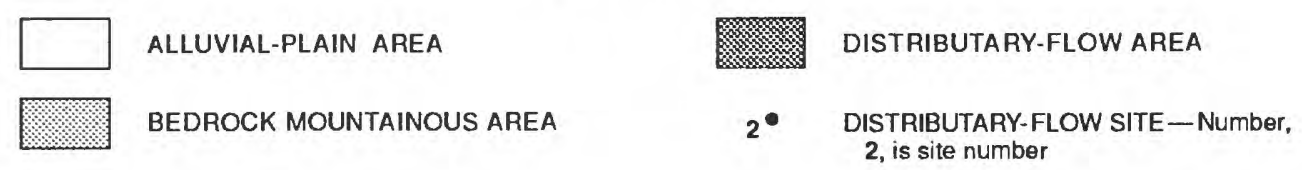

Figure 1. Study area and distributary-flow sites, distributary-flow areas, bedrock mountainous areas, and alluvial-plain areas. 
Five sites were selected to represent the nature of flood hazards of DFA's in Maricopa County and southwestern Arizona. The flood characteristics of these sites are described and contrasted in this report. Fundamental geomorphologic considerations useful for the interpretation of field observations of aggrading and degrading channels, incised channels, and systems of distributary channels on pediments and Pleistocene sediments are discussed briefly. Soil characteristics useful for assessing the stability of the distributary channels and surfaces of distributary-flow areas also are described.

Channel stability, sediment yield, and hydraulic-geometry characteristics are described using 16 of the original 39 sites selected by Hjalmarson and Kemna (1991). The 16 sites are in or near Maricopa County (fig. 1) and are considered representative of most DFA's in Maricopa County. A possible exception may be the DFA's on the eastern slopes near the northern end of the McDowell Mountains where the slopes are steep, and there is little topographic relief across the DFA surface perpendicular to flow.

\section{Distributary-Flow Areas}

The most common systems of stream channels are tributary, but in southern and central Arizona, many systems are distributary. Tributary streams form a network of channels that feed larger streams downstream. During periods of flooding, the tributaries collect overland flow and feed floodwater to receiving streams causing the amount of floodflow to progressively increase downstream. Tributary channels generally are on degrading landforms.

Some stream systems, such as in the arid southwestern United States, have developed a network of distributary channels. Distributary channels form a radiating pattern like an open fan that spreads from a single channel upstream. Distributary channels normally are on aggrading landforms or land that was formed by depositional processes and is now stable or eroding.

Distributary-flow areas (DFA's) have at least one channel fork or diffluence where at least two channel links are formed. DFA's are not constructed landforms as such, rather areas characterized by a distributary-drainage pattern as opposed to the more common nonradiating tributary-drainage pattern. Because floodflow on alluvial fans commonly is distributary, alluvial fans-a depositional landform-are considered to be DFA's. Floodflow on some pediments-an eroded landform-is distributary in places, and such areas also are considered to be DFA's.

A distributary channel flows away from and is separate from the main channel, and commonly does not return to the main channel. Distributary flow is diffuse but contains flow where there is at least one distinct diffluence at the outflowing branch of a stream. A system of distributary channels has channel forks, joins, and outlets. Sheetflow also is diffuse but is uncontained, spreads freely, and is not considered to be distributary flow. Floodflow that moves from distributary-flow areas onto base-level plains, such as playas, commonly is called sheetflow.

Most DFA's in southwestern Arizona are on piedmont plains (Hjalmarson and Kemna, 1991). Some DFA's are on eroded old-fan relics (Pleistocene sediments), a few are on a veneer of soil overlying a pediment, and others are on alluvial slopes in the lower part of the piedmont plain. A few DFA's are within mountains and upstream from mountain passes. Most DFA's are on the south- and west-facing slopes of mountains that separate the many desert valleys. DFA's in southwestern Arizona come in a wide variety of locations, ages, shapes, and sizes.

\section{POTENTIAL FLOOD HAZARDS OF DISTRIBUTARY-FLOW AREAS}

Distributary-flow areas (DFA's) are attractive for development because vegetation is denser than in nearby tributary-flow areas and foundation structures are relatively easy to construct. However, significant flood hazards exist in the DFA's. The stream channels are small in relation to the potential width of the 100 -year flood, and the banks of the channels commonly are lined with large desert trees and bushes. Because the slope of the sand-bed channels is steep, floodflow velocity is high and approaches near-critical or perhaps supercritical velocity in the main channels. The potential flood hazard is easily overlooked along the channels that emanate from the PD's 
(Hjalmarson, 1978). For example, several residential structures in the distributary channels of sites 1 and 2 near the community of Cave Creek (fig. 1) may experience structural damage and damage to contents during large floods. Bank erosion near the structures is expected when blocked flow paths relocate.

The differences in geomorphic and hydrologic characteristics among DFA's in Arizona, Nevada, and southern California result in differences in flood hazards among these areas. The ratio of drainage area to the area of the DFA generally is smaller for DFA's in southern Arizona than in Nevada and southern California (Hjalmarson and Kemna, 1991). Less floodflow occurs at the PD for the same size DFA's in southern Arizona than in Nevada or southern California. Apparently, because of the smaller discharge intensities for DFA's in Arizona (flood-peak discharge at the PD divided by the DFA), the paths of floodflow are more stable and less prone to lateral migration and sudden relocation. Floodflow paths of some DFA's on pediments in Arizona also are stabilized by the underlying bedrock at shallow depths as described by Leopold and others (1964, p. 494).

In addition to the influence of the underlying pediment and possibly the old-fan remnants underlying some inset DFA's, many surfaces of DFA's are covered with desert varmish and (or) are crusted by calcrete deposits (Harvey, 1989, p. 144). The desert varnish indicates long-term erosional and depositional stability. These surfaces resist erosion and lateral movement of distributarystream channels. Where the sediment supply to the DFA's of these surfaces is small, channels may be incised into the surfaces (Harvey, 1989, p. 153) resulting in dissected alluvial fans. Hjalmarson and Kemna (1991) observed many of these dissected fans that had different potential flood hazards than fans that continued to aggrade during the Holocene Epoch. According to Harvey (1989, p. 153), the sediment yield to some DFA's has been less during the Holocene than it was during the Pleistocene Epoch when the fans aggraded. The surfaces are undergoing dissection. Although Hjalmarson and Kemna were studying the potential flood hazards of DFA's and not the processes that formed these depositional landforms, it was apparent that many of the distributary channels had eroded into the cemented Pleistocene sediments, and channel movement was restricted by the tree-lined erosion-resistant banks.

A study was made of a recent large flood on the DFA below Wild Burro Canyon on the western slopes of the Tortolita Mountains north of Tucson, Arizona (Phil Pearthree, geologist, Arizona Geological Survey, written commun., 1992). The flood occurred on July 27, 1988, and is the largest known flood in Wild Burro Canyon on the basis of a reconstruction of past floods using paleoflood techniques. With few exceptions, the floodflow on the DFA followed the preflood network of channels. Documentation of the amount and extent of other large floods on DFA's in Arizona is not available. The cemented conglomerate under much of the DFA studied by Pearthree appeared to be only thinly covered with alluvium, and the configuration of the surface of the cemented conglomerate may have restricted channel avulsions and lateral movement. Also, the cohesive soils and vegetation along the channels restricted channel movement. The floodflow of this large flood occupied the existing network of many distributary channels with no relocation of flow paths.

The potential flood hazards on DFA's were defined by Hjalmarson and Kemna (1991, p. 21) using a numerical value of 1 to 10 . A degree of flood hazard of 10 was used for DFA's with flow paths that appear to change location over the entire DFA and where the entire DFA potentially can be inundated during the 100-year flood. A flood-hazard degree of 1 was assigned to a single diffluence with two stable distributary channels. Classic hydraulic methods can be used to define the distribution and extent of floodflow for a flood-hazard degree of 1 but not for a flood-hazard degree of 10 (table 1 ).

A probability-based method for defining potential flood hazards of alluvial fans (DFA's with a degree of flood hazard of 10 and probably 9) was developed by Dawdy (1979). The method is based on the assumption that the likelihood of flooding is equal for any point along an elevation contour on an alluvial fan. Several investigators have questioned this assumption (French, 1992; Burkham, 1988, p. 15-16; Hjalmarson and Kemna, 1991, p. 3). Dawdy's method also is based on an assumption of a quasi-equilibrium channel condition that is rarely observed on alluvial fans in Arizona. Single and 
Table 1. Characteristics of flood-hazard degrees

[>, greater than]

\begin{tabular}{|c|c|c|c|}
\hline $\begin{array}{l}\text { Flood-hazard } \\
\text { degree }\end{array}$ & $\begin{array}{l}\text { Number of } \\
\text { distributary } \\
\text { channels }\end{array}$ & Channel stability & $\begin{array}{l}\text { Extent of flooding and potential movement } \\
\text { of flow paths }\end{array}$ \\
\hline 1 & 2 & Stable channels & $\begin{array}{l}\text { Flooding in defined channels. The amount and extent of } \\
\text { flooding can be defined, and flow in the channels is } \\
\text { separated by a high ridge. }\end{array}$ \\
\hline 2 & 2 & $\begin{array}{l}\text { Unstable channel geometry } \\
\text { at the primary diffluence }\end{array}$ & $\begin{array}{l}\text { Flooding confined to two defined channels, but the } \\
\text { distribution of floodflow can only be estimated. }\end{array}$ \\
\hline 3 & 2 & Stable channels & $\begin{array}{l}\text { Frequent flooding confined to defined channels separated } \\
\text { by a low stable ridge. Floodflow of the } 100 \text {-year flood } \\
\text { can spread over the ridge at a few places and coalesce. }\end{array}$ \\
\hline 4 & 2 & $\begin{array}{l}\text { Stable and unstable chan- } \\
\text { nels }\end{array}$ & $\begin{array}{l}\text { Frequent flooding confined to two defined channels } \\
\text { separated by a low ridge. Most of the ridge can be } \\
\text { overtopped by the } 100 \text {-year flood. }\end{array}$ \\
\hline 5 & $>2$ & $\begin{array}{l}\text { Stable and unstable } \\
\text { channels. Unstable } \\
\text { channel geometry at the } \\
\text { primary diffluence }\end{array}$ & $\begin{array}{l}\text { About two-thirds of the stable ridges are above the level } \\
\text { of the } 100 \text {-year flood. Flow paths are stable. }\end{array}$ \\
\hline 6 & $>2$ & Same as 5 above & $\begin{array}{l}\text { About one-half of the stable ridges are above the level of } \\
\text { the } 100 \text {-year flood. Flow paths are stable. }\end{array}$ \\
\hline 7 & $>2$ & Same as 5 above & $\begin{array}{l}\text { Less than one-half of the stable ridges are above the level } \\
\text { of the } 100 \text {-year flood. The channels are separated by } \\
\text { stable ridges. }\end{array}$ \\
\hline 8 & $>2$ & Unstable channels & $\begin{array}{l}\text { Floodwater of the } 100 \text {-year flood can overtop most of the } \\
\text { ridges. The location of the channels appears stable. }\end{array}$ \\
\hline 9 & $>2$ & Unstable channels & $\begin{array}{l}\text { Most of the ridges will be overtopped by the } 100 \text {-year } \\
\text { flood, and the location of the channels can change. }\end{array}$ \\
\hline 10 & $>2$ & $\begin{array}{l}\text { Unstable channels or only } \\
\text { small, poorly defined } \\
\text { channels }\end{array}$ & $\begin{array}{l}\text { Floodflow of the } 100 \text {-year and many smaller floods is } \\
\text { unconfined. Paths of flow appear random and are subject } \\
\text { to changes in time and space. }\end{array}$ \\
\hline
\end{tabular}

multiple channels are assumed to be formed by each flood and the channel stabilizes at $d D / d W=-0.005$ (Dawdy, 1979, p. 1408). Although the relation for this stable channel condition is not presented, the implication is that it represents an average condition at minimum energy (Froude number equals 1). However, there may be considerable scatter of observed channel conditions about this average condition. Dawdy's method lacks (1) a physical basis involving relations of motion and forces other than the assumption that flow is critical and (2) relations between observed independent and dependent variables. This method, however, appears to adequately estimate the potential flood hazard of DFA's with flood-hazard degrees of 9 and 10.
The flood-hazard degree of DFA's in southwestern Arizona where channels commonly are entrenched is related to physiographic and climatic characteristics of DFA's. Precise relations between flood-hazard degree and the physiographic and climatic characteristics are undefined and some relations are qualitative. Thus, several characteristics are needed to reliably estimate the flood-hazard degree. The definition of the flood-hazard degree is related to the randomness of stream channel links, the color of soils of the DFA, the density and distribution of vegetation, the presence and color of desert varnish, the spacing and depth of cut of the channels, and several drainage-area and DFA characteristics that are 
measurable on 7.5-minute topographic maps (Hjalmarson and Kemna, 1991, p. 36). The method used by Hjalmarson and Kemna (1991) for estimating the flood-hazard degree is considered reliable by the author where all the quantitative and qualitative methods are applied to a DFA and indicate a particular flood-hazard degree.

The primary diffluence and boundaries of DFA's are identified using methods based on physiographic and hydrologic characteristics (Hjalmarson and Kemna, 1991). Primary diffluences commonly exist where (1) ephemeral stream channels bifurcate, (2) channel slope decreases from that of the main channel upstream, (3) 100-year floodwater is confined and is at a lower elevation than oxidized soil and varnished rocks on adjacent banks, and (4) drainage texture changes downslope from the upper drainage basin. Distinguishing features that define DFA boundaries include topographic ridge lines, and changes in vegetation density, soil color, and drainage texture. Most DFA's with flood-hazard degrees of 5-10 have an unchanging drainage texture (uniform spacing of first- and second-order stream channels) in the upslope direction. Where DFA's overlap, the boundaries are estimated using defined ridge lines and the joins and divides of channels shared by the overlapping DFA's.

\section{DESCRIPTION OF SITES}

The detailed description of representative sites includes a map showing the DFA's with the location of channel cross sections and photographs, graphs showing the stream-profile characteristics, photographs of the channels and stream network, and cross sections of the channels. The aerial photographs show the stream network, location of the primary diffluence, the amount and distribution of the vegetation, the color differences of the soils and desert varnish, and the typically chaotic appearance of the distributary channels. The location and view angle of many of the photographs are shown on the map of the area and on oblique low-altitude aerial photographs. The symbol $(<B)$ depicts the location and view angle where the letter $B$ is the figure identification. The symbol $\rightarrow$ is for the direction and probable location of 100-year floodflow. The sites are discussed in the order of increasing degree of flood hazard.

A match point $(\odot)$ also is shown on a few of the aerial photographs and associated topographic maps. The match point depicts a location on the land surface common to both the photograph and map to aid the viewer in estimating distances on the land surface shown in the oblique aerial photograph.

Most sites have at least one photograph of the channel at the primary diffluence showing the height of the channel banks and a few photographs showing the grain size of channel material. The frame of the square grid shown in photographs taken at several locations on the ground has a 1.5-foot outside dimension on a side with an internal square of $1 \mathrm{ft}$ on a side and grid spacing of 1 in.

If the flow paths of a DFA are stable, the following characteristics are shown in photographs, maps, and cross sections.

1. The channels are eroded into cemented sediments and are not perched above the adjacent land.

2. Abundant large palo verde and other trees are along the banks of the distributary channels, and the interfluves are covered with scattered large trees. These large trees along the channel banks tend to stabilize the flow paths. Also, such trees would be washed away and not reach maturity if the flow paths were changing.

3. Channel movement is not observed on the DFA.

4. Soils are well developed with dark reddish-brown oxidation on the surface and a few inches below the surface.

If the flow paths of a DFA in southwestern Arizona are unstable, the following characteristics are shown in photographs, maps, and cross sections.

1. Channels and banks are perched above the adjacent land surface below the PD.

2. Large trees tend to be scattered over the DFA and not along the channel banks.

3. Channel movement on the DFA is depicted in aerial photographs. Although not shown in this report, the comparison of aerial photographs taken before and after a major flood and spanning a few tens of years is an excellent means of identifying channel movement. 
4. Soils of much of the DFA are yellow and tan on and near the surface.

5. Most of the interfluves in the upper DFA are below the expected level of the 100-year flood.

6. There is little or no desert varnish on stones in the DFA.

Site 30 represents the simplest degree of flood hazard in which the channel divides into two channels that remain separated. The middle of the range of flood-hazard degree is represented by site 2 that has a degree of 6 . The flood hazard of site 2 is discussed in detail because it represents typical conditions of DFA's with stable paths of flow in southern and central Arizona. Site 39 has a degree of 8 , and stable ridges separate the distributary channels. Site 6 has a degree of 9 where flow paths can change in the upper DFA and most of the ridges will be overtopped by the 100-year flood. Site 23 has the highest degree of flood hazard (10), with a perched main channel and banks in the upper DFA that are the result of recent debris deposition. The DFA's are in two main categories: (1) unstable DFA's that have an aggrading surface and unpredictable paths of flow and (2) stable DFA's that are characterized by a laterally stable network of incised channels. Sites 6 and 23 with respective degrees of flood hazard of 9 and 10 are unstable DFA's, and sites 2 and 30 with respective degrees of flood hazard of 6 and 2 are stable DFA's. Site 39 that has a degree of flood hazard of 8 appears to be a stable DFA because the paths of flow appear to be eroded into old-fan remnants of the Pleistocene Epoch; however, it has a relatively high degree of flood hazard because it appears that most of the interfluvial areas can be overtopped by the 100 -year flood.

Contrasting degrees of flood hazard at nearby sites are shown by sites 3 and 36 (fig. 1). Site 3 is adjacent and to the south of site 2 . Site 3 has a flood-hazard degree of 7 where two channels are separated by a large island of old-fan remnants in the upper DFA. Site 36 is near and to the south of site 39 on the western slopes of the White Tank Mountains and is an inset alluvial fan that has a flood-hazard degree of 10. An inset fan or DFA is formed during the Holocene Epoch on the surface of an old fan (old-fan remnants) of the Pleistocene Epoch. The paths of flow for site 39 appear to be much more unstable than the paths of flow of site 36 , which is a short distance to the north.

\section{Site 30}

Site 30 is near the western edge of Maricopa County on the southern slopes of the Harquahala Mountains. This site is an example of the simplest type of distributary flow (flood-hazard degree of 2) with a single diffluence and two distributary channels (fig. 2). A few hundred feet above the PD, tributary inflow occurs with a small amount of flow from a small channel to the west of the main channel (fig. 3A). The subtle hump in the stream profile (fig. 4) shown by the smaller slope (fig. 4B) reflects sedimentation at the confluence of the channels. The slope of the main channel steepens above the PD and then flattens. Just downstream from the PD, floodwater of large floods can overtop the left side of the main channel and enter a deeply incised distributary channel on the east through an overflow area (figs. 3A, 3B, and $3 \mathrm{D}$ ). At the PD, the 100-year flood is confined on the left by a high, erosion-resistant vertical bank (fig. 5A). The channel bed at the PD is composed of sand, gravel, and scattered boulders (fig. 3E). At the overflow area, the capacity of the channel is about equal to the peak discharge of the 10-year flood (fig. 5B). Floodflows less than about the 10-year flood remain in a single channel, whereas larger floods overtop the 4-foot-high left bank from the PD to about $600 \mathrm{ft}$ downstream and spill into a well-defined distributary channel to the east (figs. 5C and 3A-D).

The two distributary channels are separated by a high ridge downstream from the overflow reach (figs. 3C and 5C). About 1,300 ft downstream from the PD, the ridge is $500 \mathrm{ft}$ wide and $15-20 \mathrm{ft}$ above the two stream channels. The high separating ridge is covered with desert varnish (fig. 3B). The varnished interfluve is about $3 \mathrm{mi}$ long and about $2 \mathrm{mi}$ wide (maximum) with a tributary network of channels for local drainage (fig. 2). The soils of the interfluve area are well developed.

Both of the distributary channels contain reaches of branching channels. Where channel branches occur, the number of forks in the channels equals the number of joins. Also, the channel branches do not have terraces and appear to be part of a single, large channel that includes all the branches. 




Figure 2. Topography, distributary channels, primary diffluence, larger ridge areas that are above the potential level of the 100-year flood, location and view angle of photographs, and location of cross sections for site 30 . 
$A$, Looking downstream and south at the primary diffluence and upper distributary-flow area. The primary diffluence is two channels and a wide overflow area between the channels. The larger channel on the left conveys nearly all the flow and is considered the primary diffluence. The distributary flow to the left occurs only during high flows and is the result of flow that overtops the 4-foot-high left bank of the larger channel. The frame of the square grid is 1.5-foot outside dimension with an internal square of 1 foot on a side and grid spacing of 1 inch.
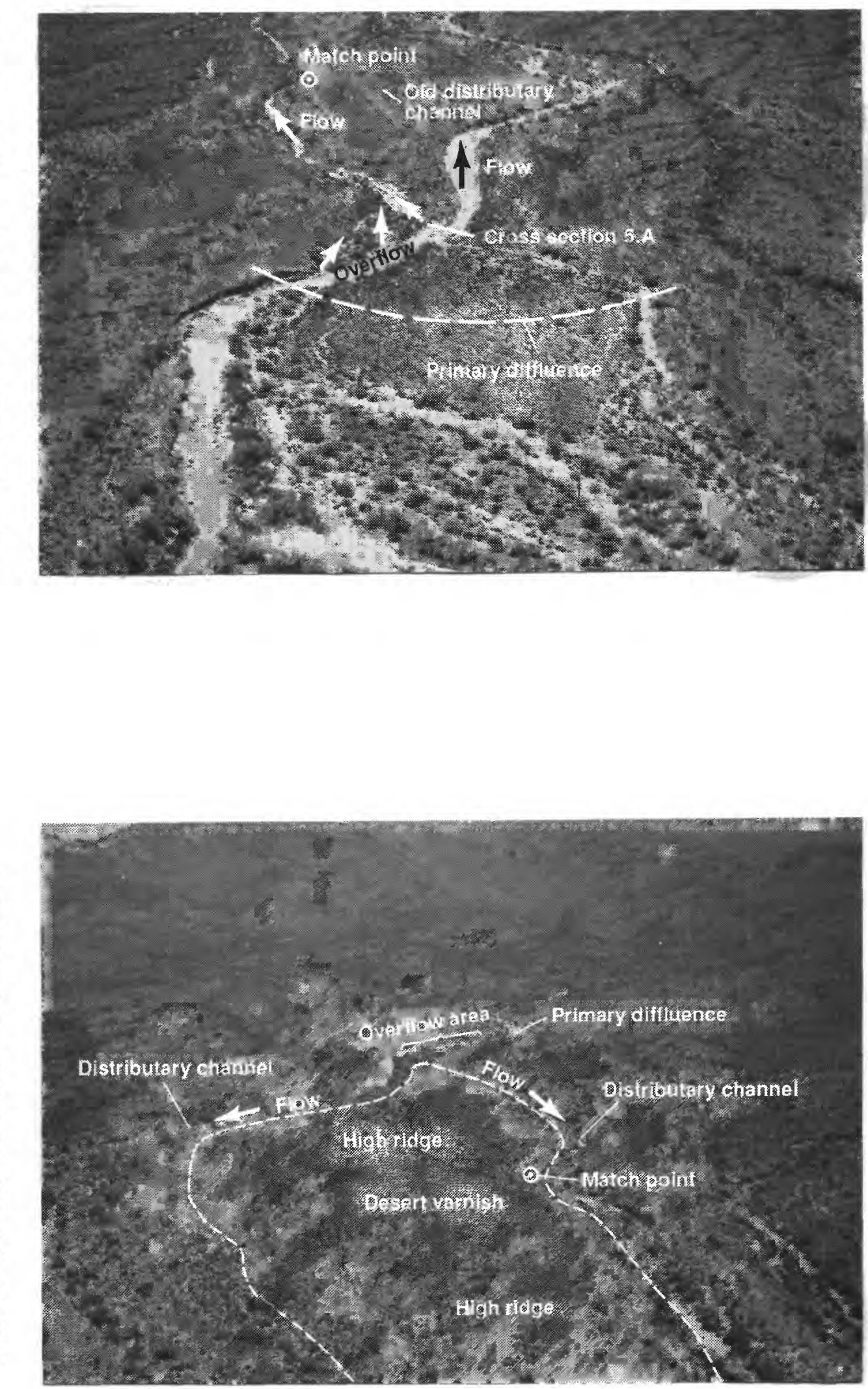

$B$, Looking upstream at the primary diffluence and two distributary channels. Considerable desert varnish is on the old-fan remnant between the channels in the foreground of the scene. The drainage basin is much of the mountainous area in the background. The ridge between the distributary channels is about 10 feet above the maximum level of the 100-year flood and about 1520 feet above the channel beds. Match point corresponds to match point on figures 2 , $3 \mathrm{~A}$, and $3 \mathrm{C}$.

Figure 3. Site 30, primary diffluence, and distributary-flow area. 

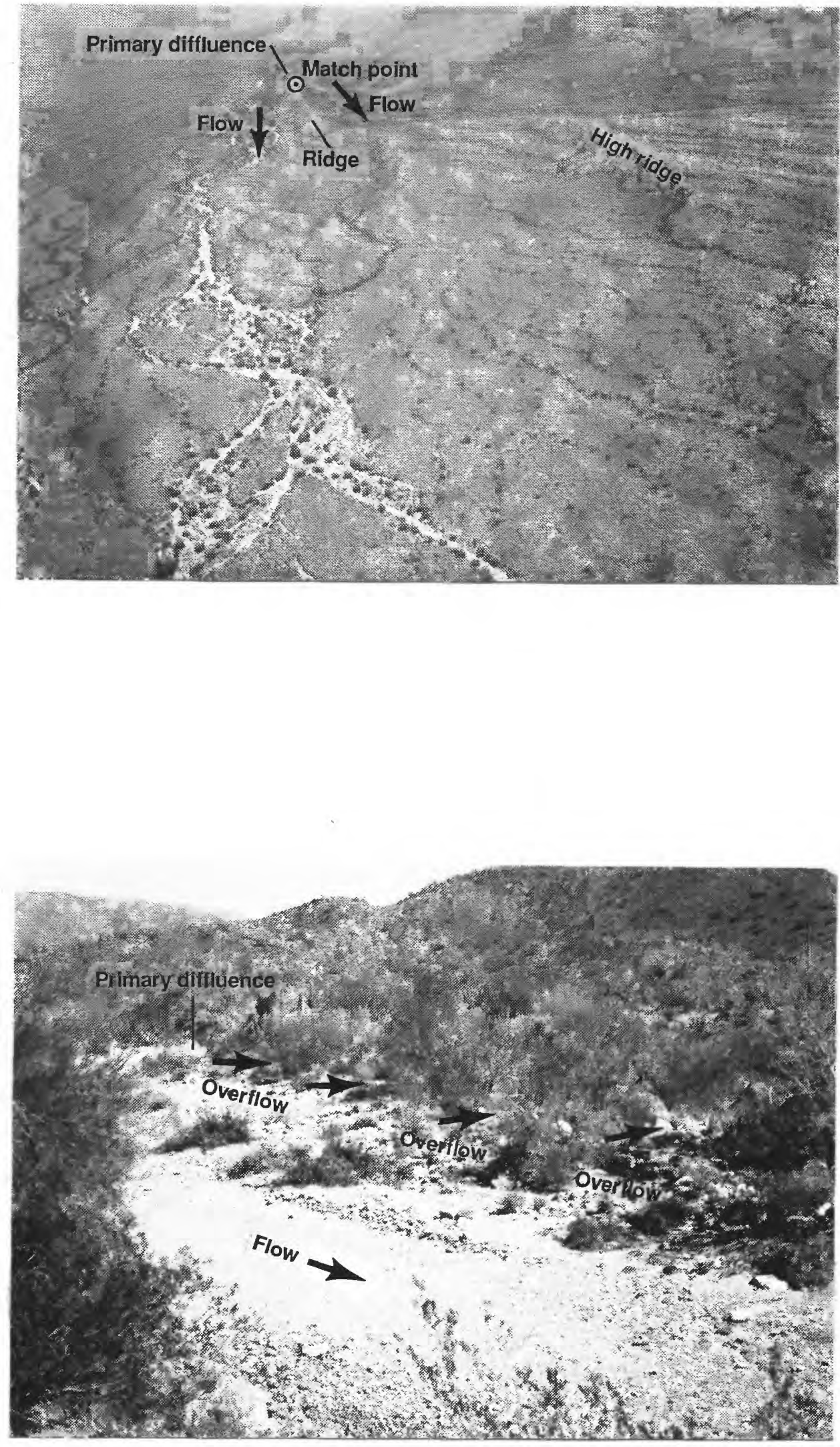

C. Looking upstream at the two distributary channels and the large area with high ridges between the channels from above the larger distributary channel. Some distributary flow is in the foreground of the channel to the left of the scene, but this flow is considered minor. In the middle and upper distributary-flow areas, the flow is separated by high ridges, and only two distinct distributary channels are present. Match point corresponds to match point on figures 2, 3A, and $3 B$.
$D$, Looking upstream at the larger channel where floodflow spills over the 4-foot-high left bank in the center of the scene.

Flgure 3. Continued. 


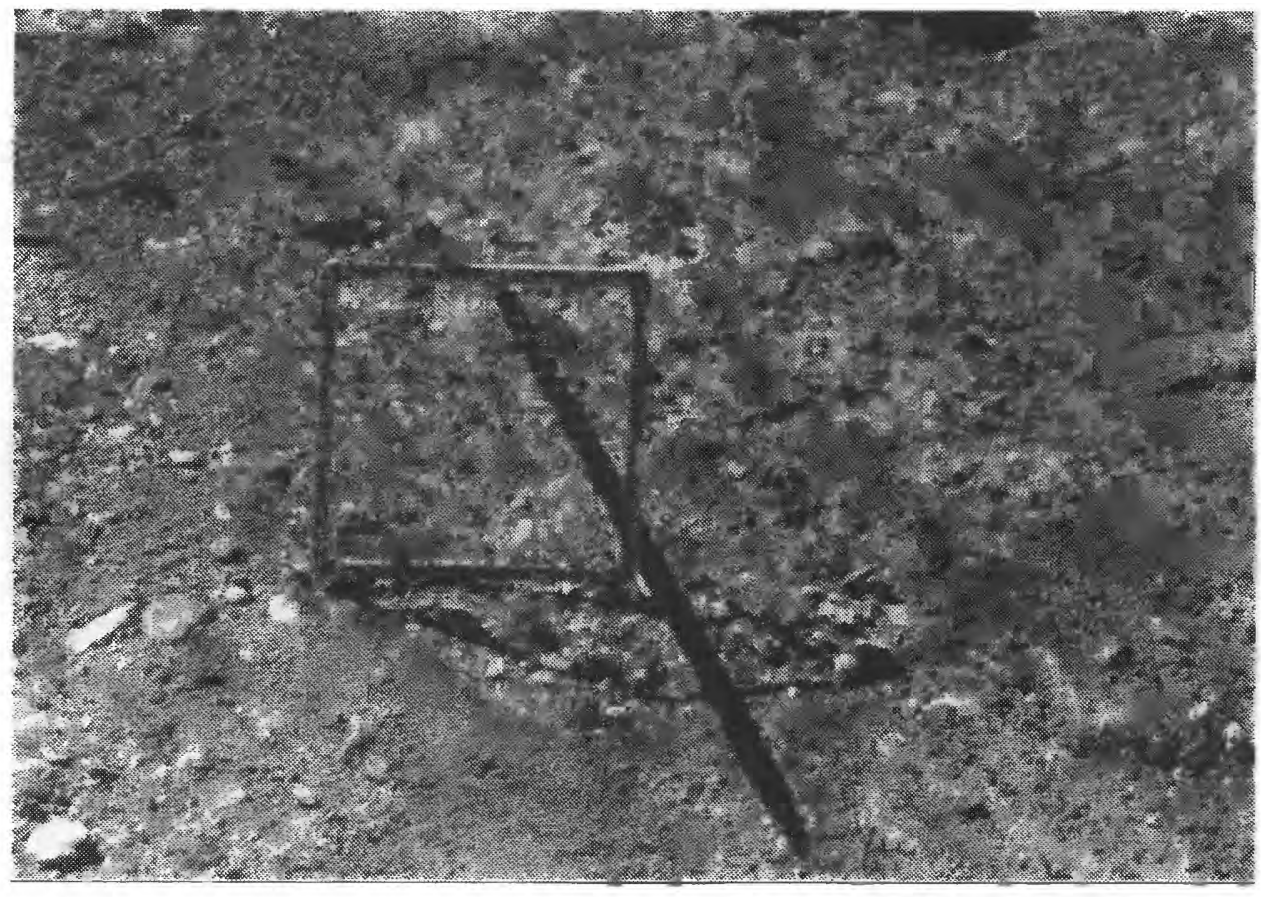

E, Looking south at the bed of the channel at the primary diffluence.

Figure 3. Continued. 

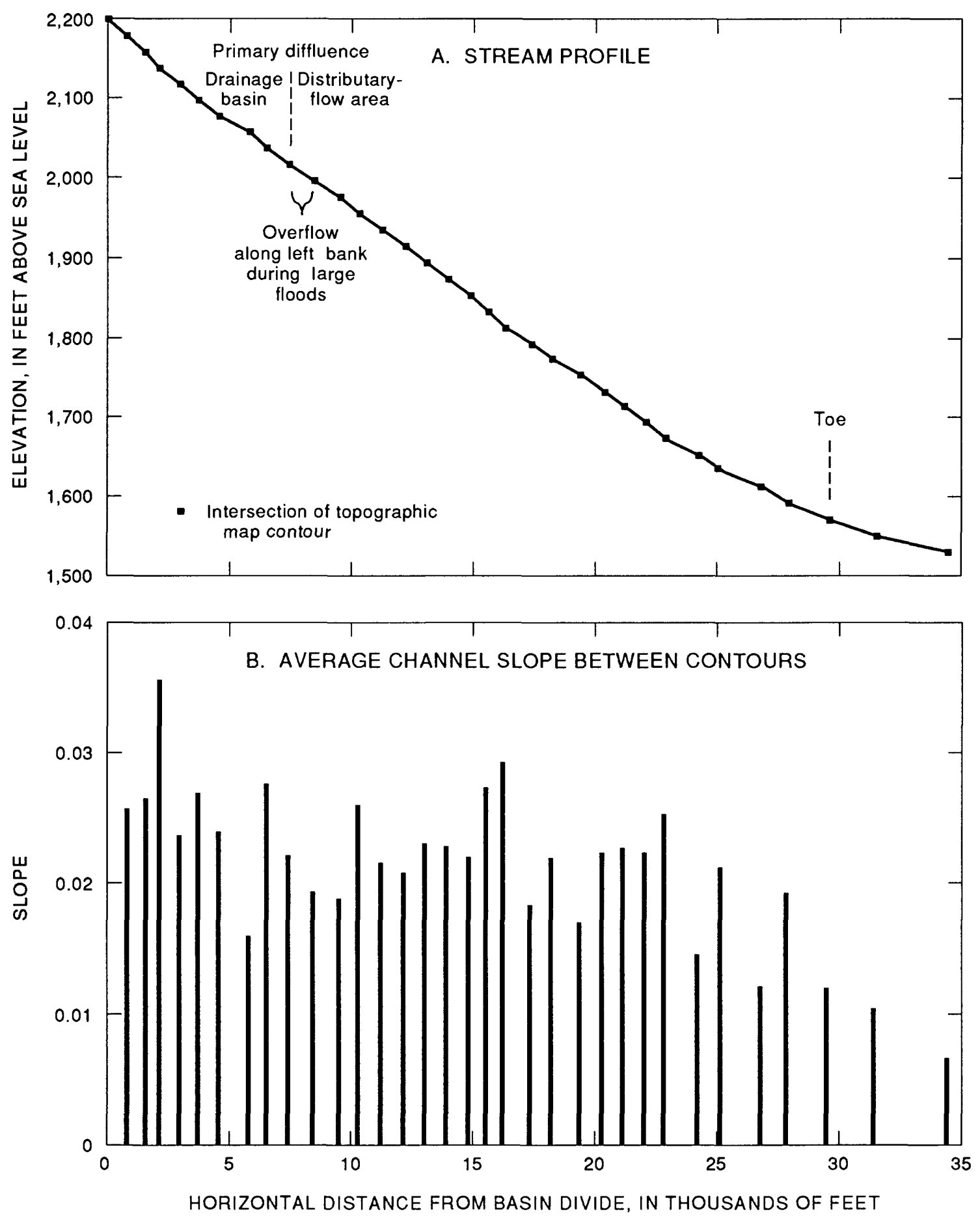

Figure 4. Stream profile and average slope of the west channel between topographic-map contours showing location of primary diffluence and toe of distributary-flow area for site 30. 
A

LEFT BANK

RIGHT BANK

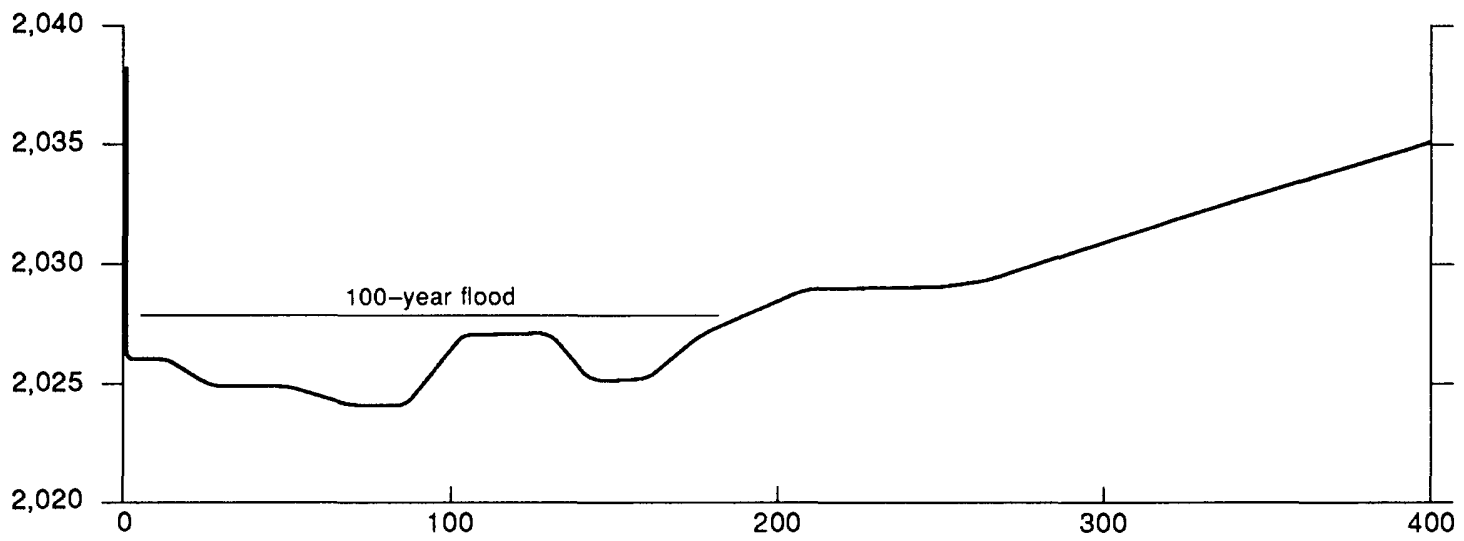

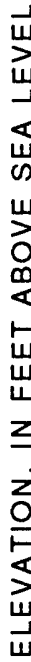
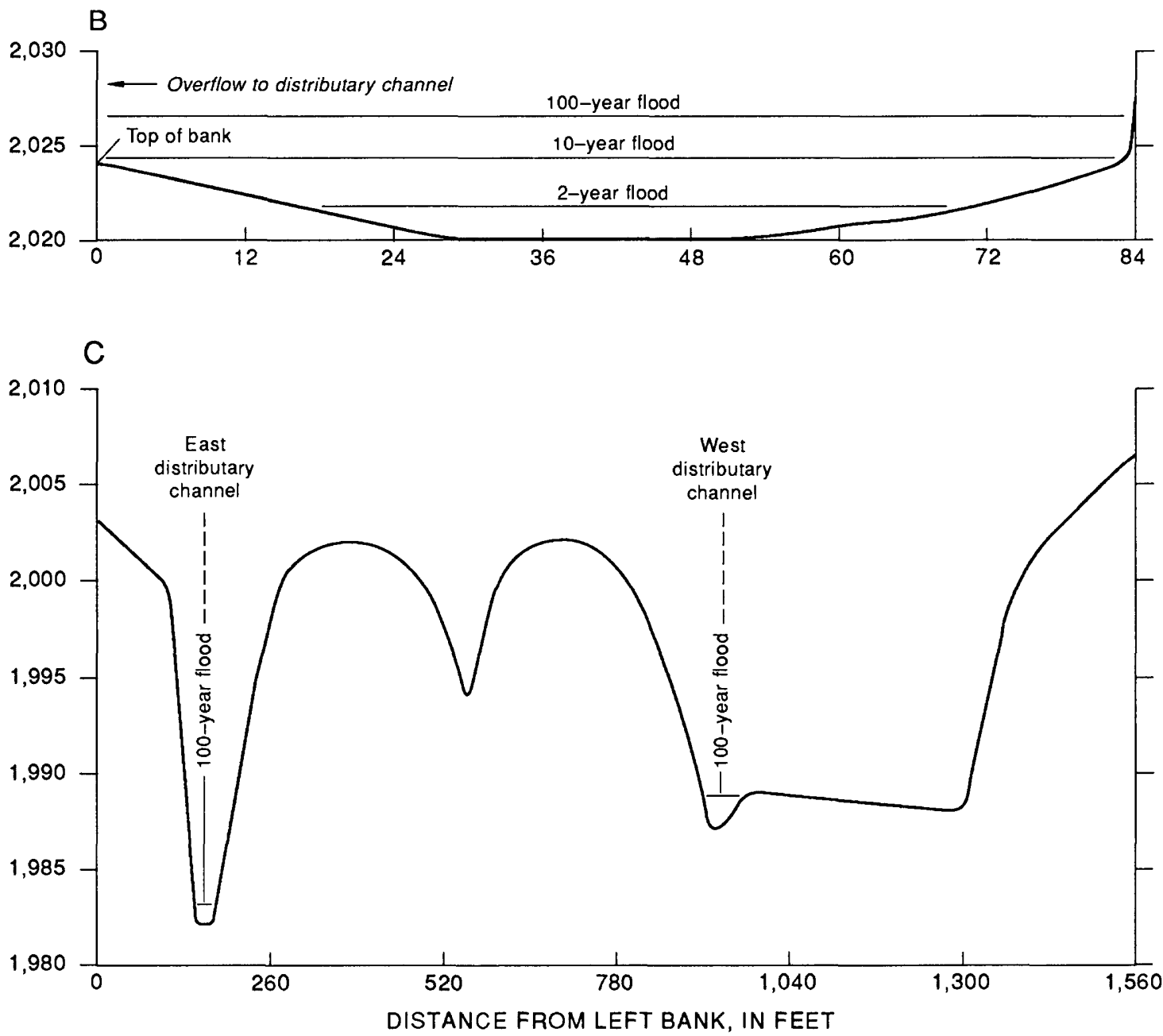

Figure 5. Cross sections of primary diffluence and upper distributary-flow area showing approximate level of selected T-year floods for site 30. A, Main channel of primary diffluence. $B$, Main channel at outflow. $C$, 2,000 feet below primary diffluence. 
Small areas of distributary flow are in the downstream reaches of the two major distributary channels. These small DFA's are within the estimated flood boundaries (fig. 2) but are too small to be considered in the overall classification of the type of DFA. On a large, general scale, the distributary flow is in two channels (fig. 2), but along each of the channels, small areas of different types of distributary flow occur (fig. 3C). The small DFA's are classified separately.

The flood-hazard degree of 2 for site 30 is much lower than the flood-hazard degree for nearby sites on the southern slopes of the Harquahala Mountains. The flood-hazard degree for site 29 to the west is 9 and for site 35 to the east is 10 (Hjalmarson and Kemna, 1991). The flood-hazard degree appears independent of general geographic location for DFA's in and near Maricopa County.

\section{Site 2}

The distributary channel system of site 2 , on a west-facing piedmont in northeastern Maricopa County, is used to show how floodflow divides, recombines, and generally remains within defined channels between most of the ridges of the DFA (flood-hazard degree of 6). The PD for site 2 (cross section A, fig. 6) that was defined previously (Hjalmarson and Kemna, 1991) included two large channels nearly $2,000 \mathrm{ft}$ apart. Upstream from the PD near the north boundary of section 13 and $0.75 \mathrm{mi}$ upstream from cross section $9 \mathrm{~A}$ (fig. 6), about 10 percent of the floodflow in the left channel divides into the right or north channel. Section 13 is in a transition zone between the pediment and alluvial plain, and, except for a few isolated pockets of alluvium where the flow divided, most of the area is pediment or pediment thinly covered by alluvium (Hjalmarson, 1978). Most of the surface material in section 14 downstream from cross section 9A is alluvial fill, and because some of the flow in the two large channels joined upstream, the PD was defined to include both of the large channels.

The flood-frequency characteristics at the PD were determined for each of the large channels using methods by H.W. Hjalmarson and B.E. Thomas (U.S. Geological Survey, written commun., 1992). The 100-year discharge for the left channel was determined from the regional relation on the basis of a drainage area of $3.79 \mathrm{mi}^{2}$ and a mean-basin elevation of about $2,710 \mathrm{ft}$. The discharge was $4,130 \mathrm{ft}^{3} / \mathrm{s}$, of which 10 percent or $410 \mathrm{ft}^{3} / \mathrm{s}$ was assumed (on the basis of a field inspection of channel conveyance) to leave the channel and enter the large channel on the right. A 100-year discharge of $2,900 \mathrm{ft}^{3} / \mathrm{s}$ (drainage area, $2.31 \mathrm{mi}^{2}$; elevation, $2,710 \mathrm{ft}$ ) was determined for the right channel. With the divided flow, the 100-year discharge for the left and right channels at the PD was 3,720 and $3,310 \mathrm{ft}^{3} / \mathrm{s}$, respectively. Using the same procedure, the 10-year peak discharge for the left and right channels at the PD was 700 and $640 \mathrm{ft}^{3} / \mathrm{s}$, respectively.

The distribution of peak flow in the distributary channels is based on the assumption that the joining of separated flood peaks is always at the peak discharge. The peak discharge is simply apportioned through the network of channel links by assuming that the flood peaks coincide at all the divides and joins. Attenuation effects are assumed to be offset by tributary inflow. The apportionment of flow is based on channel slope and conveyance using roughness coefficients (Thomsen and Hjalmarson, 1991). More precise hydraulic calculations to apportion flow at such sites seems unwarranted because during major floods, there may be critical and supercritical flow in some reaches of the defined channels and subcritical flow in other reaches that have larger roughness coefficients. On land adjacent to the defined channels, the flow is shallower and commonly encounters more obstructions such as desert bushes and cacti. The velocities of the flood-plain flow commonly are subcritical except where there are few cobbles, boulders, and the vegetation is sparse. Although floodflow follows defined paths along the defined channels between stable ridges, there may be a complex and changing mosaic of critical, supercritical, and subcritical velocities in the defined channels and on the adjacent flood plains. Also, the distribution of peak flow at the diffluences is imprecise for the wide-shallow floodflow. For such a complex system, watersurface-profile methods that balance energy gradients, such as the standard-step method, are considered unwarranted in areas with several 


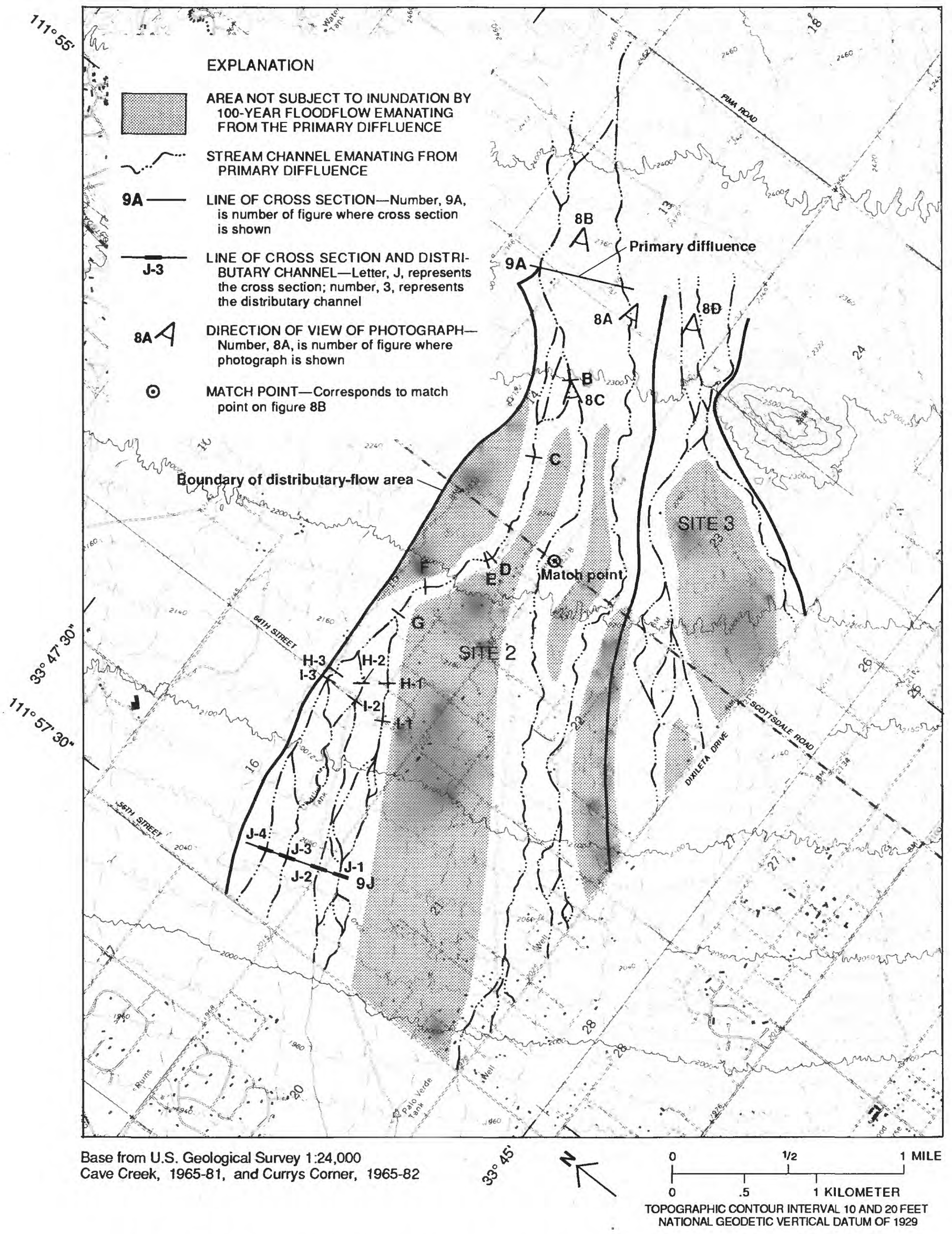

Figure 6. Topography, distributary channels, primary diffluence, larger ridge areas that are above the potential level of the 100-year flood, location and view angle of photographs, and location of cross sections for site 2.

16 Potential Flood Hazards and Hydraulic Characteristics of Distributary-Flow Areas in Maricopa County, Arizona 
distributary channels because of the computational complexity and limited potential precision of the computed distribution of discharge and watersurface levels for these conditions.

The location and extent of the PD of site 2 was difficult to precisely define because the loss of confinement of floodflow is gradual. Also, as mentioned previously, floodflow is in two channels at the PD, and floodflow in the left channel (fig. 6) divides and joins the right channel in the pediment area. The transition from pediment to alluvial plain is gradual with only a subtle change in channel slope where the PD was located (fig. 7). For a few hundred feet upstream from the PD, the slope is about 0.022 . At the PD, the slope changes to about 0.018 for a few hundred feet. Evidence of sediment deposition exists in the zone where the slope flattens (fig. 8A).

The two trees near the center of the channel at the PD are buried partially by deposited sediment (fig. 8A). The root collar of the trees is about 3 feet below the channel indicating the former level of the channel when the trees germinated. There are no visible scars on the bark that indicate damage from large floods. The absence of visible scarred bark does not necessarily indicate there has not been large floods because (1) the velocity and depth of the floodflow are not great because the floodflow spreads over a wide area and (2) scarring, if any, may be hidden below the bark. Channels that are filled with sediment may be more susceptible to lateral movement or channel avulsion during floodflow. The older trees in this area, like those shown in figure $8 \mathrm{~A}$, are commonly along the defined distributary channels.

If floodflow had remained confined in the two large channels (cross section A, figs. 6 and 9) upstream from the PD, then two DFA's corresponding to the two channels would have been selected. Because of the crossflow to the north channel, the definition of the DFA's is not clear. To demonstrate how the north channel and corresponding DFA could be considered a unique DFA, only the north channel is examined in detail.

North channel.-Floodflow of the 100-year flood is confined to a width of about $200 \mathrm{ft}$ from the PD to the first fork at the latitudinal center of section 14 (fig. 6) where about 30 percent of the floodflow is in two smaller channels to the right. At cross-section B, the width of flow is $112 \mathrm{ft}$ for a peak discharge of $2,320 \mathrm{ft}^{3} / \mathrm{s}$ (table 2). About 200 $\mathrm{ft}$ downstream from cross section $\mathrm{B}$, an estimated 10 percent of the 100-year discharge flowed over a low bedrock sill on the left side of the main channel. The estimated $230 \mathrm{ft}^{3} / \mathrm{s}$ remained confined in the small channel for about $2.5 \mathrm{mi}$ (fig. 6) where it becomes unconfined at a small diffluence near the south-central part of section 21 (distributary channels are not defined beyond Dixileta Drive).

Near the center of section 14 , the two large channels join upstream from cross section $C$ with a combined discharge of $3,080 \mathrm{ft}^{3} / \mathrm{s}$ in the 150 - to 200 -foot-wide channel and small flood plain. The first evidence of significant erosion at the consolidated banks is on the left side of cross section E starting at cross section D. The left bank of cross-section $E$ has moved shoreward a few tens of feet during the past few years. According to a local resident, the bank erosion probably resulted from damage by off-road vehicles. At cross section $\mathrm{D}$, the level of the 100 -year flood is about $1.5 \mathrm{ft}$ below the top of the channel banks and it is unlikely that floodflow will leave the confines of the channel between this location and cross section $G$ (fig. 6).

Downstream from cross section $G$, floodflow is unconfined for several hundred feet and can spread over a wide area. The apportionment of peak discharge at this diffluence is complex and is a good example for the use of channel conveyance to estimate the apportionment of peak discharge at diffluences. A visual examination of the width of the main channel of two sand channels just below the diffluence indicates about two-thirds of the discharge might be in the left channel. A large-scale topographic map (2-foot contours, $1: 1,200$ ) also indicates that about two-thirds of the peak discharge might be in the left main channel. Conveyance-slope computations that include the flood plains, however, indicate that about 36 percent of the flow approaching the diffluence would be in the flood plain on the right side of the main channel. At the diffluence, about a 200 -foot-wide area of the right-bank flood plain is inundated. The flood-plain flow only enters the right channel below the diffluence. The distribution of channel conveyance for the two channels and flood plains indicates that slightly less than half the peak discharge is in the left channel below the diffluence. Thus, because the effect of the different channel geometry upstream and downstream from 

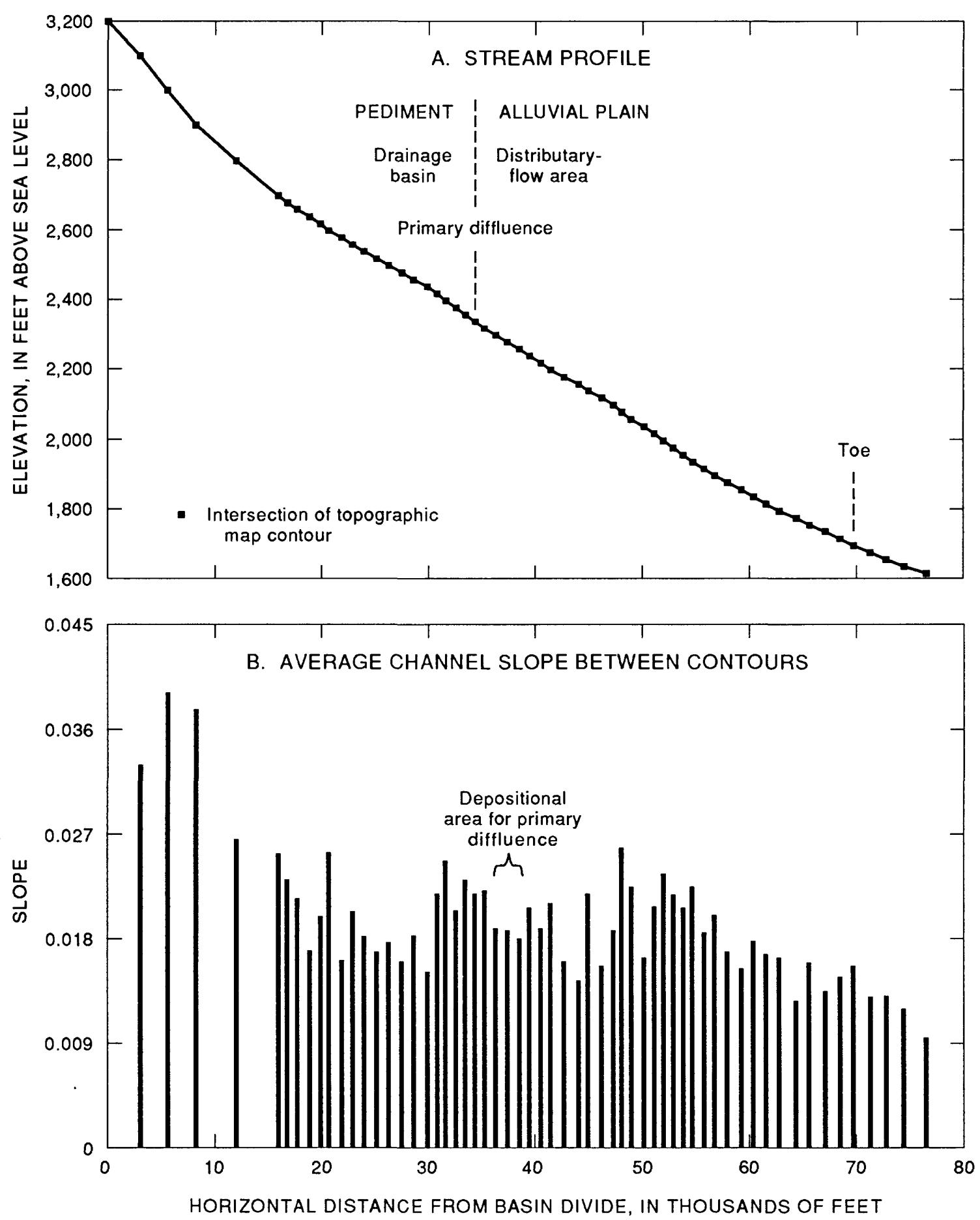

Figure 7. Stream profile and average slope of channel between topographic-map contours showing location of primary diffluence and toe of distributary-flow area for site 2 . 

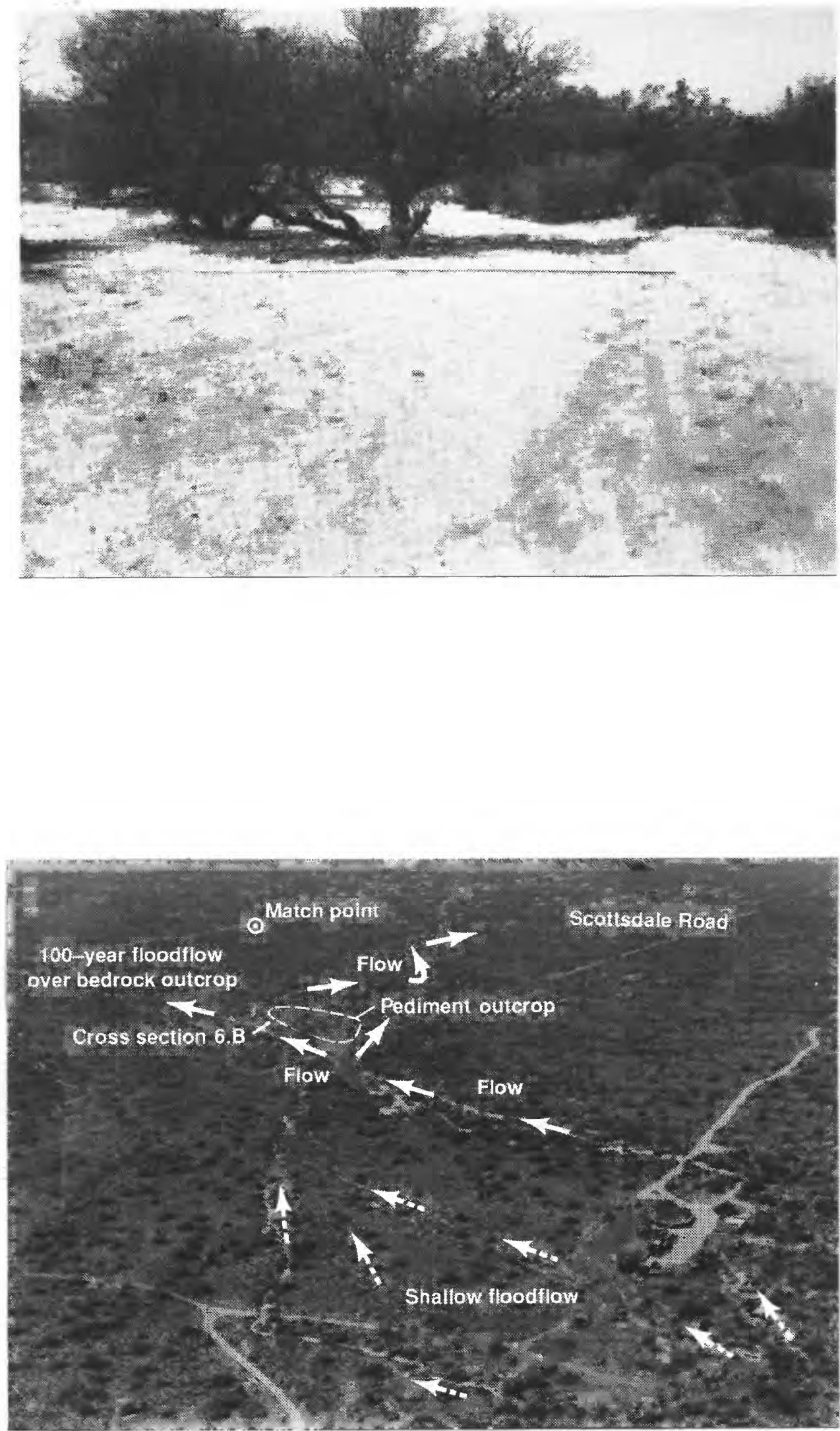

A, Looking downstream at the left channel downstream from the primary diffluence of site 2. The frame of the square grid is 1.5 -foot outside dimension on a side.
$B$, Looking downstream and west at the north channel of site 2. Two diffluences are upstream from the pediment outcrop where about 30 percent of the 100-year floodflow leaves the main channel to the right. About 200 feet downstream from cross section B (photograph $8 \mathrm{C}$ ) about 10 percent of the 100-year floodflow in the main channel overtops a bedrock outcrop that forms the left bank. Much of the land in the right foreground of the scene will be inundated by shallow 100-year floodwater. Match point corresponds to match point on figure 6 .

Figure 8. Site 2, primary diffluence, and distributary-flow area. 
c, Looking downstream at the main channel from cross section $B$. The width of floodflow widens in the reach shown and the deposited sand and gravel form a wide, flat channel bed. The trees and bushes commonly withstand the force of floodflow and greatly decrease the conveyance capacity of the channel. The dense vegetation along the channel acts to stabilize the channel location by resisting lateral erosion and by reducing the kinetic energy of floodflow. The frame of the square grid is 1.5 -foot outside dimension with an internal square of 1 foot on a side and grid spacing of 1 inch.

$D$, Looking downstream and southwest at distributary channels and old-fan remnants of site 3 on the south side of site 2. The two distributary channels are separated by the island of old-fan deposits that are above the level of the 100-year floodwater that emanates from above the primary diffluence. Local runoff on the old-fan deposits is drained by distributary channels that are not clearly visible in the scene. The vegetation on the old-fan deposits is less dense than the vegetation along the distributary channels and on the nearby recent alluvial deposits.
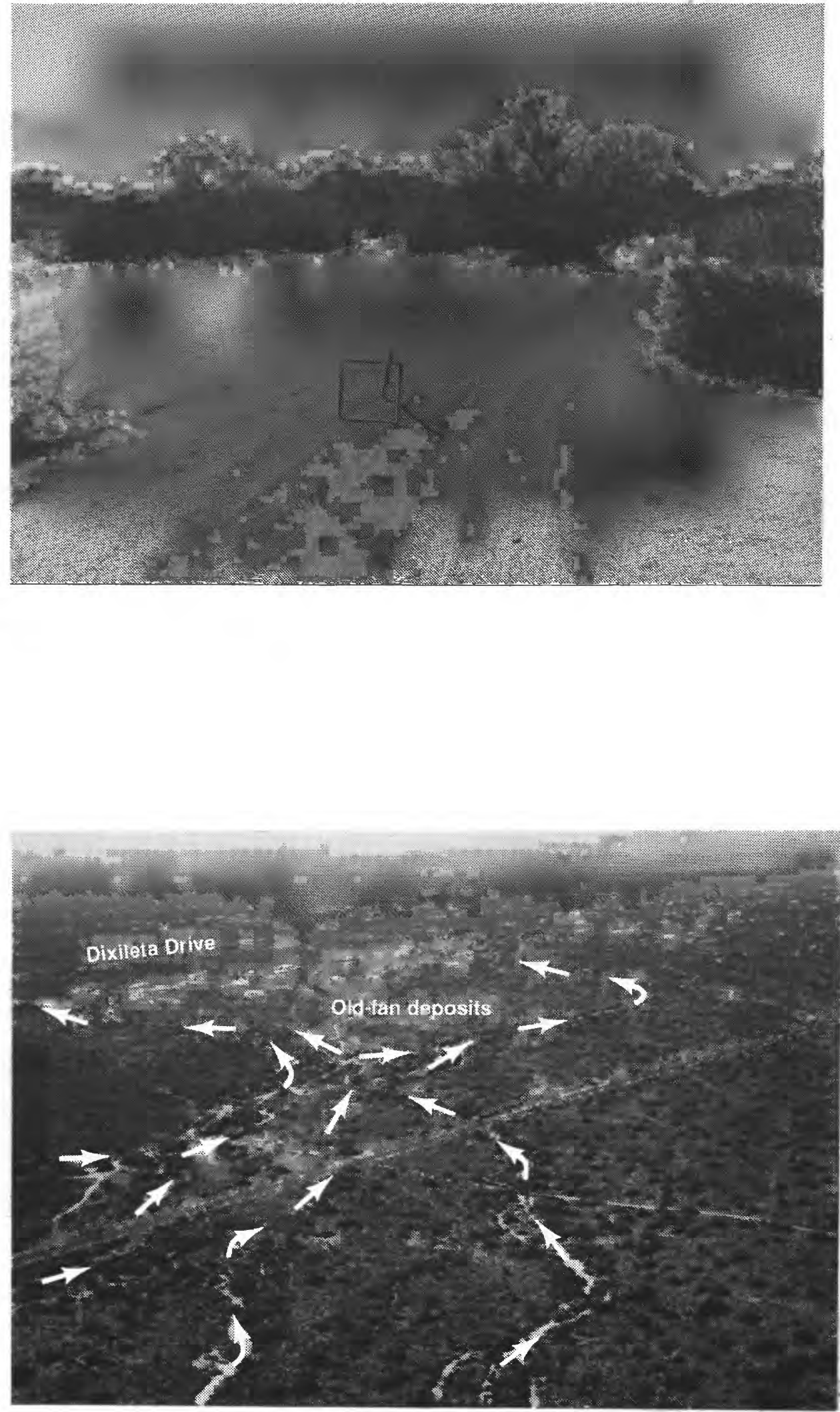

Figure 8. Continued. 
A

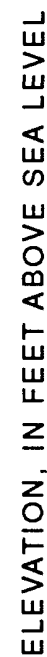

A

LEFT BANK

RIGHT BANK

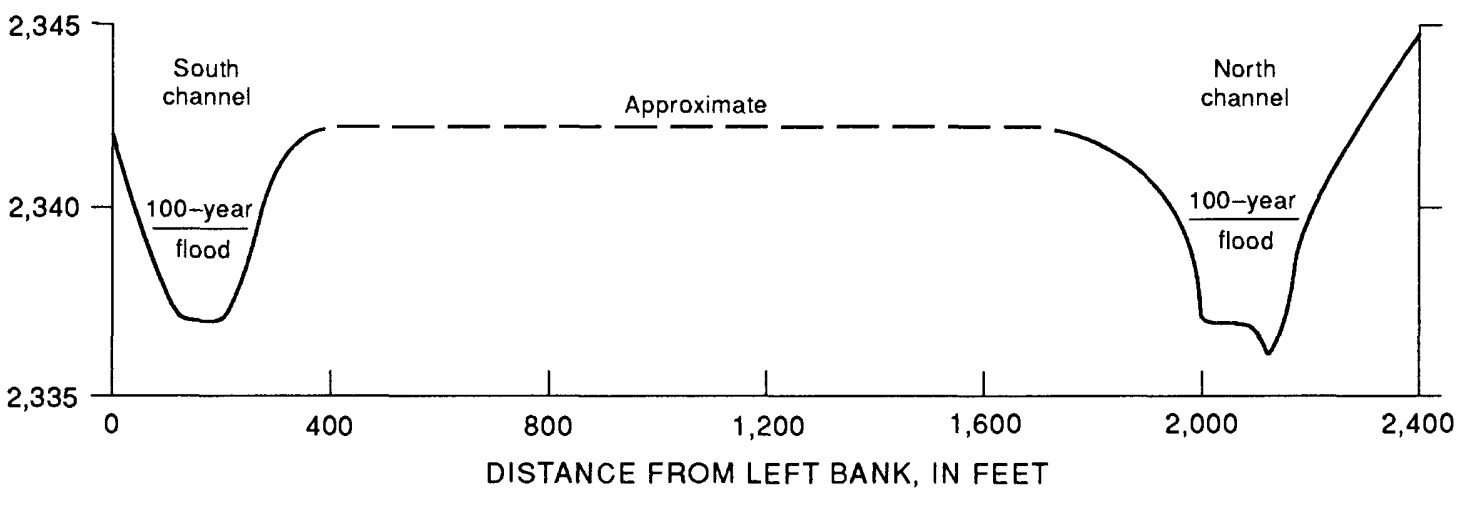

$B$

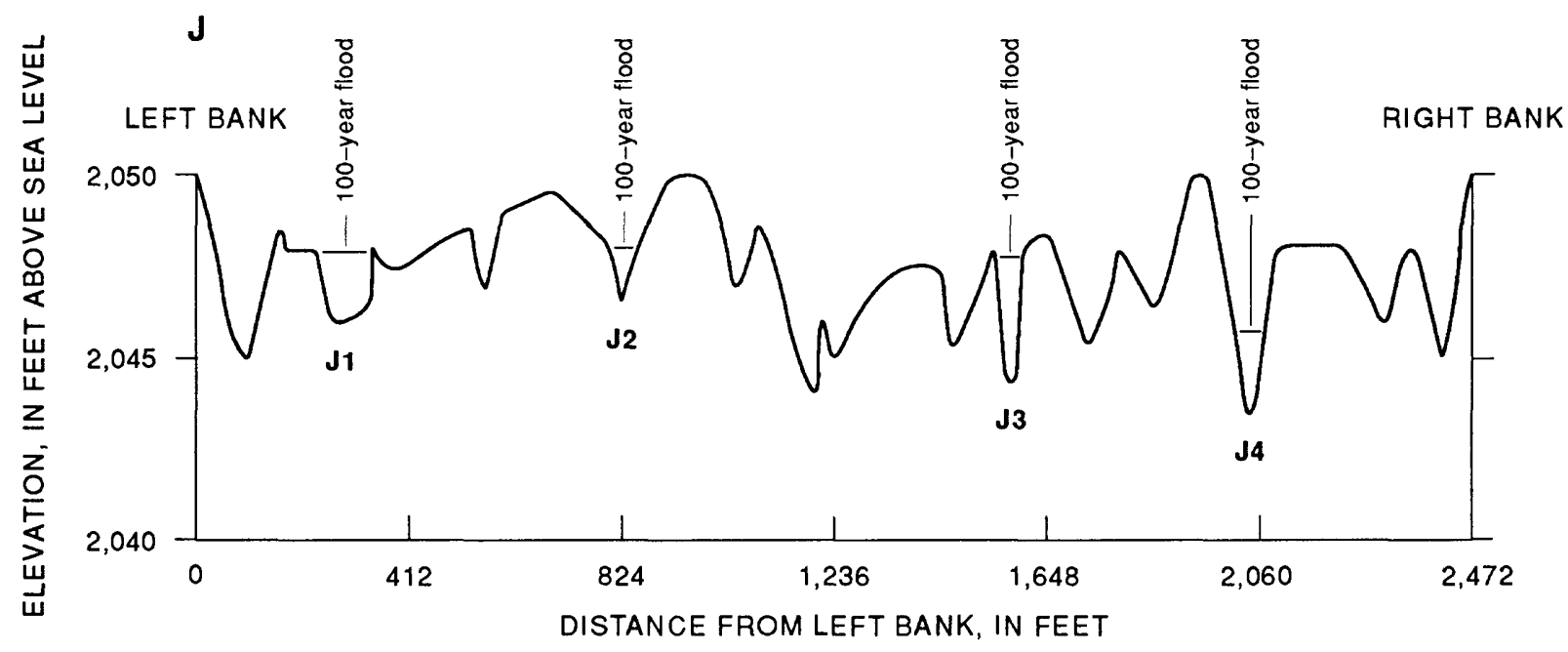

Figure 9. Cross sections of primary diffluence and upper distributary-flow area showing approximate level of the 100-year flood for site 2. A, Cross section A, primary diffluence. B, Cross section J, 14,070 feet below primary diffluence. 
Table 2. Characteristics of channel cross sections for 100-year flood at site 2

\begin{tabular}{|c|c|c|c|c|c|c|}
\hline $\begin{array}{l}\text { Cross section } \\
\text { (See figure 6) }\end{array}$ & $\begin{array}{l}\text { Station, in } \\
\text { feet }^{1}\end{array}$ & $\begin{array}{c}\text { Elevation of } \\
\text { water surface, } \\
\text { In feet }\end{array}$ & $\begin{array}{l}\text { Discharge, in } \\
\text { cubic feet } \\
\text { per second }\end{array}$ & $\begin{array}{l}\text { Velocity, } \\
\text { In feet per } \\
\text { second }\end{array}$ & $\begin{array}{l}\text { Width, } \\
\text { in feet }\end{array}$ & $\begin{array}{l}\text { Mean } \\
\text { depth, in } \\
\text { feet }\end{array}$ \\
\hline $\mathrm{A}$ & 0 & $2,339.23$ & 3,310 & 7.8 & 214 & 1.98 \\
\hline B & 2,500 & $2,299.54$ & 2,320 & 8.0 & 136 & 2.12 \\
\hline $\mathrm{C}$ & 4,500 & $2,259.35$ & 3,080 & 8.6 & 175 & 2.03 \\
\hline $\mathrm{D}$ & 7,250 & $2,213.00$ & 3,080 & 6.2 & 228 & 2.18 \\
\hline$E$ & 7,500 & $2,208.50$ & 3,080 & 5.5 & 274 & 2.03 \\
\hline $\mathbf{F}$ & 8,650 & $2,190.15$ & 3,080 & 6.5 & 230 & 2.06 \\
\hline G & 9,780 & $2,169.80$ & 3,080 & 5.3 & 471 & 1.23 \\
\hline $\mathrm{H}$ & 11,470 & ---------- & 23,080 & ${ }^{35} .6$ & 2393 & ${ }^{3} 1.40$ \\
\hline $\mathrm{H} 1$ & ------- & $2,139.55$ & 1,030 & 6.1 & 125 & 1.35 \\
\hline $\mathrm{H} 2$ & ------- & $2,139.75$ & 1,020 & 6.4 & 122 & 1.31 \\
\hline $\mathrm{H} 3$ & -------- & $2,139.90$ & 1,030 & 4.6 & 146 & 1.53 \\
\hline I & 12,170 & --.-- & ${ }^{2} 3,080$ & ${ }^{3} 5.9$ & ${ }^{2} 381$ & ${ }^{3} 1.37$ \\
\hline I1 & -------- & $2,119.60$ & 1,030 & 7.7 & 75 & 1.87 \\
\hline $\mathbf{I} 2$ & ------- & $2,125.30$ & 1,020 & 4.8 & 171 & 1.25 \\
\hline I3 & -------- & $2,128.15$ & 1,030 & 6.1 & 135 & 1.26 \\
\hline $\mathrm{J}$ & 14,070 & -------- & 23,080 & ${ }^{3} 6.7$ & ${ }^{2} 347$ & ${ }^{3} 1.32$ \\
\hline $\mathbf{J} 1$ & -.....-- & $2,047.90$ & 1,410 & 6.1 & 209 & 1.11 \\
\hline J2 & -------- & $2,047.50$ & 130 & 4.3 & 35 & .86 \\
\hline $\mathrm{J} 3$ & ------- & $2,047.75$ & 1,285 & 9.6 & 48 & 2.79 \\
\hline $\mathrm{J} 4$ & ------- & $2,045.80$ & 255 & 4.1 & 55 & 1.11 \\
\hline
\end{tabular}

${ }^{1}$ Downstream from primary diffluence.

${ }^{2}$ Total of cross sections

${ }^{3}$ Average of cross sections.

the diffluence is uncertain, an equal apportionment of peak discharge is used at the diffluence.

At the diffluence downstream from cross-section $\mathrm{G}$, the amount of floodflow in the two major channels is about the same. Downstream, some of the floodwater remains in the two channels while much of the floodflow spreads over the low banks on the several-hundred-foot-wide interfluvial area between the channels. About $1,600 \mathrm{ft}$ downstream from the diffluence, all of the floodflow is considered to be in three large channels (cross sections $\mathrm{H} 1-\mathrm{H} 3$, fig. 6) because the transverse slope of the inundated land is large in relation to the channel slope and generally is toward the three channels. The land between the two major channels from the diffluence to about $1,500 \mathrm{ft}$ downstream probably would be inundated by the 100-year flood. Flow paths in the area are difficult to predict as the potential width of inundated land increases from about $350 \mathrm{ft}$ at the diffluence to about $1,200 \mathrm{ft}$ where most, if not all, of the floodflow is confined to the three large channels at station $11,400 \mathrm{ft}$, which is $70 \mathrm{ft}$ upstream from cross section $\mathrm{H}$ (table 2 and fig. 6). At cross sections $\mathrm{H} 1$, $\mathrm{H} 2$, and $\mathrm{H} 3$, the peak discharge of the 100 -year flood is confined to the three large channels in about equal parts.

Downstream from cross sections I1-I3, there are several forks and joins; floodflow is unconfined in a few small areas downstream from 
diffluences. At cross sections $\mathrm{J} 1-\mathrm{J} 4$, most of the flow is in four channels; disproportionate amounts of discharge are determined by the apportionment of peak discharge at the several forks (table 2). The combined capacity of the four channels greatly exceeds the total discharge of the 100-year flood; however, the capacity of the channel at cross section $\mathrm{J} 1$, for example, is about equal to the 100 -year discharge. Some of the floodflow that emanates from the PD may be in other defined channels near cross section J1 (fig. 6). The potential flood hazard in the nearby channels is mostly related to local runoff; however, because some of the flow paths for small amounts of floodflow that emanate from the PD are uncertain, there is a chance that some of this floodwater would be in the nearby channels. Upstream from cross section $J$, there are a few residential structures in major distributary channels that could cause changes in the flow paths.

Downstream from 56th Street, the flood channels are not defined for this study (fig. 6). The distribution of floodflow for this area to Cave Creek, about $5 \mathrm{mi}$ downstream from 56th Street, can be estimated using the channel-conveyance method. The channels are more entrenched near Cave Creek, which is the base-level stream.

Throughout the study area, stream-channel locations generally appear stable and show little evidence of lateral movement of banks. Typically, floodflow is confined in the defined channels and adjacent flood plains. Most of the ridges separating the channels are above the level of the 100-year flood. Much of the unconfined flow is in low-lying areas between distributary channels downstream from channel forks. The center two-thirds of section 21 , the northwestern part of section 22 , and the south one-fifth of section 15 (fig. 6) are not likely to be subject to floodflow that originates upstream from the PD. Potential flooding in this area is from local rainfall and runoff.

Throughout the DFA, many small stream channels are separated by defined ridges that are crusted by calcrete deposits. Many of the channels are cut 2 to $4 \mathrm{ft}$ deep and have a spacing of 100 to $400 \mathrm{ft}$ between the channels (fig. 9B). The slope of the land transverse to the stream channels is large; and local, unconfined flow generally re-enters defined channels short distances downstream from the unconfinement. In many places, the transverse slope of the land surface along both tributary and distributary channels is greater than the general slope of the DFA. The resultant slope of the land surface, which is the vector addition of the transverse and general slope, is commonly only a few percent more than the general slope of the land.

The width of the 100-year flood generally increases from the PD to cross section $G$ where floodflow is unconfined (table 2). Downstream from cross section $G$, the sum of the widths of floodflow in the several channels decreases a few tens of feet or perhaps becomes fairly constant. In other studies, the sum of floodflow widths for networks of distributary channels has been observed to be approximately constant (DMA Consulting Engineers, 1985, tables A3 and A4). The mean depth of floodflow decreases at cross section $G$ relative to upstream cross sections and seems to become constant at about two-thirds of the mean depth of the upstream cross sections. Estimated mean velocity did not appear to change downstream from the large diffluence at cross section $\mathrm{G}$.

In summary, the method used to estimate flood levels was based on the channel and hydraulic conditions of site 2 . The paths of floodflow, as defined by the network of distributary and tributary channels, of the DFA are confined by erosion-resistant banks. The beds of the sand channels, however, scour and fill during floodflow and estimates of flood levels and boundaries are less precise than the channels with stable beds. The apportionment of floodflow to distributary channels below diffluences also is affected by the amount of scour and fill in the channels above and below the diffluences. Because of the unstable nature of the channel beds and the large number of forks and joins, the use of the standard-step method to compute water-surface profiles was not appropriate. The standard-step method can produce reliable water-surface profiles but many cross sections are needed, and the computations are complicated by many forks and joins. The standard-step method was not considered an effective means of computing the flood levels because of the uncertain apportionment of floodflow in the many distributary channels. Until two-dimensional or one-dimensional models of interconnected channels (Schaffranek and others, 1981) are shown to model the flow on stable DFA's 
with reasonable computational simplicity and accuracy, the above conveyance-slope method is considered a satisfactory solution to this complex problem.

\section{Site 39}

Site 39 is on the western slopes of the White Tank Mountains in central Maricopa County. Site 39 was assigned a flood-hazard degree of 8 . The location of most of the sand channels appears stable, but most of the interfluvial areas can be overtopped by the 100-year flood. The width of the DFA increases gradually to the toe (fig. 10), and the slope of the DFA is fairly uniform (fig. 11). Only a small depositional mound is downstream from the PD. The DFA is inset in old-fan deposits (fig. 12A); boundaries are defined by distinct differences in vegetation density, soil color, and drainage texture (fig. 12B). The level of the 100-year flood is about $5 \mathrm{ft}$ below the top of the left bank at the PD (fig. 13A), the banks at the PD are cemented old-fan remnants, and the surface rocks are covered with iron oxide (fig. 12C). A light coating of desert varnish is on some of the stones at the top of the banks at the PD. The channel bed is composed of sand and gravel with scattered cobbles and boulders (fig. 12D). About $500 \mathrm{ft}$ downstream from the $\mathrm{PD}$, the channel widens abruptly, and distributary flow occurs downstream (fig. 12E). About $1,700 \mathrm{ft}$ downstream from the $P D$, floodflow is in four distinct distributary channels separated by three ridges that are from 4 to $10 \mathrm{ft}$ above the channel beds (fig. 13B). Small high ridges like those shown in figure 13B are not defined in figure $12 \mathrm{~A}$.

Two large ridge areas that are above the level of the 100 -year flood (1) are undissected by stream channels, (2) have distinctly less vegetation than the surrounding DFA, and (3) have slightly darker soils. A few other high-ridge areas are above the level of the 100-year flood; however, some of the ridges can be overtopped.

The difference between stable and unstable paths of flow can be observed by comparison of the upper DFA's of sites 36 and 39. Site 36 is also on the western slopes of the White Tank Mountains and is about $2.5 \mathrm{mi}$ to the southeast of site 39 . The flow paths in the upper part of the DFA of site 36 are rather uniformly distributed across the DFA (fig. 14). Few interfluvial ridges are in the upper DFA of site 36. The flood-hazard degree of site 36 is 10 , and flood water of the 100-year flood can inundate any part of the DFA.

\section{Site 6}

The DFA of site 6, which is on the western slopes of the McDowell Mountains, has four distinct areas of flood hazard. The largest area includes the western one-half of the total DFA where floodflow from the PD fills many channels that divide and combine (fig. 15) and includes most of the DFA that was defined by Hjalmarson and Kemna (1991). The second area is along the east side of the DFA where some flow that passes the PD overtops the left bank of the main channel and becomes separated (figs. 15, 16A, and 16B). Approximately $0.75 \mathrm{mi}$ downstream, the separated flow to the east is constricted at the toe of the mountain along the left bank where there is tributary inflow from a small mountainous basin. Downstream, the floodflow is confined except near the center of section 20 (fig. 15) where there are several small unstable channels. Tributary inflow occurs along the separated channel from the mountainous basins to the east. At the north side of section 29 , most of the potential flood hazard appears to be related to the tributary flow. Between the areas inundated by the main and overflow channels is a small third area of old-fan remnants (figs. 15 and 16B) above the level of the 100 -year flood in the DFA. The fourth area is in a "shadow" downslope from the old-fan remnants (fig. 16C). This area is mostly tributary channels with a few small distributary channels, which may carry floodflow that emanates from the PD. Most upslope floodflow that passed the PD is diverted to the right and left of the "shadow" area by the old-fan remnants.

The potential flood hazard of the four areas downstream from the PD of site 6 are markedly different. The large DFA on the west has a flood-hazard degree of 9 or 10 because most of the ridges will be overtopped, some of the flow paths may be stable, and several of the flow paths can change. A few of the flow paths appear stable 


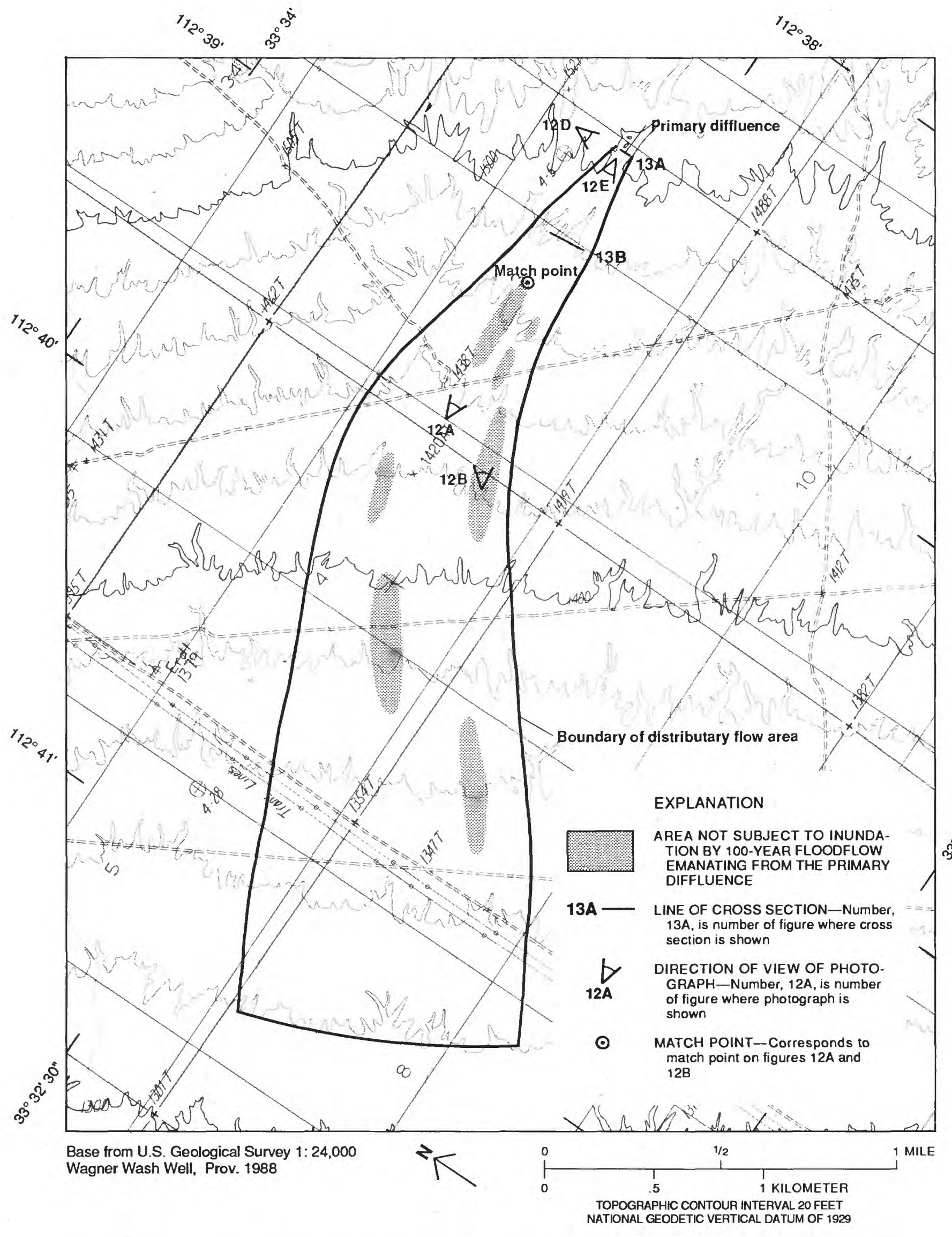

Figure 10. Topography, distributary channels, primary diffluence, larger ridge areas that are above the potential level of the 100-year flood, location and view angle of photographs, and location of cross sections for site 39. 

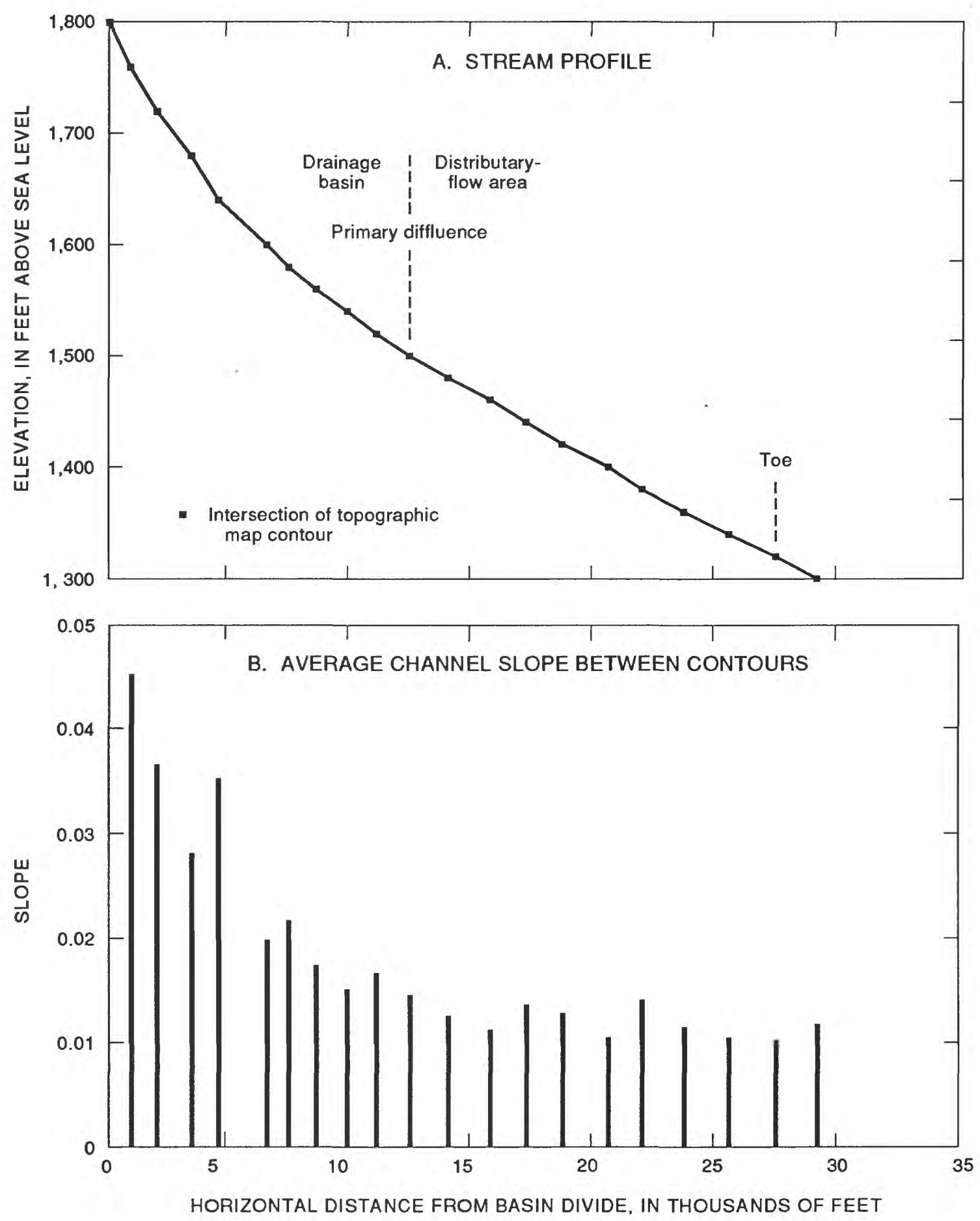

Figure 11. Stream profile and average slope of channel between topographic-map contours showing location of primary diffluence and toe of distributary-flow area for site 39. 

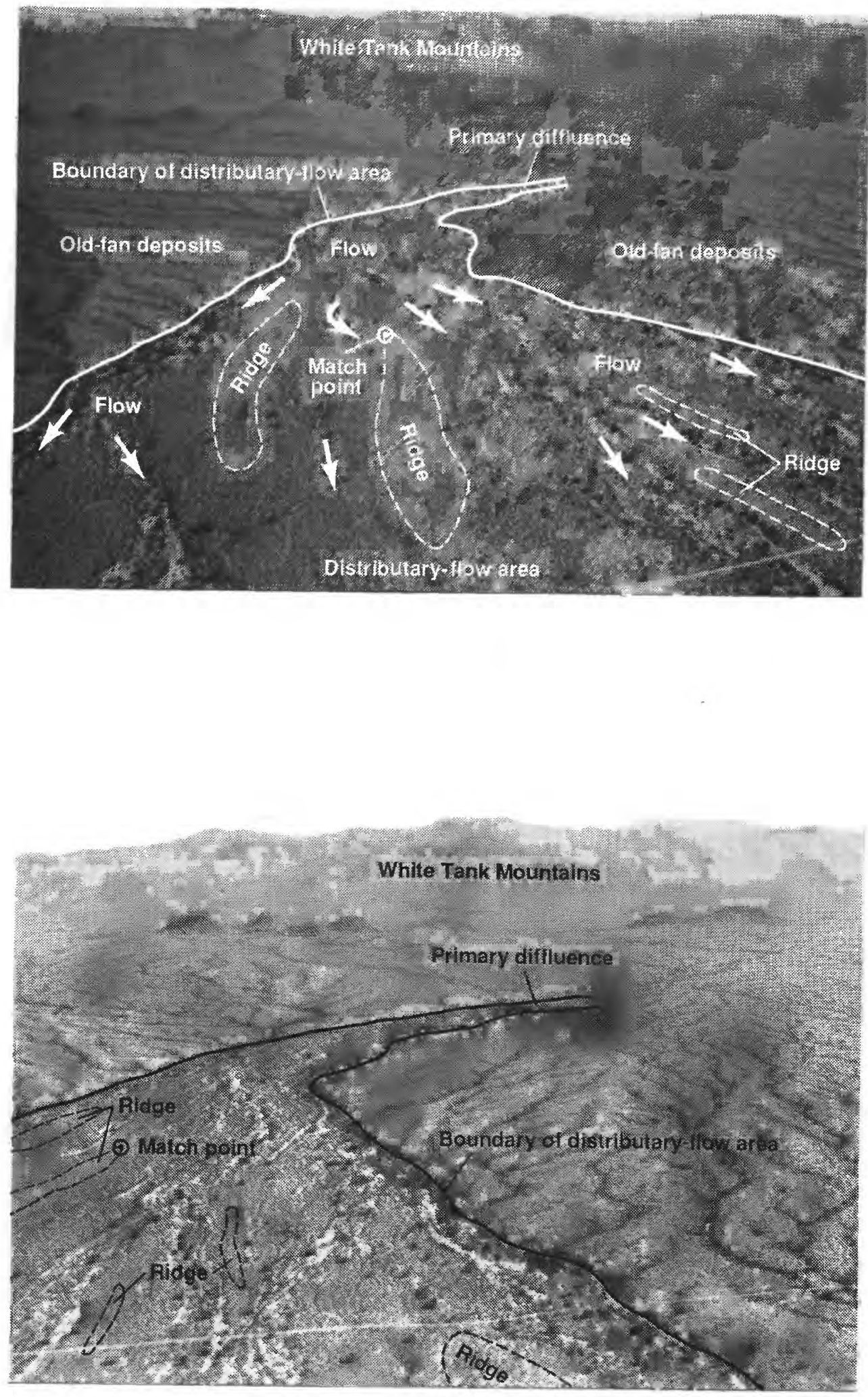

$A$, Looking upstream and northeast at the upper distributary-flow area and primary diffluence. The camera is above the lower middle of the distributary-flow area about 5 miles to the southwest of the head of the basin at the crestline of the White Tank Mountains in the left background. Two interfluves with ridges are above the level of the 100-year flood in the center foreground. Except for the two high-ridge areas and other smaller high-ridge areas that are not defined (figure 13B, for example), most of the distributary-flow area appears to have been inundated by flood. flow. Match point corresponds to match point on figures 10 and $12 B$.

$B$, Looking upstream and northeast at the left-bank side of the distributary-flow area where the paths of flow, as indicated by the location of the lightcolored channels, appear chaotic. A distinct difference in the size and density of vegetation occurs on the distributary-flow area and the adjacent land. The boundary between the distributary-flow area and the adjacent tributary-flow areas on the old-fan deposits is distinct. This boundary is less obvious in other areas of southwestern Arizona where the vegetation cover is more dense. Match point corresponds to match point on figures 10 and $12 \mathrm{~A}$.

Figure 12. Site 39, primary diffluence, and distributary-flow area. 
C, Looking down at overturned stone on string grid with oxidation on bottom of stone located at top of the right bank at the primary diffluence. The iron oxide is found on the bottoms of nearly all stones along the top of both banks at the primary diffluence. The frame of the square grid is 1.5 -foot outside dimension with an internal square of 1 foot on a side and grid spacing of 1 inch.

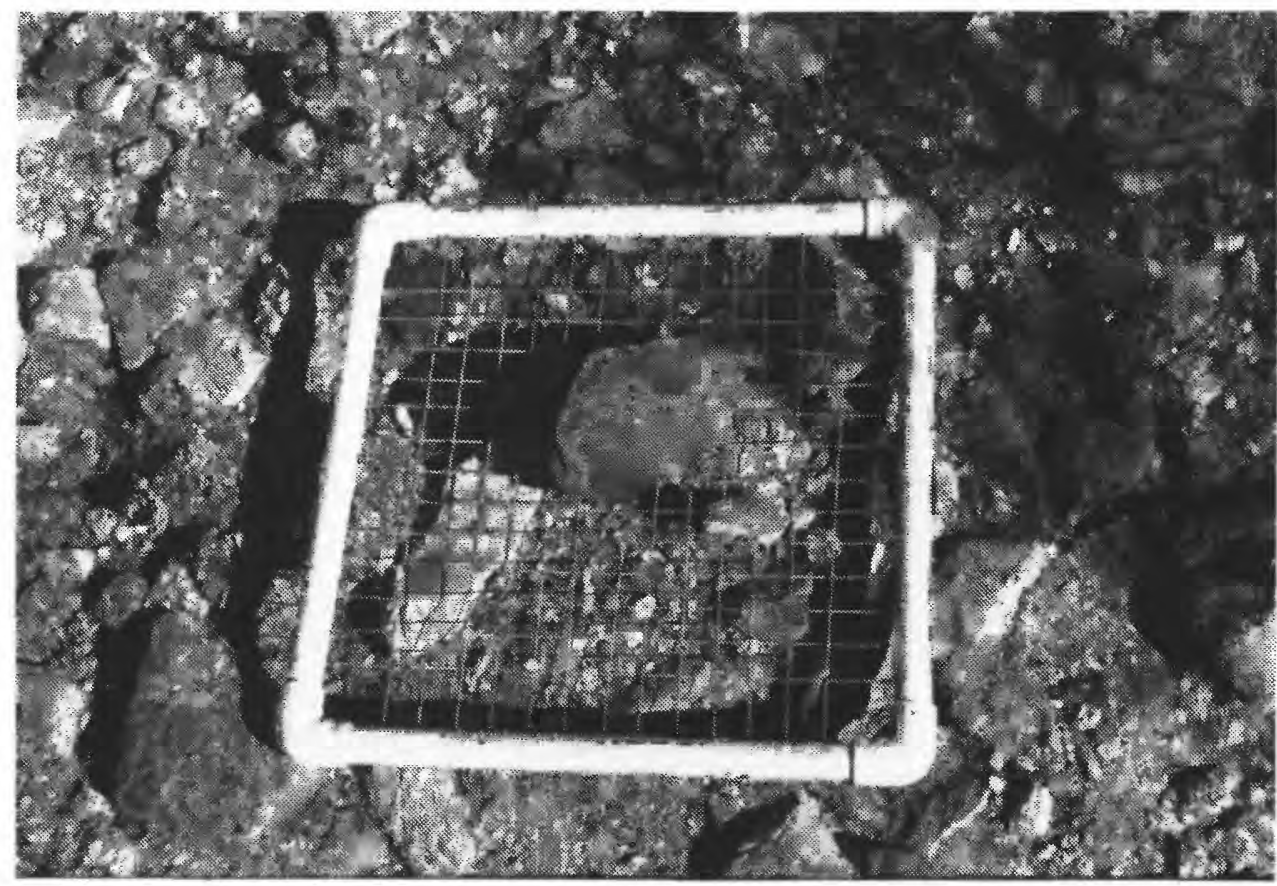

$D$, Looking southwest and across at left bank of primary diffluence from near top of right bank. The level of the 100-year flood is about 3 to 4 feet above the channel bed. The banks are cemented old-fan deposits that are resistant to erosion by floodflow. The frame of the square grid is 1.5 -foot outside dimension on a side.

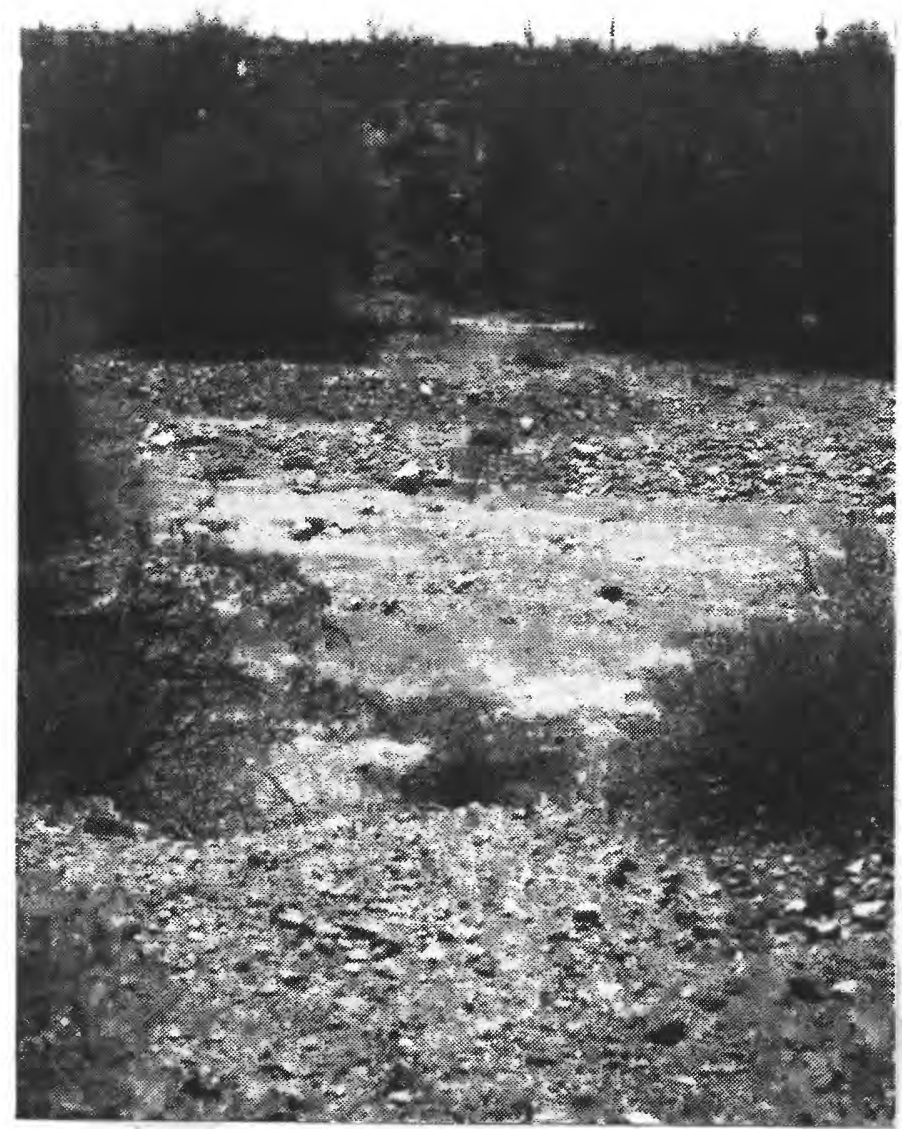

Figure 12. Continued. 


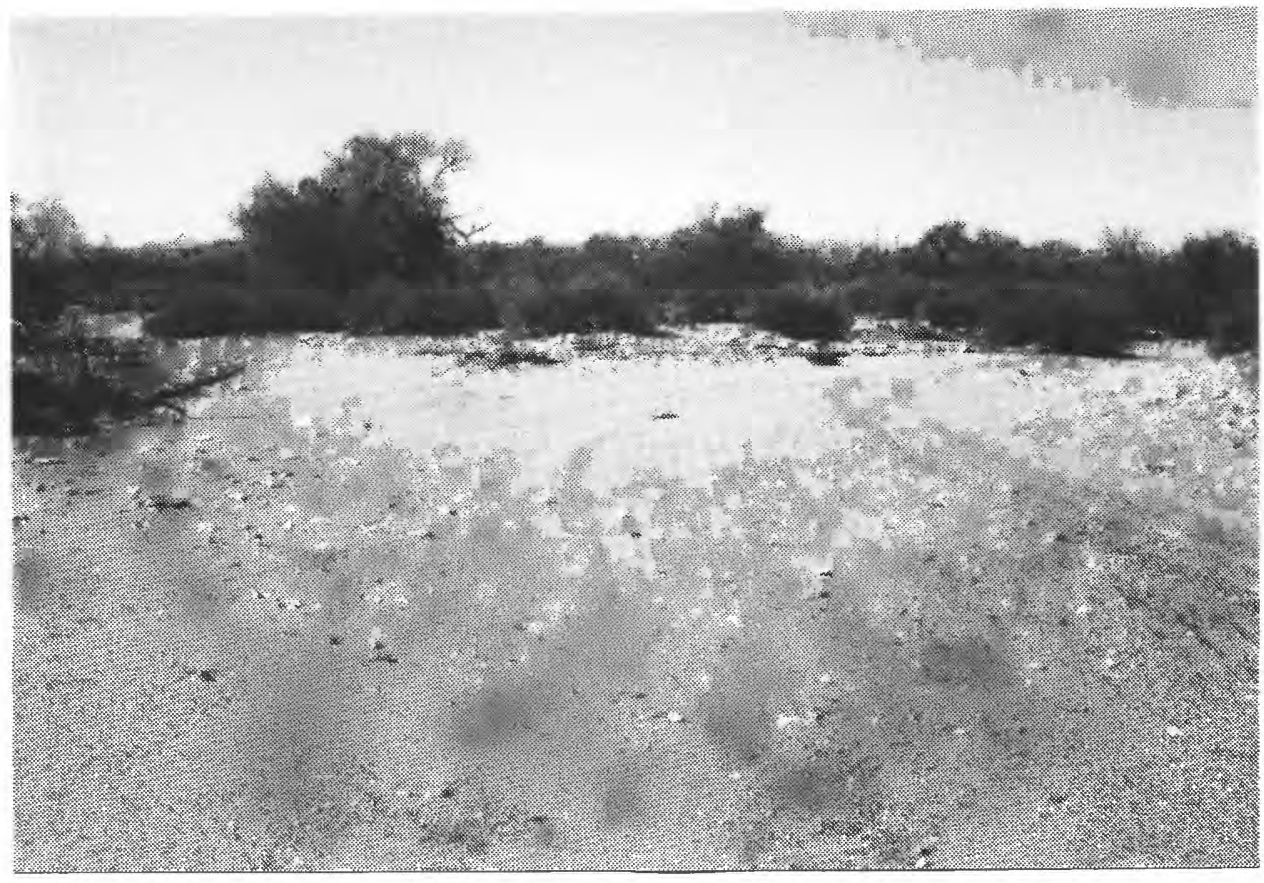

$E$, Looking downstream from the center of the channel about 500 feet downstream from the primary diffluence where the floodflow spreads over a wide area. The largest channel is to the right, and floodflow is unconfined beyond this point. Recent deposition across this aggrading area is apparent, and the distribution of floodflow in the defined distributary channels downstream is controlled by the amount and distribution of deposited material in this area. The frame of the square grid is 1.5 -foot outside dimension on a side.

Figure 12. Continued. 
A

LEFT BANK

RIGHT BANK

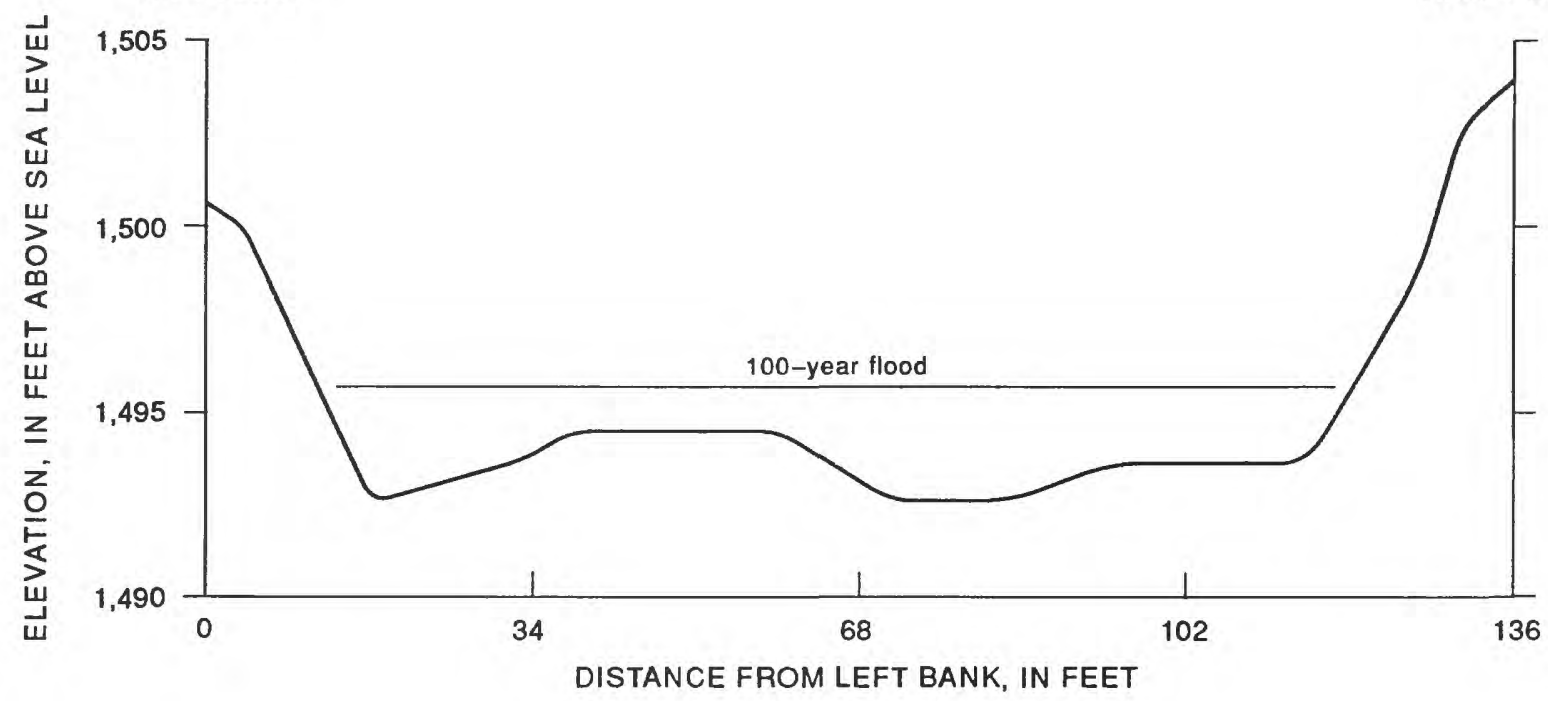

B

LEFT BANK

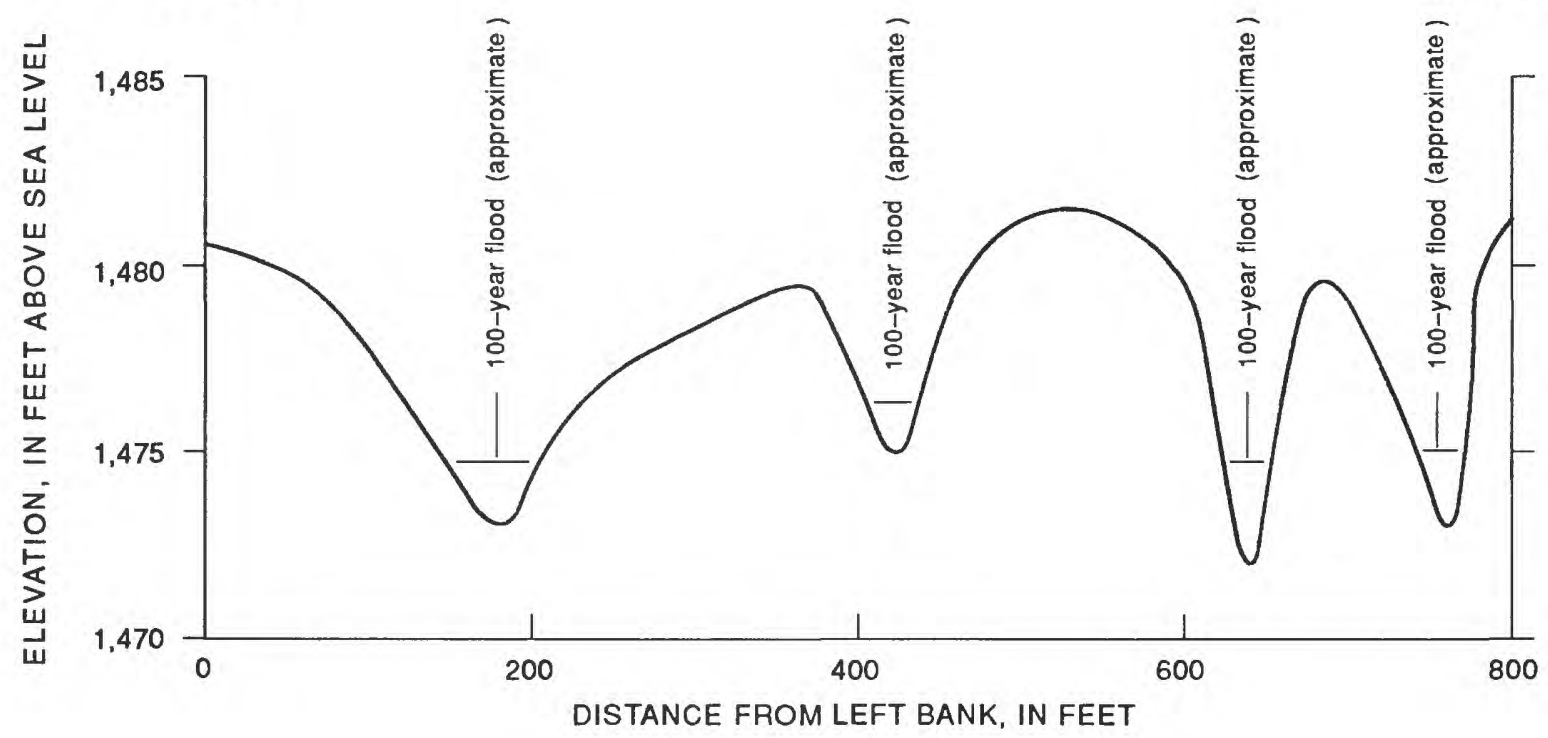

Figure 13. Cross sections of primary diffluence and upper distributary-flow area showing approximate level of the 100-year flood for site 39. A, primary diffluence. $B, 1,700$ feet below primary diffluence. 


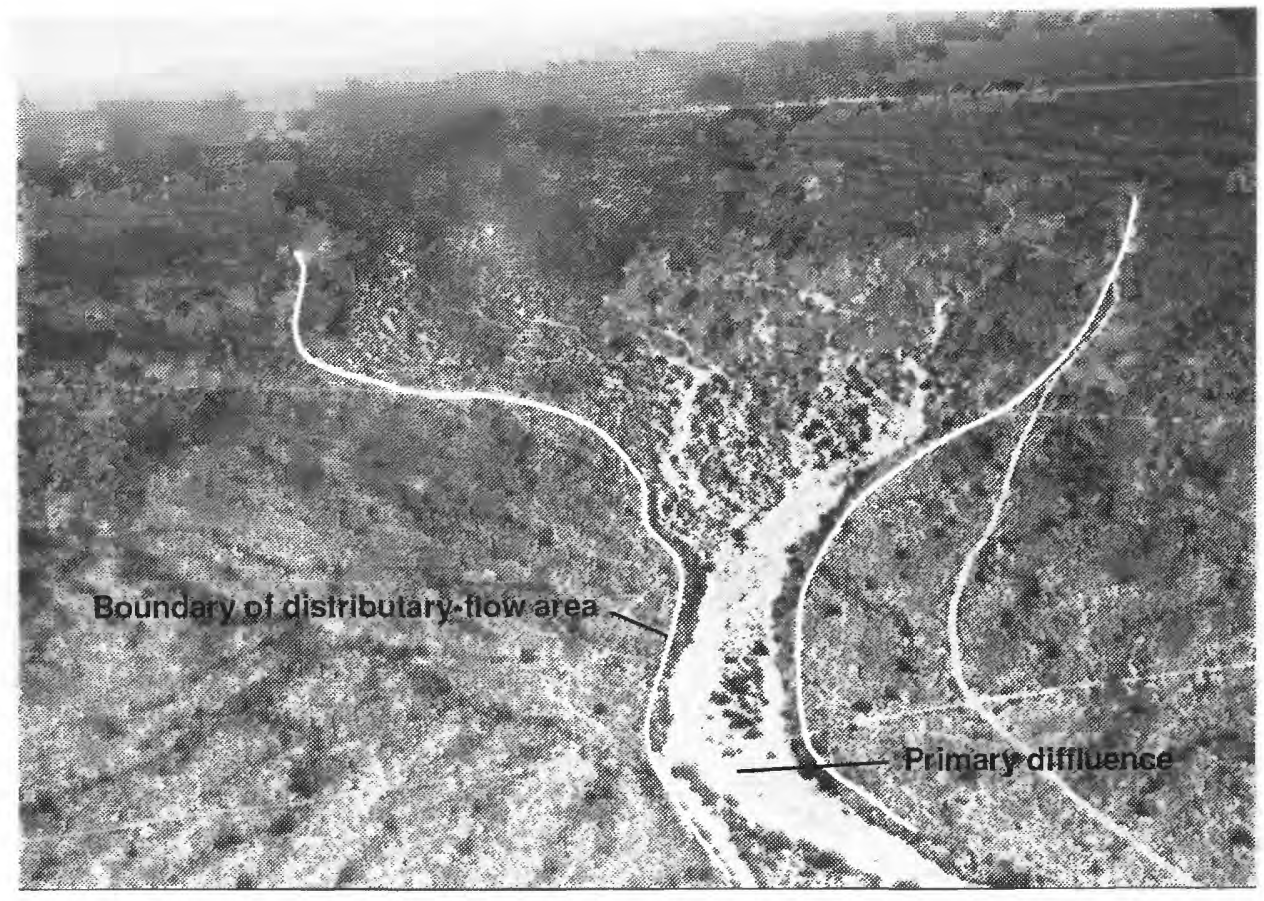

Figure 14. Looking downstream and southwest at the primary diffluence and distributaryflow area at site 36 . The bushes and trees in the middle part of the distributary-flow area are larger than those outside the distributary-flow area. The soils are light colored, and most of the area has the appearance of being inundated during a single large flood. 


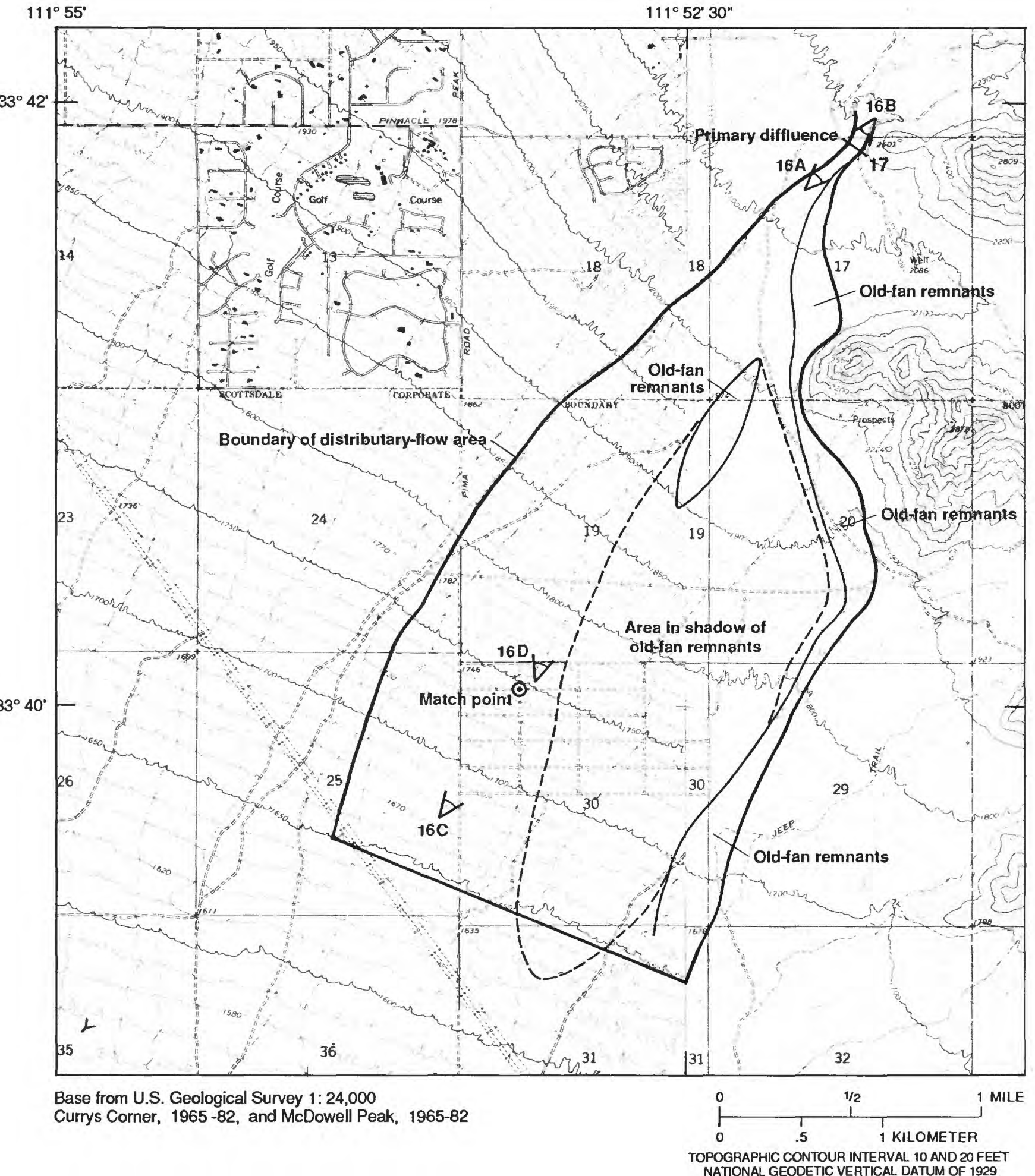

\section{EXPLANATION}

17 LINE OF CROSS SECTION-Number, 17, is number of figure where cross section is shown $16 A$ DIRECTION OF VIEW OF PHOTOGRAPH-Number, 16A, is number of figure where
photograph is shown

- MATCH POINT-Corresponds to match point on figure $16 \mathrm{C}$

Figure 15. Topography, distributary channels, primary diffluence, larger ridge areas that are above the potential level of the 100-year flood, location and view angle of photographs, and location of cross section for site 6 . 

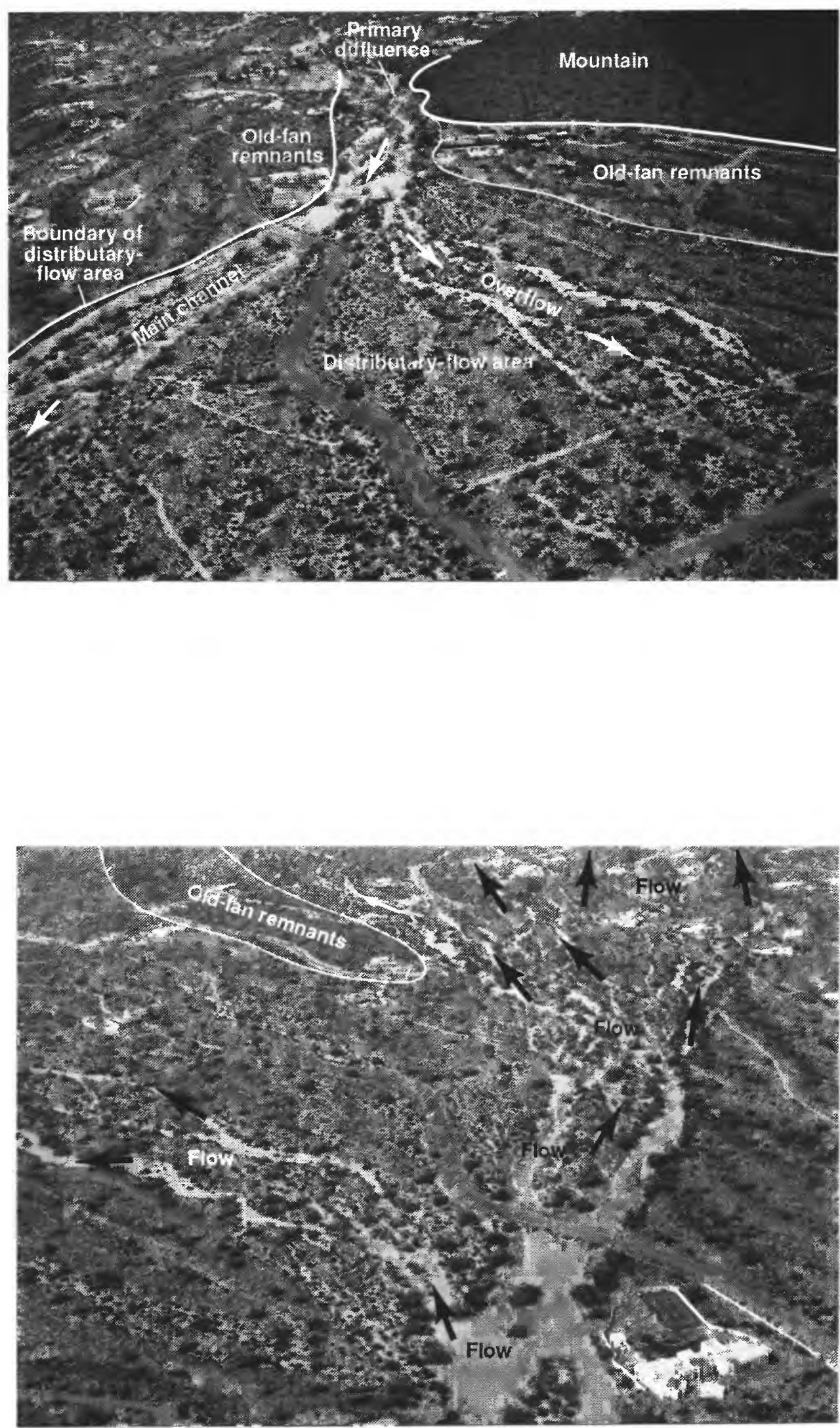

$A$, Looking upstream and northeast at the upper part of the distributary-flow area of site 6. The primary diffluence is confined by the mountain on the left-bank side and the old-fan remnant on the right-bank side.
$B$, Looking downstream and west from above the primary diffluence at the upper distributary-flow area. Most of the floodflow probably will be in the large channel to the right adjacent to the old-fan remnants. As indicated by the light-colored deposited material in the many channels, floodflow can inundate much of the area except for a few ridges. The larger trees are along the more obvious-appearing channels, but there also are scattered trees over much of the other areas that indicate the presence of distributary channels.

Figure 16. Site 6, primary diffluence, and distributary-flow area. 
$C$, Looking upstream at the middle of the distributary-flow area. The primary diffluence is in the background at the toe of the mountain. Many distributary channels are apparent where the soil color is lighter than the soil of the "shadow" area to the right of the scene. Most of the channels that drain the darker area to the right are tributary. The darker-colored soils of the few interfluvial areas in the distributary-flow area indicate these areas are above the level of the 100-year flood. Match point corresponds to match point on figure 15 .
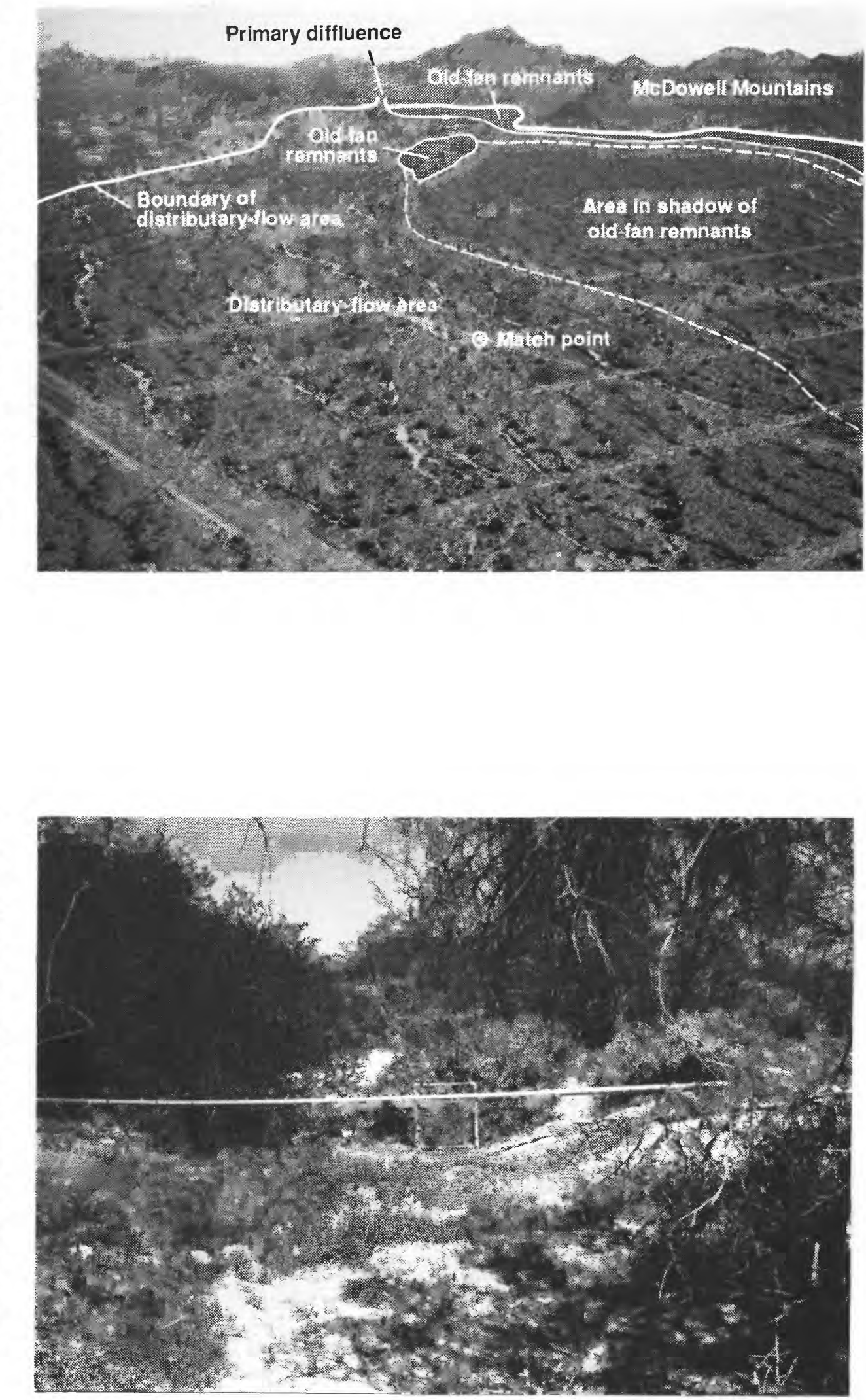

$D$, Looking upstream at distributary channel. This channel is typical of the many channels across the distributaryflow area at this elevation. The bankfull capacity is about 60 cubic feet per second or only about 1 percent of the 100-year flood. The combined capacity of the channels west of the "shadow" area at this elevation across the distributary-flow area is about 10 to 20 percent of the potential discharge of the 100-year flood. The frame of the square grid is 1.5-foot outside dimension with an internal square of 1 foot on a side and grid spacing of 1 inch.

Figure 16. Continued. 
because of the vegetation-lined, erosion-resistant banks (fig. 16D). The separated flow along and near the toe of the McDowell Mountains generally is confined, and flow depths and velocities are large. In the "shadow" area, most of the ridges are above the 100-year flood and most of the channels are stable. The "shadow" area has flood-hazard degree of about 5. A flood-hazard degree of 9 was used for the entire DFA.

The different flood characteristics of the DFA for site 6 exemplify the imprecision and difficulty of estimating the potential flood hazards and the flood-hazard degree of DFA's. The flood-hazard degree is not homogeneous, and for site 6 , different hazards are defined for large areas in the DFA. Because little of the distributary flow is in the separated channel, all of the flow might be assumed to pass to the west of the old-fan deposits with a corresponding DFA about one-half of the area shown (fig. 15). Thus, the different flood-hazard characteristics of site 6 show that an overall flood-hazard degree of 9 does not necessarily imply a homogeneous flood hazard for the DFA.

Floodflow at the PD is constricted by a high ridge of old-fan deposits on the right bank and by a mountain on the left bank. The channel geometry has been changed for construction of a road on the left side and for protection of the land on the right side. The amount of change does not appear to be large, and the surveyed cross section of the channels at the PD approximately represents the natural channel (fig. 17). The level of the 100 -year flood is about $6 \mathrm{ft}$ below the top of the left bank.

The DFA appears to be inset in old-fan deposits (an inset fan) and is bounded on the right by old-fan remnants. On the left, the DFA is bounded mostly by mountains and in places by old-fan remnants. Soils of the active DFA (flood-hazard degree of 9 or 10) are lighter than the soils of the adjacent old-fan remnants and of the "shadow" area, and desert varnish is not present. Desert varnish, however, is seldom found on granite fragments that weather easily in the desert environment of Arizona.

The slope of the DFA flattens downstream from the PD and then steepens for about $4,000 \mathrm{ft}$ (fig. 18). Near the island of old-fan remnants, the slope of the DFA progressively flattens to the toe where the channels become tributary. About $8,000 \mathrm{ft}$ downstream from the toe, the slope generally is constant.

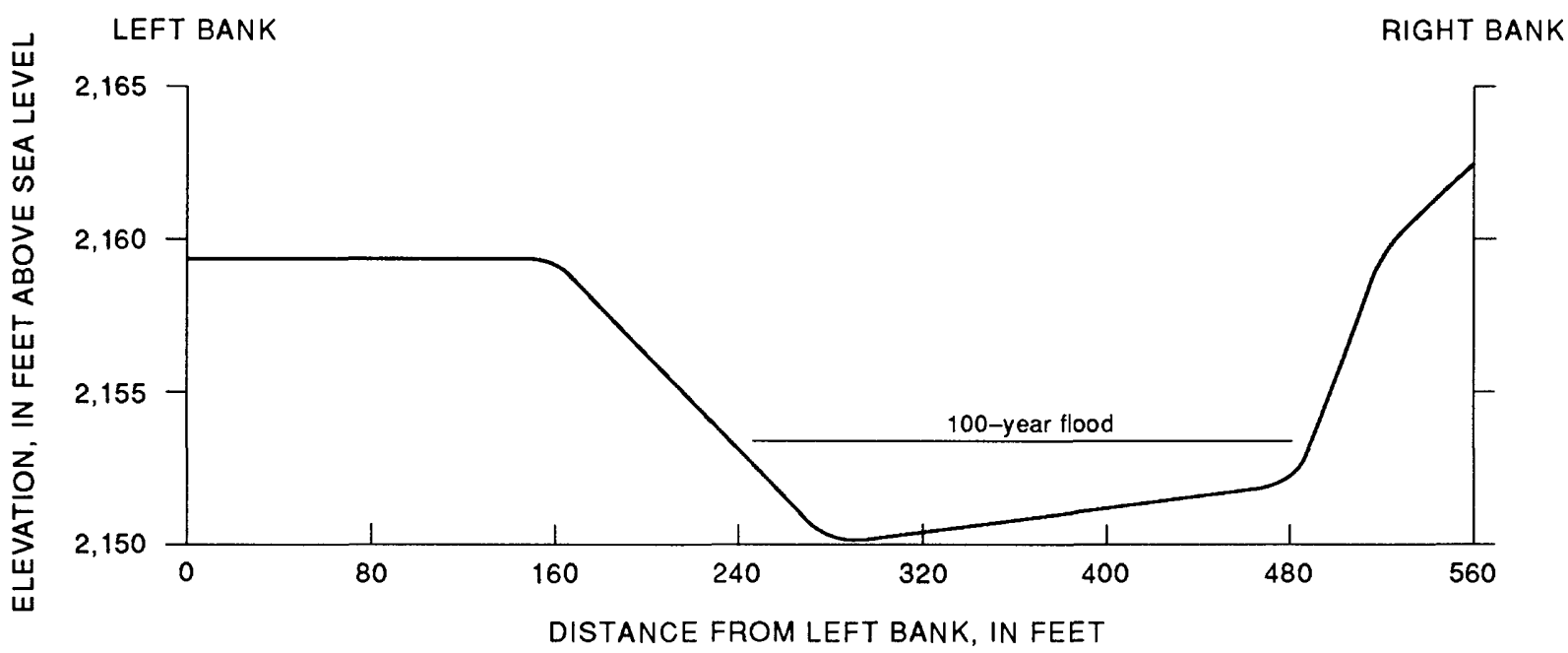

Figure 17. Cross section of primary diffluence and upper distributary-flow area showing approximate level of the 100-year flood for site 6. 

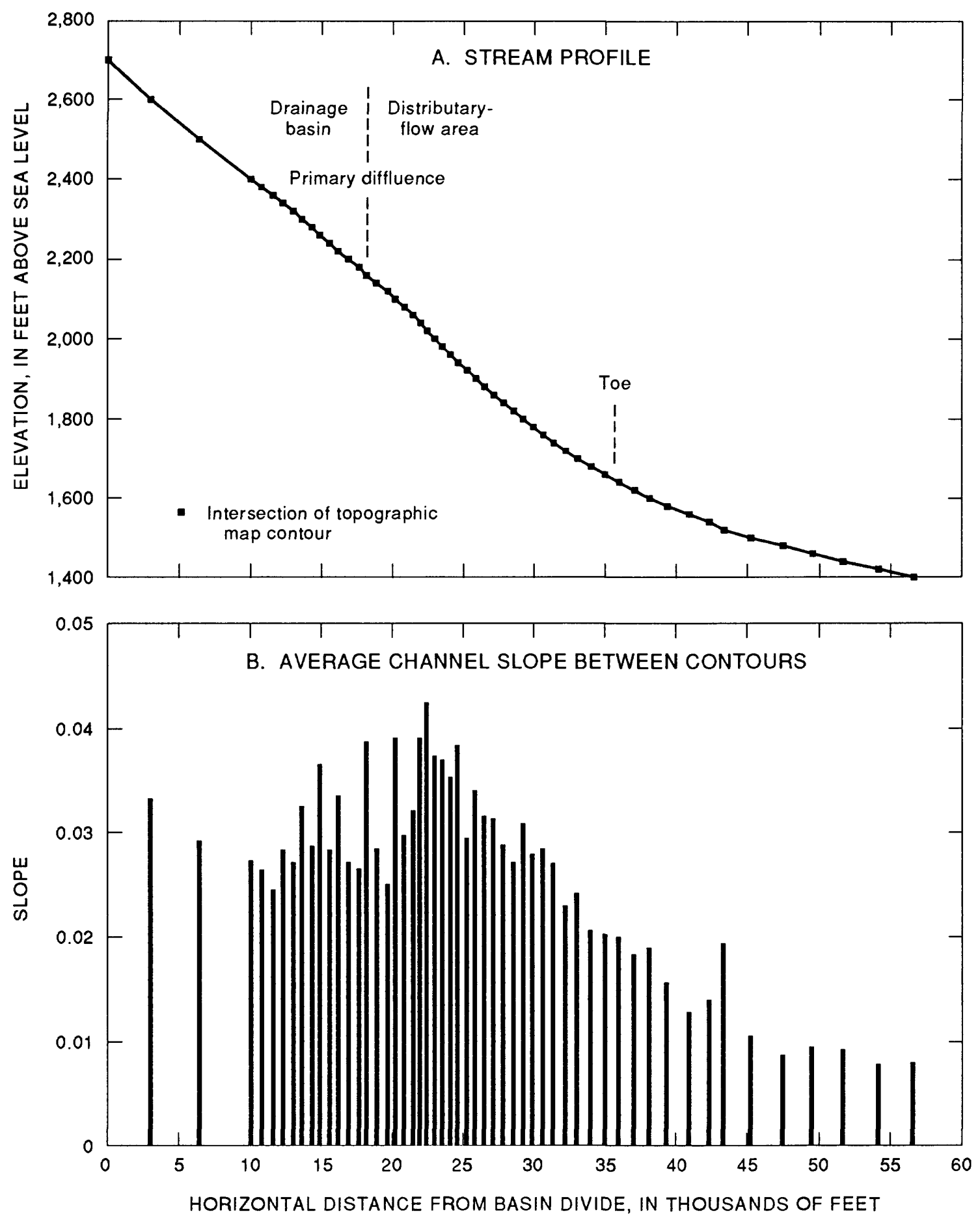

Figure 18. Stream profile and average slope of channel between topographic-map contours showing location of primary diffluence for site and toe of distributary-flow area for site 6. 


\section{Site 23}

Site 23 is at the southern end of the McDowell Mountains in eastern Maricopa County. The flood-hazard degree over the entire DFA of site 23 is 10 . Few ridges are present, and the transverse slope of the interfluvial areas between the channels is small in relation to the general land slope, which is about 2.7 percent. The small transverse slope in the upper DFA is evidenced by the absence of crenulations on the 1,600-foot contour across the DFA (fig. 19). The Granite Reef Aqueduct of the Central Arizona Project (CAP) crosses the DFA (fig. 20A) and effectively dams floodflow that emanates from the PD. The characteristics of this DFA are for conditions before construction of the aqueduct. The aqueduct, therefore, is not shown in figure 19. At the PD, the channel capacity is about three times the peak discharge of the 100-year flood (fig. 20B and 21A). Downstream from the PD, the channel gradually widens (figs. 20A and C). About 2,000 $\mathrm{ft}$ downstream from the $\mathrm{PD}$, many angular boulders are present, and little relief occurs across the DFA (figs. 20D and E). Much of the recent floodflow appears to be on the right part of the DFA; however, little reddish oxidation is on the boulders over the entire upper DFA.

The DFA of site 23 is strewn with angular cobbles and boulders. Much of the deposited rock appears to be from old-fan deposits upstream from the PD. From the mountain front to about $2,000 \mathrm{ft}$ downstream at the PD, the channel is deeply entrenched in old-fan deposits.

The soils of the entire DFA are lighter than the surrounding soils of the old-fan remnants. Some desert varnish is present on rocks adjacent to the DFA; however, no varnished rocks were observed in the DFA. More large trees are in the DFA than on surrounding old-fan surfaces. Also, as commonly found on other DFA's with high flood-hazard degrees, few, if any, saguaro cacti are present in the DFA. Only one small saguaro was observed in the DFA; however, several saguaros are in the area adjacent to the DFA.

The slope of the stream channel is distinctly less than the slope upstream from the PD for several hundred feet downstream from the PD (fig. 22). Channel slope increases gradually from just downstream from the $P D$ to about $0.5 \mathrm{mi}$ downstream. Floodwater of the 100-year flood will overtop the left bank about $700 \mathrm{ft}$ downstream from the PD (fig. 20C). About $1,100 \mathrm{ft}$ downstream from the PD, the 100-year flood will overtop the right bank of the main channel (fig. 21B). The 2- and 10-year floods are confined within the banks of the main channels to about $1,500 \mathrm{ft}$ downstream from the PD where the banks are low and several small channels are present (fig. 21C). At $1,800 \mathrm{ft}$ downstream from the $\mathrm{PD}$, the capacity of the main channel is greater than the 10-year flood (fig. 21D), but significant amounts of floodflow will overtop the low banks upstream and enter adjacent distributary channels. Near the top of the subtle hump in the profile of the DFA (fig. 22) at about $2,800 \mathrm{ft}$ downstream from the PD, several distributary channels are separated by ridges that are about $3 \mathrm{ft}$ high (fig. 23).

\section{GEOMORPHIC CONSIDERATIONS}

Alluvial fans are complex landforms that commonly are formed by deposited debris when floodwater leaves the confines of mountain canyons and narrow channels. Alluvial fans are in various stages of development. Actively aggrading fans tend to be geologically young; flow paths reportedly move over wide areas depositing debris and spreading floodwater (site 23 for example). As fans aggrade, they become large relative to the drainage basin upstream. The magnitude of floodwater and debris discharge is less per unit area of the alluvial fan, and large areas become isolated from debris deposition and floodflow. Some alluvial slopes have networks of incised distributary channels that are tens to hundreds of thousands of years old that tend to be stable or slightly eroding. Distributary channels on such surfaces are incised into the landform (site 2 for example). The paths of flow on old fans are stable; flow paths of young aggrading fans are unpredictable and can change during flooding.

Young fans can result from tectonic uplift of a mountain relative to the adjacent basin. Over a given period of time the loci of fan deposition will be at a mountain front if the uplift equals or exceeds the sum of the channel downcutting in the mountain and the amount of fan deposition (Bull, 1977). Bull also demonstrates that fans develop incised channels where the rate of mountain-channel 


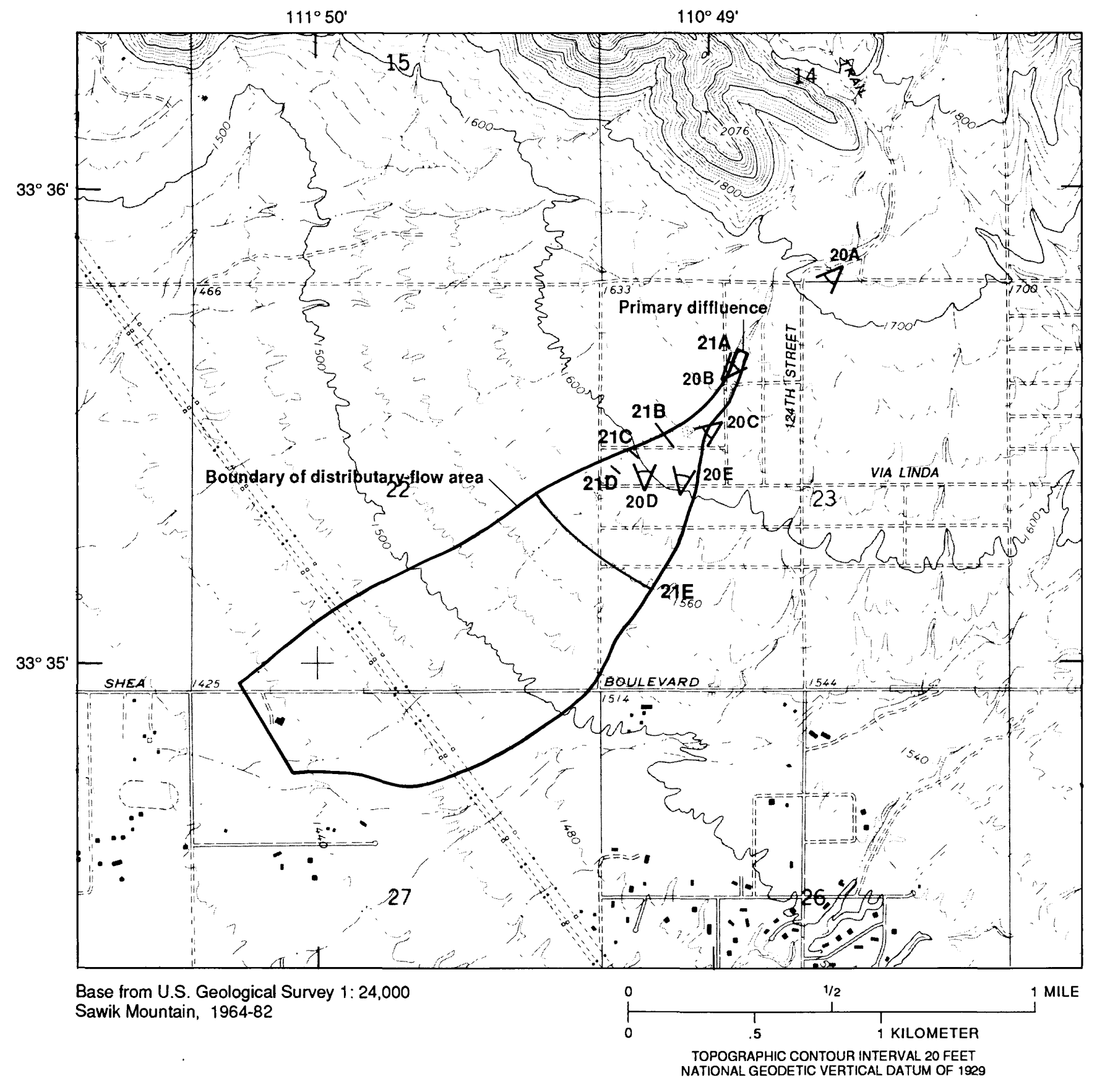

\section{EXPLANATION}

21A - LINE OF CROSS SECTION-Number, 21A, is number of figure where cross section is shown

$20 A$ DIRECTION OF VIEW OF PHOTOGRAPH-Number, 20A, is number of figure where
photograph is shown

Figure 19. Topography, distributary channels, primary diffluence, larger ridge areas that are above the potential level of the 100-year flood, location and view angle of photographs, and location of cross sections for site 23. 

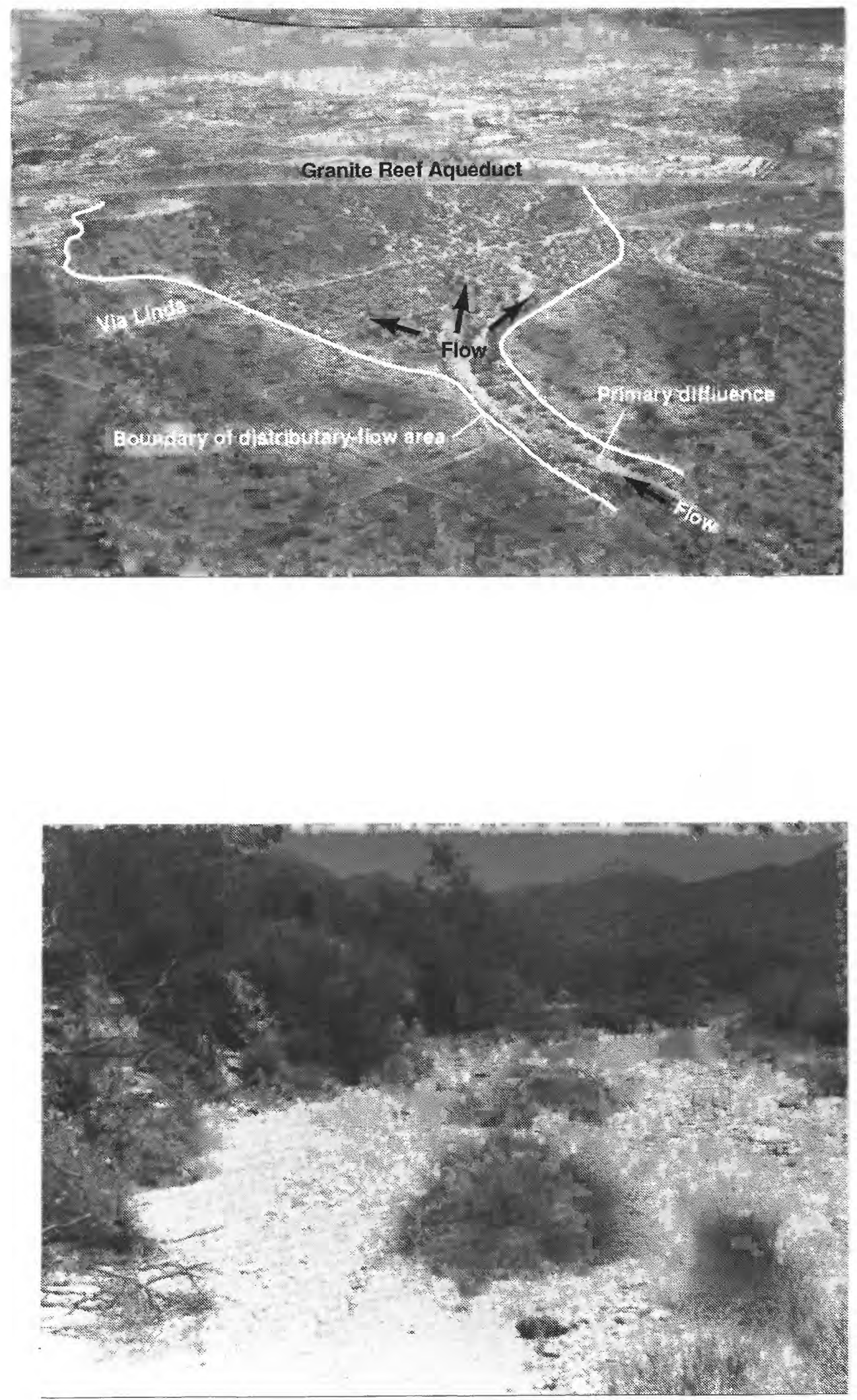

A, Looking downstream and southwest at primary diffluence at distributary-flow area of site 23. The number and rather heterogeneous distribution of the larger trees on the distributary-flow area are markedly different from those of the trees on adjacent land. Trees on adjacent old-fan remnants are mostly along tributary channels. The lighter colored soils on the right side of the distributary-flow area indicate recent deposition and the probable location of recent floodflow. The absence of high interfluves, the presence of large deposits of angular boulders, and the presence of old trees indicate that floodflow is likely over the entire distributary-flow area.

$B$, Looking upstream at the main channel and right bank of the primary diffluence. The bank is cemented conglomerate consisting of many boulders. Several cobbles and boulders at the top of the bank are coated with a dark desert varnish, and the bottoms of stones are covered with a highly oxidized material. The frame of the square grid is 1.5-foot outside dimension on a side.

Figure 20. Site 23, primary diffluence, and distributary-flow area. 
C, Looking downstream at the upper distributary-flow area where floodflow is unconfined. Many of the large boulders are from the old-fan deposits in which the present channel is incised for about 0.4 mile upstream.
D, Looking upstream and northwest at deposited boulders on the left-bank side of the distributary-flow area where recent flooding is not apparent. The saguaro cactus in the background appears to be a few hundred years old and is on adjacent land. The frame of the square grid is 1.5-foot outside dimension on a side.
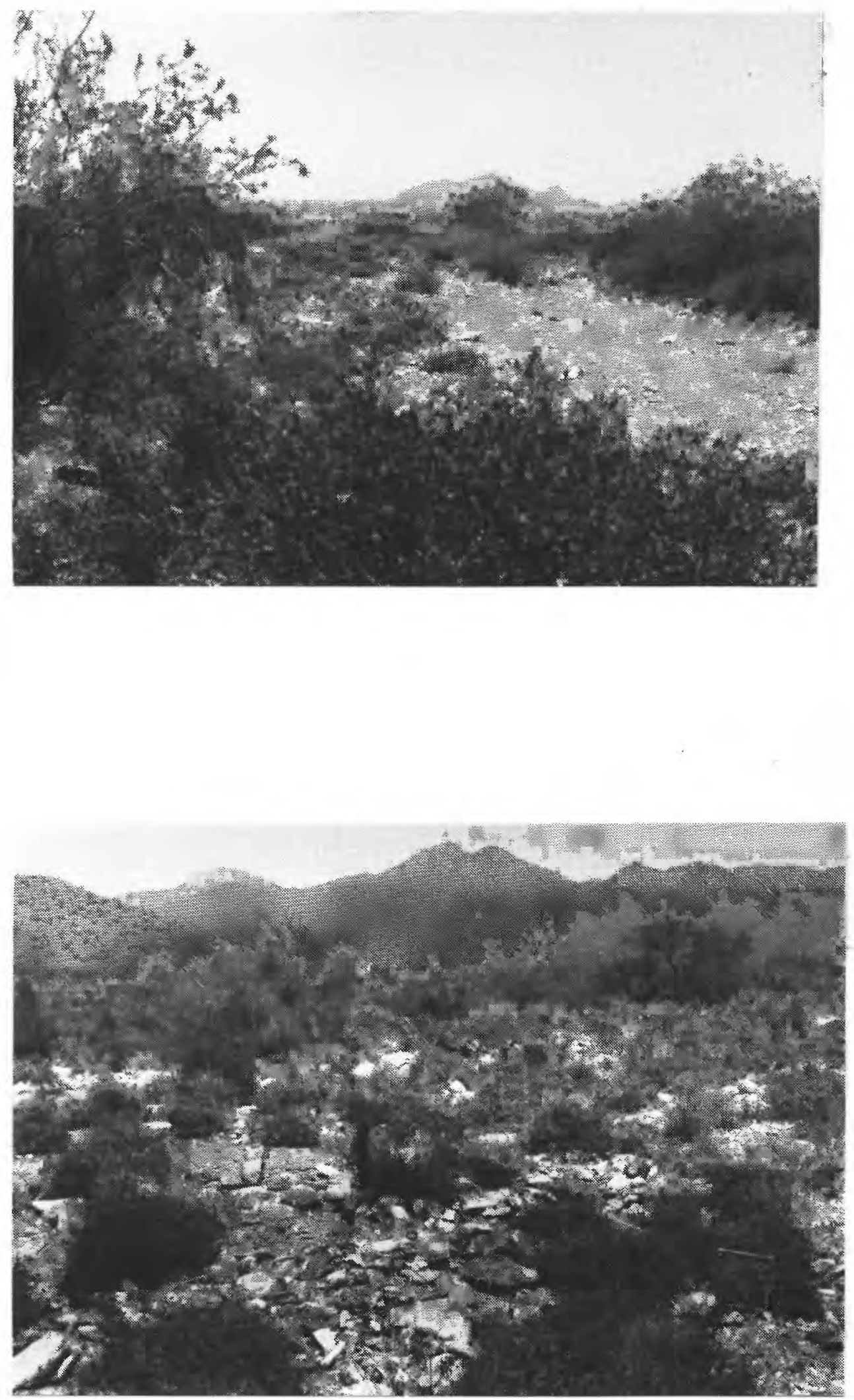

Figure 20. Continued. 


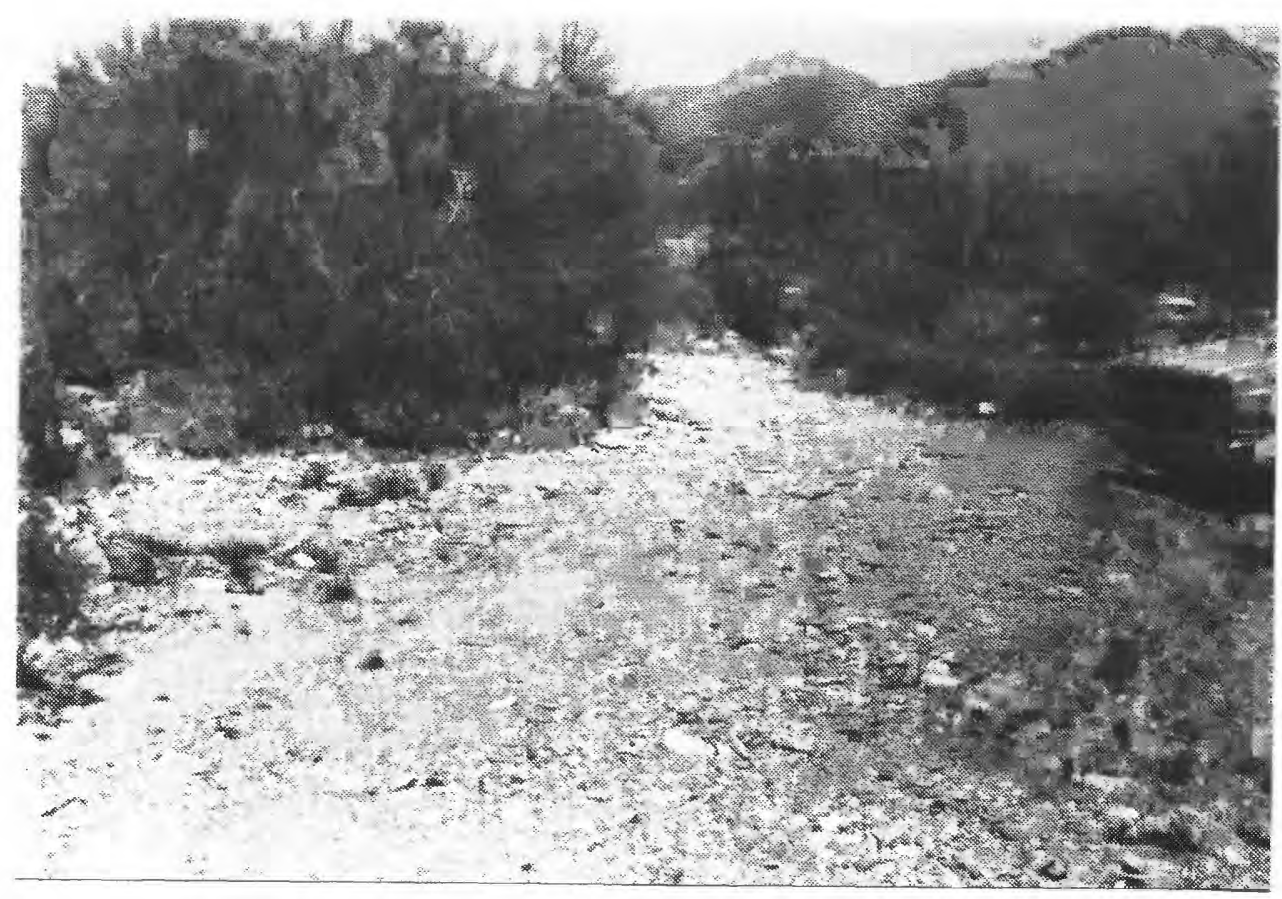

$E$, Looking upstream and northeast at the largest defined distributary channel on the right side of the distributary-flow area. The small ridge on the right behind the truck is about 3 feet high and is the left side of the bed. A ridge to the left of the scene is only about 1 foot high and is difficult to distinguish when viewed on the ground. Most of the deposited material in the middle and upper distributary-flow area is larger than the rocks in the photograph. The frame of the square grid is 1.5 -foot outside dimension on a side.

Figure 20. Continued. 
A

LEFT BANK

RIGHT BANK

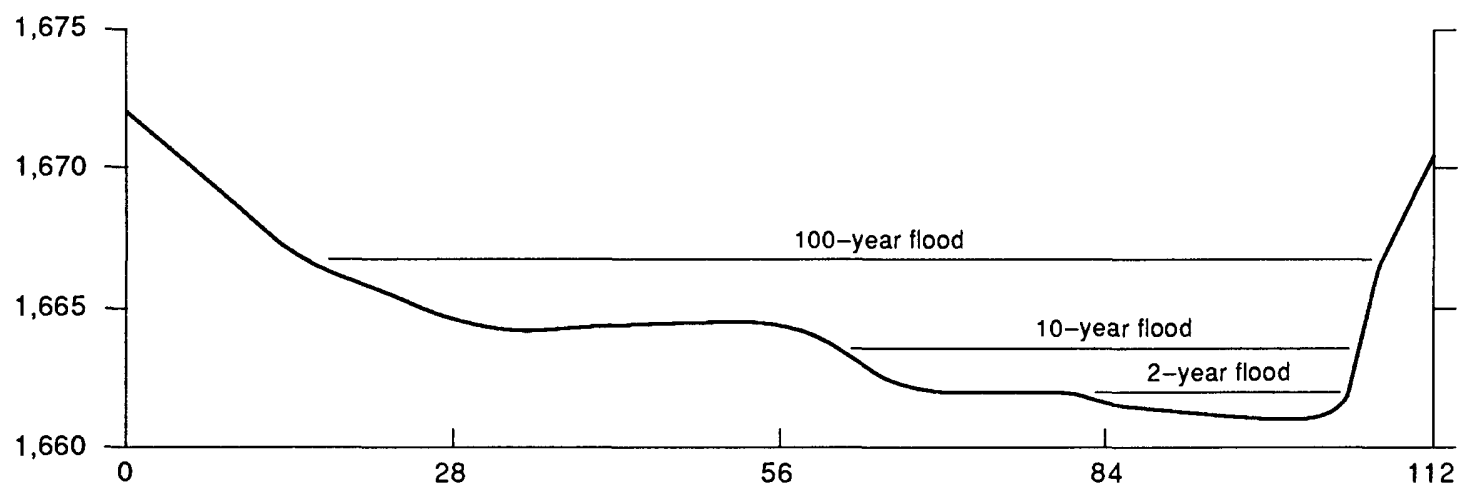

B
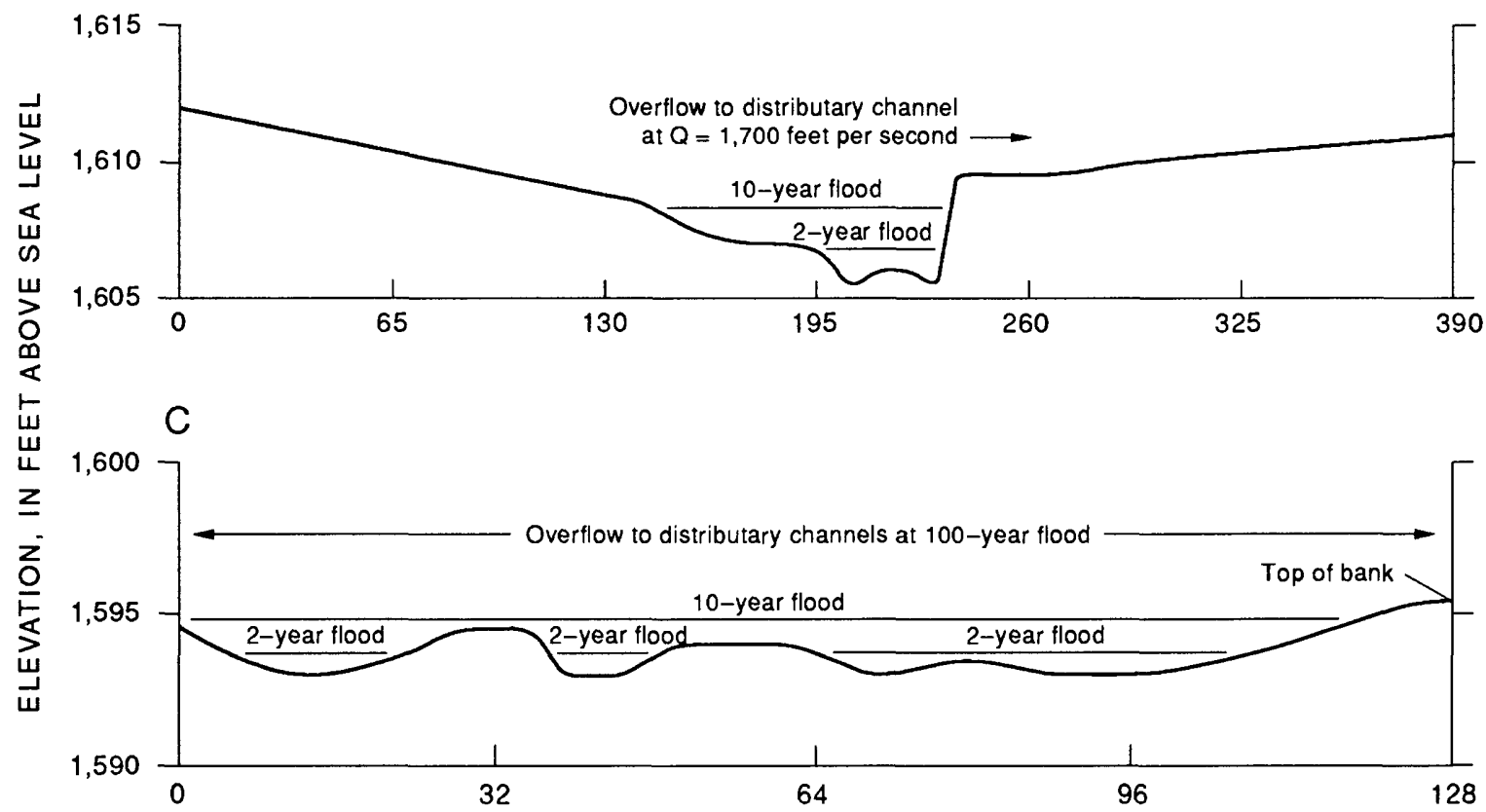

D

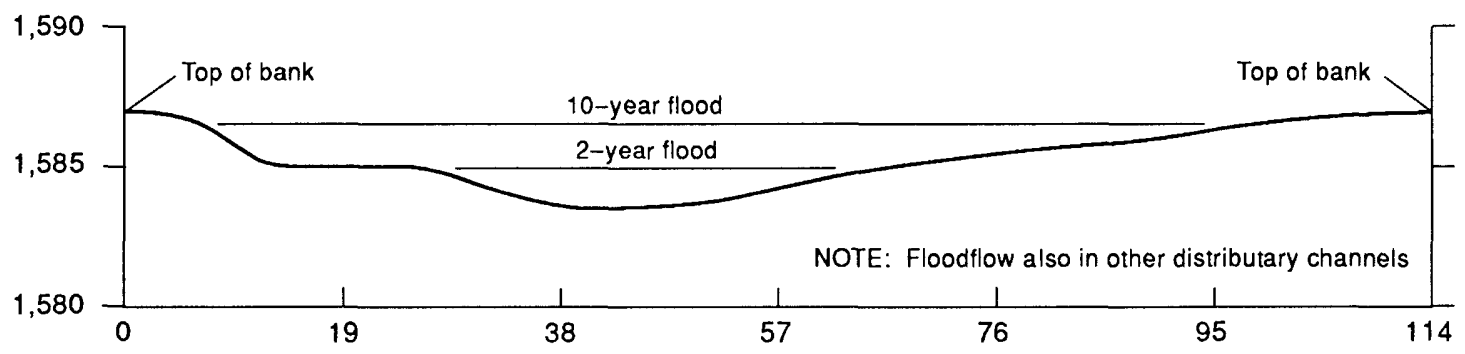

DISTANCE FROM LEFT BANK, IN FEET

Figure 21. Cross sections of primary diffluence and along the main channel in the upper distributary-flow area showing approximate level of the 2-, 10-, and 100-year floods for site 23. A, Primary diffluence. $B, 1,100$ feet below primary diffluence. $C, 1,500$ feet below primary diffluence. $D, 1,800$ feet below primary diffluence. 

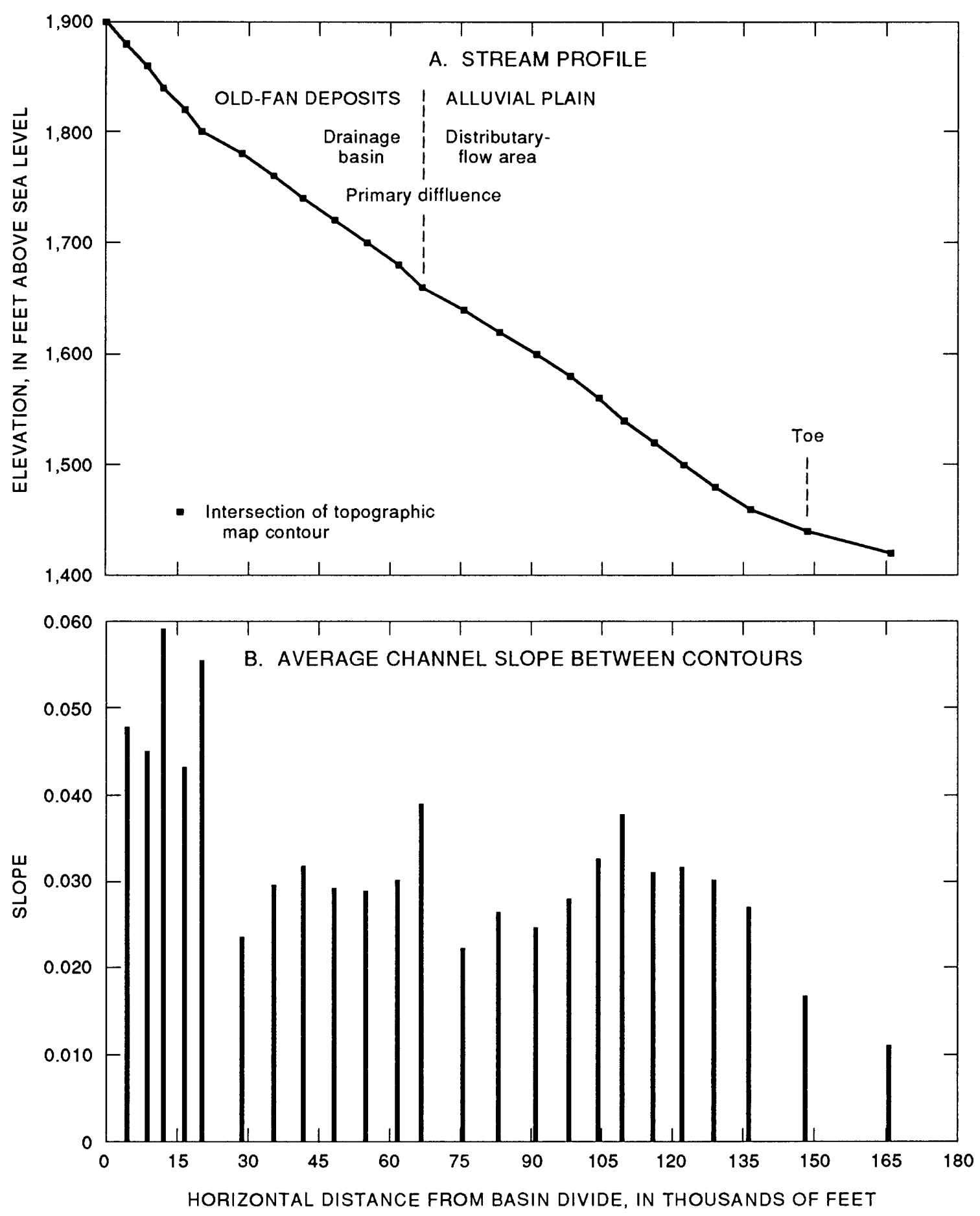

Figure 22. Stream profile and average slope of channel between topographic-map contours showing location of primary diffluence for site and toe of distributary-flow area for site 23. 
downcutting is (1) greater than or equal to the rate of mountain uplift and (2) is greater than or equal to the erosion of the alluvial-fan deposits adjacent to the mountains. For regions like southern and central Arizona where limited tectonic activity and mountain uplift occurs, the loci of deposition of most DFA's has shifted permanently downslope from the mountain fronts. According to Bull (1977, p. 252) the fanhead trench can be:

"...removed as a possible area of deposition and the degree of soil-profile development will provide clues as to the length of time since the fanhead area last received deposits. The complete and intense weathering profiles that are characteristic of the fanhead areas of many entrenched alluvial fans also indicate that the rate of erosion of the abandoned depositional surface has been less than the mean rate of soil-profile development."

The channels of a stable DFA (a DFA with a stable or degrading surface and incised distributary channels) commonly are entrenched. The distributary channels are within the surface of the landform (fig. 24A). Floodwater that overtops the channel banks generally spreads over adjacent land between stable interfluves separating the distributary channels. The banks of the channels are lined with large desert trees, such as palo verde, and the interfluves are covered with bushes, scattered trees, and saguaro cacti. The channels of unstable DFA's (young aggrading alluvial fans) commonly are perched in relation to the ground at equal distances from the apex or PD (fig. 24B). Floodwater can overtop or breach the perched banks and spread over the adjacent low-lying land (site 23, fig. 21C). The active water courses can fill with debris and change location (avulse) suddenly during flooding. Vegetation generally is limited on the most unstable alluvial fans in the southwestern United States. In central and southern Arizona, few if any, saguaro cacti are on DFA's with flood-hazard degrees of 10 ; however, scattered bushes and trees are on such DFA's. On many alluvial fans, a distinct change in the type, size, and density of vegetation occurs at the fan boundaries.

This brief description of the aging and formation of alluvial fans (one kind of DFA) is an oversimplification of a complex geologic process. The effects of factors, such as climate changes, structural warping and unwarping of uplands, downwarping of lowlands (Cooley, 1977), and changes in the base level of streams draining intermontane valleys, have been ignored. The complex formation of alluvial fans by deposition of sediment from both floodflows and debris flows also is beyond the scope of this report. Of importance is the fact that the flow paths of DFA's are stable and unstable in engineering time, and some surfaces of DFA's are aggrading as others are degrading.

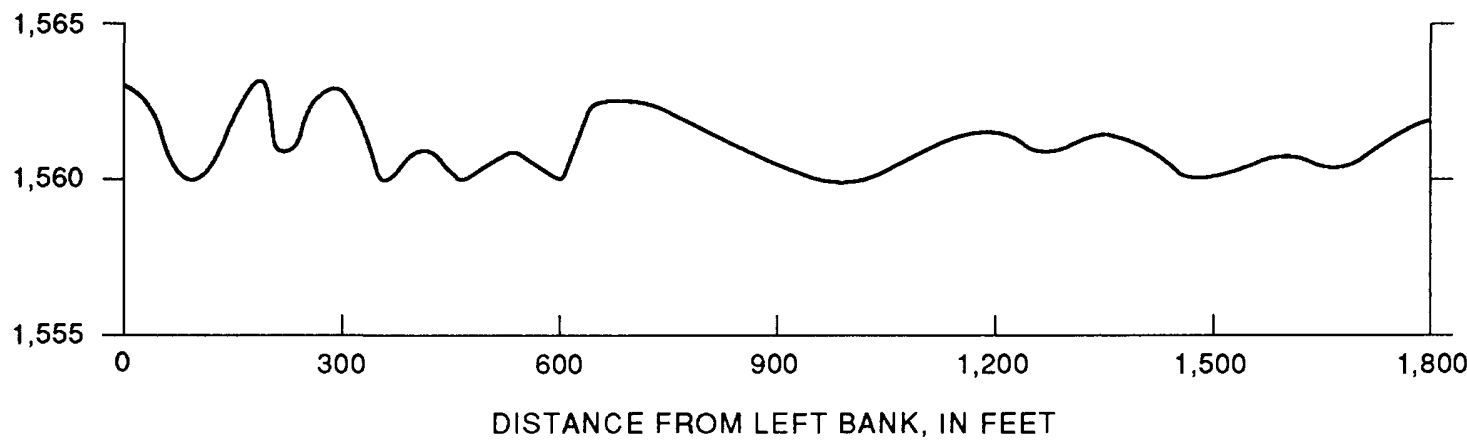

Figure 23. Cross section of upper distributary-flow area about 2,800 feet downstream from the primary diffluence at the 1,560-foot elevation contour of site 23 . 


\section{A. STABLE FLOW PATHS}

LEFT BANK

RIGHT BANK

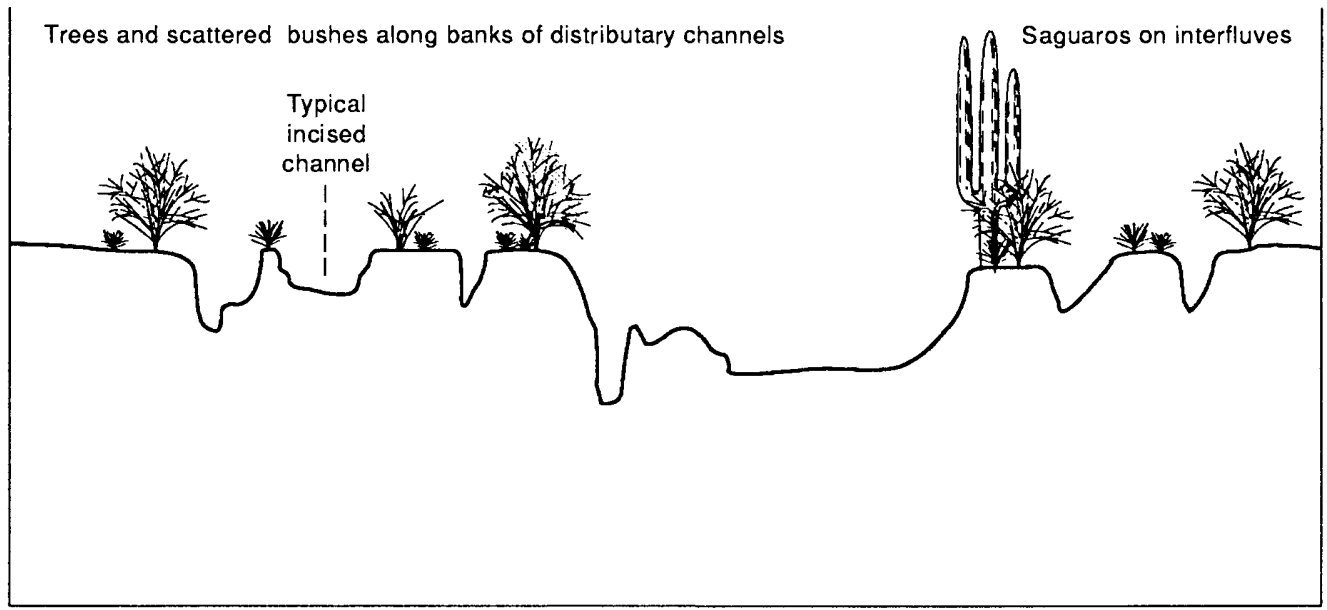

Not to scale

B. UNSTABLE FLOW PATHS

\section{LEFT BANK}

RIGHT BANK

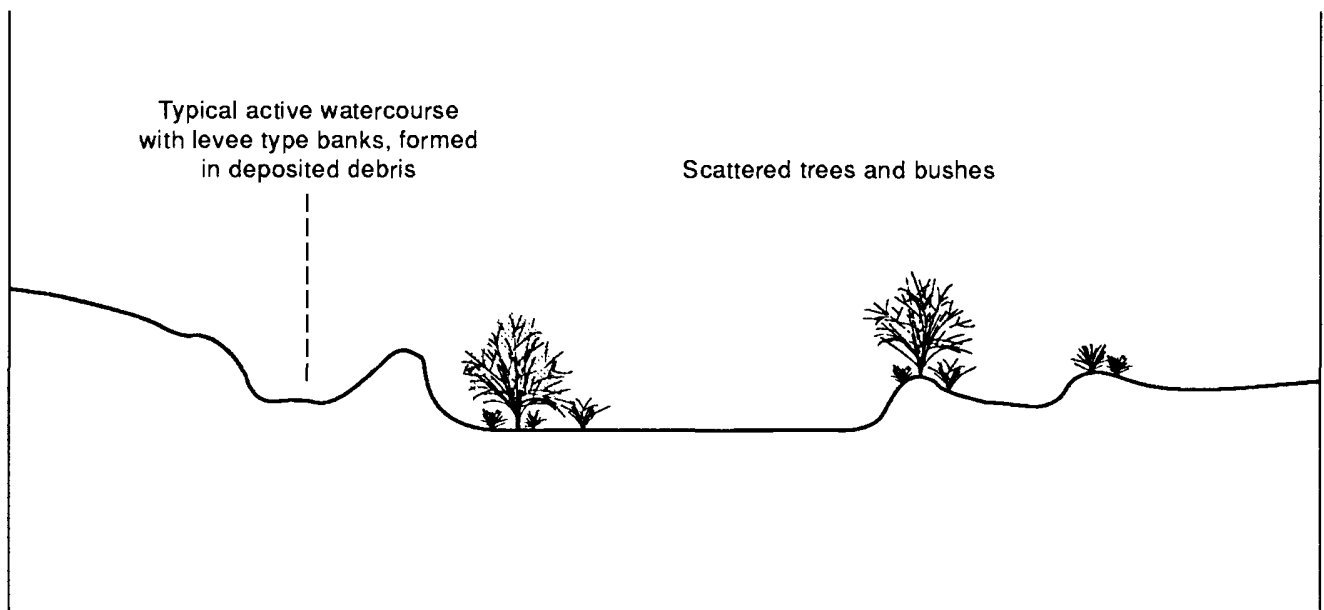

Not to scale

Figure 24. Schematic cross sections at equal distances from the primary diffluence. $A$, Stable flow paths. $B$, Unstable flow paths. 


\section{SOIL CHARACTERISTICS}

Soil characteristics commonly found in soil surveys (Camp, 1986) are useful for assessing the stability of the channels and surface of DFA's (Bull, 1977, p. 252). The soils of stable surfaces, such as those for some of the area of sites $2,6,30$, and 39 , are well developed with dark reddish-brown oxidation a few inches below the surface and lime masses and cemented Pleistocene sediments near the surface. Soils of potentially unstable surfaces, such as those for the DFA of site 23, parts of the DFA of sites 6 and 39, and along the entrenched distributary channels of site 2 , are lighter with more yellow and tan and are not well developed near the surface. Soils of aggrading alluvial fans with unstable paths of flow can have developed soil horizons with weak cementation in the B horizon at depth. Soils of stable or eroding DFA's with entrenched channels have developed soil near the surface commonly with channel incision into the cemented B horizon.

Sedimentary deposits along the distributary channels and flood plains within the stable Pleistocene alluvium show little soil development and retain their original sedimentary layering that shows them to be streamflow rather than debris-flow deposits. The individual beds within the deposits commonly are thin and loose except for occasional thin cemented plates. The sediment tends to be deposited on the inside of meander bends. The weak soils that form on the deposits are mapped as Antho and Carrizo soils (Camp, 1986). Soils like the Antho are layered with sorted material deposited by different floods or at different times during a flood. These Holocene soils are along the distributary channels and flood plains of sites $2,6,30$, and 39 and in places along the channels of site 23 .

Degrading areas with developed soils on Pleistocene sediments that are traversed by incised distributary channels may be considered stable because the channel location and geometry do not change over periods of many years. For example, on the basis of a comparison of aerial photographs taken in 1953 and 1991, the location of the channels of site 2 did not appear to change for a period of 38 years, which included at least one major flood on June 22, 1972. The channels have downcut and, in places, are restricted by cemented sediments that form the local grade. The flow paths of these surfaces in Maricopa County, which are entrenched into the cemented sediments of the B horizon of developed soils and separated by stable ridges with developed soils, are considered stable.

Unstable flow paths and surfaces with soils that are subject to flooding are commonly found on aggrading DFA's. The color of soils on aggrading DFA's typically is more yellow and $\tan$ (7.5YR to 10YR on the Munsel Color Chart) than the redder Pleistocene soils of eroding DFA's (2YR to 5YR). The soils of aggrading DFA's generally lack the lime masses and concretions near the surface that are found in the Pleistocene soils of degrading DFA's. Any lime present in aggrading DFA's generally is disseminated, but the soil may still effervesce slightly. Lastly, the texture of soils on aggrading DFA's generally is loam and loamy sand to sandy loam and sand. On aggrading DFA's these soils generally lack silty clay loam near the land surface that is related to the weathering process (C.C. Cochran, soils specialist, U.S. Soil Conservation Service, written commun., 1989). The DFA of site 23, for example, is mostly composed of unstructured Antho and Carrizo soils (Camp, 1986) that are only weakly cemented and subject to channeling, deposition, and streambank erosion.

\section{CHANNEL STABILITY AND SEDIMENT YIELD}

Distributary-flow areas (DFA's) in Maricopa County and southwestern Arizona generally are dissected to a greater extent than those described in California and Nevada (DNA Consulting Engineers, 1985; Dawdy, 1979). This is probably the result of the older age of DFA's in Arizona and the limited amount of sediment leaving the mountainous drainage basins in southwestern Arizona. Because the channels of many DFA's are entrenched, floods typically are contained within incised channels and adjacent flood plains and do not spread out across the fans. The banks of the incised channels typically are erosion-resistant cemented conglomerate.

Sediment in the channel system is derived from weathering in the mountainous areas of the drainage basins. Most mountainous areas above 
the DFA's are bare rock, and soils are thin. The stream channels in the mountains generally have little fine-grained material, indicating that available transportable weathered rock is removed from most of the basin areas above the PD's by runoff.

\section{Runoff and Sediment Transport}

Runoff from storms commonly is infrequent, of short duration, and not in sufficient amounts to transport much sediment. Annual precipitation for most of Maricopa County is less than $8 \mathrm{in}$. except in the higher mountains and in the eastern and northern areas where about 12 in. is typical. Thunderstorms produce most of the runoff, and runoff typically occurs for only a few hours each year. In the central and western basins of Maricopa County, no runoff occurs in higher-order streams at the mountain fronts in about one-third of the years. The variation of annual storm discharge is large (Hjalmarson, 1991), and long periods of little or no runoff and short infrequent periods of intense runoff are typical. Less than 1 percent of the annual precipitation probably reaches the higher-order streams as runoff at the mountain fronts. Runoff of most floods is not of sufficient duration and magnitude to move sediment past the PD and through the DFA. Typical floods that originate above the PD or within the DFA are short lived, and floodwater is completely lost to infiltration into the sandy channel beds. The complete loss of floodwater to infiltration and evaporation within a few hours is common in central and southern Arizona (Hjalmarson, 1984). Sediment is moved during these short periods of floodflow and deposited downstream until it is again remobilized by another infrequent floodflow perhaps a year or two later. Sediment passes into and through the DFA's in pulses and seldom is there enough runoff to transport much sediment through the DFA during a single storm.

\section{Channel-Bed Material}

Samples of the channel bed were taken at 12 of the sites during field reconnaissance. Grain-size distribution of these samples was determined by dry-sieve analysis (table 3). Samples of the noncohesive sediment forming the channel bed were collected in the upper few inches of the bed at the primary diffluence.

Estimates of particle size also were made using a 1-foot-square grid subdivided by string that outlined 1-inch squares. The grid was placed on the channel beds and photographed (fig. 3E). Amount and size of the larger grain sizes was estimated using the two-dimensional grid. The median diameter size at site 3 was estimated by a visual comparison of the photographs of the grid on the channel beds at sites $1-3$. The median diameter at site 3 appeared to be about the average of the median diameter at sites 1 and 2 .

\section{Channel Competence}

Estimates of the channel competence to transport the bed material were made at the primary diffluence of the study sites. Competence was represented by the maximum grain size that could be moved at the peak discharge of the 2-, 10-, and 100-year floods; this "competent size" was compared to several representative grain sizes of the bed material.

Channel competence was determined at surveyed cross sections using the Du Boys equation for bed shear stress:

$$
\tau=Y R S,
$$

where

$$
\begin{aligned}
& \tau=\text { shear stress on the bed, in pounds per } \\
& \Upsilon=\text { specific weight of water, in pounds per } \\
& R=\text { hydraulic radius, in feet; and } \\
& S=\text { slope of channel bed. }
\end{aligned}
$$

The diameter of the largest moving grain was determined from the modified Shields relation (Vanoni, 1975, p. 193):

$$
d c=\tau /\left[0.047\left(Y_{g}-Y\right)\right],
$$

where

$$
d c=\text { diameter of the largest moving grain }
$$


$\Upsilon_{g}=$ specific weight of the bed sediment, in pounds per cubic foot.

Floodflows appear to be competent to move most of the bed material of the defined channels that emanate from the PD of the sample of sites. The channel competence of the 2-year flood was several times more than the grain size of the bed material at the PD (table 3). At several sites, the competent size that could be moved by the 10 -year flood is an order of magnitude greater than the median grain size of the sample of the channel bed. Also, the channel competence along the incised channels in the DFA's appears considerably larger than the grain size of the channel beds (Camp, 1986, table 13). The channel competence of incised channels of DFA's commonly is not much less than the competence at the PD's because the flow is confined and the channel slopes are about the same. Also, because the channels in the drainage basin above the PD's commonly are confined and steep, floodflows appear competent to move the sand-and-gravel material of the drainage basin.

\section{Sediment Yield}

The large channel competence indicates that the amount of sediment transported to the DFA's

Table 3. Peak discharge and competence at the 2-, 10-, and 100-year recurrence intervals and grain sizes of the channel bed (D50, D75, D84, and D90) at the primary diffluences for sites in and near Maricopa County, Arizona

\begin{tabular}{|c|c|c|c|c|c|c|c|c|c|c|}
\hline \multirow[t]{2}{*}{ Site } & \multicolumn{3}{|c|}{$\begin{array}{l}\text { Site discharge, at indicated } \\
\text { recurrence interval, in cublc feet } \\
\text { per socond }\end{array}$} & \multicolumn{3}{|c|}{$\begin{array}{l}\text { Channel competence, in } \\
\text { millimeters, at indicated } \\
\text { recurrence interval }\end{array}$} & \multicolumn{4}{|c|}{$\begin{array}{l}\text { Grain size, in millimeters, at Indicated } \\
\text { amount, In percent of bed materlal finer than } \\
\text { the size given }{ }^{2}\end{array}$} \\
\hline & 2 & 10 & 100 & 2 & 10 & 100 & D50 & D75 & D84 & D90 \\
\hline 1 & 97 & 805 & 4,290 & 19 & 50 & 94 & 1.82 & 4.5 & 6.30 & 8.0 \\
\hline 2 & 128 & 1,060 & 5,690 & 38 & 63 & 130 & 1.32 & 2.9 & 4.00 & 5.3 \\
\hline 3 & 78 & 639 & 3,350 & 25 & 38 & 63 & $3,41.5$ & $\left({ }^{3}\right)$ & $\left({ }^{3}\right)$ & $\left({ }^{3}\right)$ \\
\hline 6 & 152 & 1,290 & 6,850 & 44 & 130 & 300 & 2.98 & 5.8 & 7.90 & 10.0 \\
\hline 22 & 70 & 672 & 3,570 & 25 & 44 & 110 & 5.59 & 16.0 & $\left({ }^{5}\right)$ & $\left({ }^{5}\right)$ \\
\hline 23 & 79 & 685 & 3,630 & 25 & 110 & 230 & 2.33 & 5.0 & 6.80 & 8.2 \\
\hline 25 & 649 & 2,450 & 7,020 & 82 & 130 & 230 & $\left({ }^{3}\right)$ & $\left({ }^{3}\right)$ & $\left({ }^{3}\right)$ & $\left({ }^{3}\right)$ \\
\hline 26 & 183 & 694 & 1,960 & 31 & 76 & 130 & 2.99 & 5.3 & 6.80 & 8.1 \\
\hline 27 & 380 & 1,450 & 4,180 & 57 & 88 & 110 & 5.48 & 11.1 & 14.10 & $(5)$ \\
\hline 29 & 188 & 710 & 2,010 & 25 & 82 & 140 & $\left(^{6}\right)$ & (6) & $\left.{ }^{6}\right)$ & ${ }^{(6)}$ \\
\hline 30 & 464 & 1,770 & 5,090 & 57 & 110 & 150 & $\left({ }^{3}\right)$ & $\left({ }^{3}\right)$ & $\left({ }^{3}\right)$ & $\left({ }^{3}\right)$ \\
\hline 35 & 1,310 & 4,760 & 13,200 & 19 & 50 & 82 & 1.30 & 3.9 & 7.60 & 11.4 \\
\hline 36 & 325 & 1,240 & 3,570 & 25 & 76 & 130 & 1.24 & 2.5 & 3.30 & 4.2 \\
\hline 37 & 282 & 1,080 & 3,080 & 31 & 69 & 110 & .87 & 2.0 & 2.95 & 4.0 \\
\hline 38 & 250 & 955 & 2,730 & 31 & 69 & 120 & 1.72 & 7.3 & $\left({ }^{5}\right)$ & $\left(5^{5}\right)$ \\
\hline 39 & 242 & 922 & 2,630 & 38 & 69 & 130 & 1.84 & 4.0 & 5.40 & 7.1 \\
\hline
\end{tabular}

\footnotetext{
${ }^{1}$ From Hjalmarson and Kemna (1991).

${ }^{2}$ Representative grain size determined at each site from a relation between the grain size and the cumulative percentage of grains smaller than the particular sieve size.

${ }^{3}$ Sample not taken.

${ }^{4}$ Estimated from visual comparison with sites 1 and 2 .

${ }^{5}$ Sample amount not sufficient to compute.

${ }^{6}$ Sample not taken because channel bed is well-cemented rocks that are resistant to erosion. Deposits of mostly sand and gravel were sparsely scattered along the channel bed.
} 
may be controlled more by the rate of weathering of the mountain rock than by the rate of fluvial transport. The weathered rock is easily moved by small floods; however, because of the short duration of typical floods, there may not be sufficient energy to transport all the sandand-gravel material past the PD's during a single runoff event. Small, local deposits of sand and gravel are present in the channels of the upper drainage basin; however, the bed material typically is boulders and cobbles in the stage-confined channels upstream from the PD's. Drainage basins above sites 1-3 are exceptions where large amounts of sand and small gravel are in the beds of the many channels incised into the pediment. Also, according to Hereford (1987, p. 956), the bare-rock mountain slopes suggest that the weathering is less rapid than the fluvial transport. Weathering of the mountain slopes probably controls the amount of sediment available for transport, and because there is little runoff, the typical annual amount of sediment passing the PD's appears to be limited.

At some of the sites, at least one of the channel banks at the PD is erosion-resistant bedrock (fig. 20B). At other sites, the banks and channel bed are erosion-resistant, cemented conglomerate (fig. 12D). The channels at most of these sites are not fully free to self-form, and the channel geometry is influenced to a large degree by older erosion-resistant rock and (or) cohesive material. Most of the channels may be incised because the rate of mountain-channel downcutting is greater than or equal to both the rate of mountain uplift, if any, and the erosion of the alluvial-fan deposits adjacent to the mountains as previously described.

The occurrence of incised channels with stable banks in Maricopa County is related to the age of alluvial fans. As fans become old, they become less active or more stable as erosion tends to offset deposition. Sediment from the drainage basin was deposited throughout the fan surface during the early stages of fan development. As the fans grow, the periodic deposition of sediment proportionately becomes less over a unit area of the fan surface. Parts of the fan become less active in terms of deposition of sediment delivered from the drainage basin past the PD (Harvey, 1989, p. 142-143). Inactive areas become subject to erosion from local rainfall and runoff, and the erosional areas progressively increase in size and number. In areas like Maricopa County where the mountainous areas are small relative to the alluvial-plain areas, the relief age of the mountains is old (Lustig, 1969, p. 62). Sediment transport past the PD's is limited, the channels of many fans are entrenched, and the banks of the channels are stable.

\section{HYDRAULIC GEOMETRY}

Hydraulic-geometry relations have been used as a basis for defining potential flood hazards on alluvial fans (Dawdy, 1979). Hydraulic-geometry relations are power functions that relate channel width, mean channel depth, and velocity to discharge at a channel cross section. Dawdy assumed that a rectangular channel was formed by floodflow at critical-flow velocity. This section of this report provides an examination of this assumption using surveyed cross sections and estimated Manning's roughness coefficients at sites 2 and 23 that have flood-hazard degrees of 6 and 10 , respectively. The relations for the cross sections also are compared to theoretical relations for sections with cohesive and noncohesive bank material. Field evidence presented here shows that the channels are not shaped as described by Dawdy and the channels are formed in cohesive bank material.

The cross section of the channels of DFA's depends on many factors, such as the channel slope, sediment load, underlying material, vegetation along the banks, and the magnitude, frequency, and duration of floodflow. The change of cross-section shape along a channel depends on whether the cross section is on a bend or a straight reach of the channel. For example, the shape of cross sections in straight, uniform reaches of cohesive material exhibit certain preferred characteristics. These characteristics can be described by hydraulic geometry (geometry-discharge relations). The continuity equation for the instantaneous discharge $(Q)$ is:

$$
Q=W D V
$$

where

$$
W=\text { width of the channel, in feet, }
$$




$$
\begin{aligned}
D= & \text { mean depth of the channel, and } \\
V= & \text { mean velocity of the discharge that } \\
& \text { formed the channel. }
\end{aligned}
$$

To represent the geometry of the uniform channel section:

$$
Q=k Q^{b} Q^{f} Q^{m}
$$

where

$k=$ product of the coefficients $C w, C b$, and $C v$ defined below, and is equal to one, and the sum of the exponents $b, f$, and $m$ is equal to one.

The hydraulic-geometry relations at a given cross section or at various cross sections along a stream for channel width, depth, and velocity can be expressed by the equations:

$$
W=C w Q^{b},
$$

where

$$
\begin{aligned}
W= & \text { width of the channel, in feet; } \\
C w= & \text { constant related to the size of the } \\
& \text { channel; } \\
Q= & \text { peak discharge, in cubic feet per second, } \\
& \text { that formed the channel; and } \\
b= & \text { constant exponent; }
\end{aligned}
$$

$$
D=C b Q^{f}
$$

where

$$
\begin{aligned}
D= & \text { mean depth of the channel, } \\
C b= & \text { constant related to the size of the } \\
& \text { channel, and } \\
f= & \text { constant exponent; }
\end{aligned}
$$

and

$$
V=C v Q^{m},
$$

where

$$
\begin{aligned}
V= & \text { mean velocity of the discharge that } \\
& \text { formed the channel, } \\
C v= & \text { constant, and } \\
m= & \text { constant exponent. }
\end{aligned}
$$

The exponents- $b=0.4, f=0.4$, and $m=0.2$ given by Dawdy (1979, table 1)-are difficult to evaluate for the sample of sites used for this study because discharge of the floodflow that formed the channels is unknown. The exponents at a particular location, however, can be computed and compared with the theoretical and average values of exponents for at-a-station relation (table 4) defined by channel cross sections.

The approach used for this study to test if the above hydraulic-geometry equations apply was to survey cross sections of the stream channel at the primary diffluence for sites where the floodflow is in a single channel. The stage-discharge relation for the reach at the PD's was controlled by the channel conveyance and slope, and the cross sections commonly were in fairly uniform reaches. Using conveyance-slope methods, the exponents for the cross sections at each site were computed for the values of peak discharge of the 2-, 10-, and 100-year floods (tables 3 and 5). The average values for the exponents of the sites were then computed for the 2-, 10-, and 100-year floods (tables 4 and 5).

This method is limited because the channel geometry for the 2-, 10-, and 100-year floods is estimated by the surveyed cross sections when there was no flow. The differences between the geometry of the channels at the peak discharge of interest and at the time that the cross sections were surveyed is unknown, although small differences because of scour and fill during subsequent flow are considered likely. For example, scour of the channel bed by a subsequent flow would tend to increase the computed exponent for channel width (b) and decrease the exponent for mean depth $(f)$.

The average of the exponents of the thirteen sites for the 10-year flood $(b=0.27, f=0.44$, $m=0.29$; table 4 ) are similar to the theoretical exponents for streams with cohesive bank material ( $b=0.25, f=0.43, m=0.32$; table 4 ). The average exponents for the 10-year flood also are similar to the average exponents for ephemeral streams in the southwestern United States $(b=0.29, f=0.36$, $m=0.34$; table 4 ) and for streams in the midwestern United States $(b=0.26, f=0.40, \quad m=0.34$; table 4$)$. The computed average exponents for the 2-year flood ( $b=0.32, f=0.41, m=0.27$; table 4) also are similar to the theoretical exponents for cohesive bank material (table 4). 
The level of the 2-year flood at the PD for the sites was below the banks of the active channel as defined by several authors including Hedman and Osterkamp (1982). According to Hedman and Osterkamp (1982, p. 3), the active channel level is

\begin{abstract}
"...a short-term geomorphic feature subject to change by prevailing discharges. The upper limit is defined by a break in the relatively steep bank slope of the active channel to a more gently sloping surface beyond the channel edge. The break in slope normally coincides with the lower limit of permanent vegetation so that the two features, individually or in combination, define the active channel reference level. The section beneath the reference level is that portion of the stream entrenchment in which the channel is actively, if not totally, sculptured by the normal process of water and sediment discharge."
\end{abstract}

Because the active channel was difficult to define on the basis of the break in bank slope at the PD for several sites, it is uncertain if the level of the 10 -year flood was below the top of the banks of the active channel. At most of the sites, however, much of the flow of the 10-year flood is within the active channel.

The average exponents for the channel width, depth, and velocity for the 100-year flood are different from the exponents for the smaller floods (table 4). At all sites, the level of the 100-year flood was above what appeared to be the active channel but was below the top of the confining banks. At several of the sites, the level of the 100 -year flood was above the small flood plains adjacent to the active channel.

No apparent basis exists for an assumption that hydraulic-geometry relations with average exponents can be applied over a wide range of discharge as in Dawdy (1979). At many channels, the floodflow of the 100-year flood spreads over low terraces and other gently sloping land. For these channels, the width increases rapidly, and as reported by Leopold and Maddock (1953), the hydraulic relations are expected to be different.

Hydraulic-geometry relations at cross sections of sites used for this study are based on surveyed measurements of channel width. Relations for mean depth and velocity of flow, however, are based on conveyance-slope computations using estimated Manning's roughness coefficients. The hydraulic-geometry equation for channel width developed by Dawdy (1979, p. 1409) was applied to the cross sections of the north channel of site 2 (table 2). Dawdy's coefficient and exponent are 9.5 and 0.4 , respectively. The computed channel widths average 34 percent more than the measured channel widths for the 100 -year discharge at the 17 cross sections. The coefficient of variation was 67 percent. The coefficient and exponent for the poorly defined relation between width and 100-year discharge (same form as equation 5) are 1.8 and 0.60 , respectively. This poor agreement between the Dawdy equation $\left(C_{w}=9.5\right.$ and $\left.b=0.4\right)$ and the computed relation $\left(C_{w}=1.8\right.$ and $\left.b=0.60\right)$ for the discharge and channel widths at the 17 cross

Table 4. Theoretical and average hydraulic-geometry exponents for channel cross sections

\begin{tabular}{|c|c|c|c|c|c|c|c|c|}
\hline \multirow{3}{*}{$\begin{array}{l}\text { Com- } \\
\text { ponent }\end{array}$} & \multirow{2}{*}{\multicolumn{2}{|c|}{ Theoretlcal values ${ }^{1}$}} & \multirow{2}{*}{\multicolumn{2}{|c|}{ Average values ${ }^{2}$}} & \multirow{3}{*}{$\begin{array}{c}\begin{array}{c}\text { Assumed } \\
\text { values }\end{array} \\
\begin{array}{c}\text { FEMA } \\
\text { method }\end{array}\end{array}$} & \multicolumn{3}{|c|}{ Computed values $^{4}$} \\
\hline & & & & & & \multicolumn{3}{|c|}{$\begin{array}{l}\text { Average value for peak dlscharge } \\
\text { at Indicated recurrence Interval }\end{array}$} \\
\hline & $\begin{array}{c}\text { Cohesive } \\
\text { bank } \\
\text { materlal }\end{array}$ & $\begin{array}{l}\text { Non- } \\
\text { cohesive } \\
\text { bank } \\
\text { materlal }\end{array}$ & $\begin{array}{l}\text { Ephemeral } \\
\text { streams in } \\
\text { southwestern } \\
\text { United States }\end{array}$ & $\begin{array}{l}\text { MId- } \\
\text { western } \\
\text { United } \\
\text { States }\end{array}$ & & 2 year & 10 year & 100 year \\
\hline Width & 0.25 & 0.50 & 0.29 & 0.26 & 0.40 & 0.32 & 0.27 & 0.11 \\
\hline Depth & .43 & .27 & .36 & .40 & .40 & .41 & .44 & .53 \\
\hline Velocity & .32 & .23 & .34 & .34 & .20 & .27 & .29 & .36 \\
\hline
\end{tabular}


Tabie 5. Coefficients and exponents for width, depth, and velocity for the 2-, 10-, and 100-year floods at the primary diffluence of sites in Maricopa County, Arizona

\begin{tabular}{|c|c|c|c|c|c|c|}
\hline \multirow{2}{*}{ Slie } & \multicolumn{2}{|c|}{ WIdth } & \multicolumn{2}{|c|}{ Depth } & \multicolumn{2}{|c|}{ Velocity } \\
\hline & Coefflclent & Exponent & Coefficient & Exponent & Coefficlent & Exponent \\
\hline \multicolumn{7}{|c|}{ A. 2-year flood } \\
\hline 6 & 15 & 0.38 & 0.07 & 0.38 & 0.97 & 0.24 \\
\hline 22 & 3.4 & .80 & .21 & .12 & 1.4 & .08 \\
\hline 23 & 2.8 & .58 & .21 & .25 & 1.7 & .17 \\
\hline 25 & .21 & .20 & .05 & .50 & .88 & .30 \\
\hline 26 & 23 & .25 & .06 & .45 & .71 & .30 \\
\hline 27 & 15 & .23 & .08 & .46 & .82 & .31 \\
\hline 29 & 27 & .09 & .05 & .55 & .75 & .36 \\
\hline 30 & 35 & .20 & .04 & .48 & .63 & .32 \\
\hline 35 & 13 & .37 & .11 & .38 & .67 & .25 \\
\hline 36 & 3.4 & .58 & .14 & .25 & 2.2 & .17 \\
\hline 37 & 55 & .12 & .04 & .53 & .49 & .35 \\
\hline 38 & 32 & .13 & .05 & .52 & .63 & .35 \\
\hline 39 & 31 & .19 & .05 & .48 & .62 & .33 \\
\hline Mean & & .32 & & .41 & & .27 \\
\hline Stand & leviation & .22 & & .13 & & .09 \\
\hline \multicolumn{7}{|c|}{ B. 10-year flood } \\
\hline 6 & 41 & .23 & .04 & .45 & .61 & .32 \\
\hline 22 & 320 & .01 & .02 & .59 & .21 & .40 \\
\hline 23 & 3.4 & .41 & .18 & .36 & 1.6 & .23 \\
\hline 25 & 7.2 & .38 & .09 & .40 & 1.6 & .22 \\
\hline 26 & 27 & .21 & .05 & .47 & .67 & .32 \\
\hline 27 & .12 & .94 & 1.5 & .04 & 5.6 & .02 \\
\hline 29 & 18 & .16 & .06 & .50 & .90 & .34 \\
\hline 30 & 23 & .27 & .06 & .44 & .75 & .29 \\
\hline 35 & 42 & .23 & .06 & .46 & .42 & .31 \\
\hline 36 & 120 & .03 & .01 & .59 & .50 & .38 \\
\hline 37 & 34 & .19 & .05 & .49 & .60 & .32 \\
\hline 38 & 9.3 & .33 & .11 & .40 & 1.0 & .27 \\
\hline 39 & 83 & .04 & .03 & .58 & .42 & .38 \\
\hline Mean & & .27 & & .44 & & .29 \\
\hline Stand & leviation & .24 & & .14 & & .10 \\
\hline \multicolumn{7}{|c|}{ C. 100-year flood } \\
\hline 6 & 107 & .09 & .03 & .51 & .35 & .40 \\
\hline 22 & 300 & .02 & .02 & .55 & .17 & .43 \\
\hline 23 & 30.2 & .14 & .05 & .52 & .67 & .34 \\
\hline 25 & 170 & .002 & .01 & .66 & .52 & .338 \\
\hline 26 & 83.2 & .04 & .03 & .58 & .43 & .38 \\
\hline 27 & 74.1 & .12 & .03 & .53 & .43 & .35 \\
\hline 29 & 15.5 & .19 & .07 & .49 & .96 & .32 \\
\hline 30 & 36.3 & .20 & .04 & .48 & .63 & .32 \\
\hline 35 & 33.9 & .25 & .06 & .45 & .46 & .30 \\
\hline 36 & 98.0 & .06 & .02 & .56 & .56 & .38 \\
\hline 37 & 74.1 & .08 & .03 & .55 & .44 & .37 \\
\hline 38 & 22.9 & .19 & .06 & .49 & .73 & .32 \\
\hline 39 & 77.6 & .05 & .03 & .57 & .43 & .38 \\
\hline Mean & & .11 & & .53 & & .36 \\
\hline Stand & leviation & .08 & & .05 & & .04 \\
\hline
\end{tabular}


sections may be because of the small range of discharge and the grouping of 5 discharges at $3,080 \mathrm{ft}^{3} / \mathrm{s}$ and 6 discharges at $1,020-1,030 \mathrm{ft}^{3} / \mathrm{s}$. No evidence, however, supports the use of Dawdy's equation at site 2 where the flood-hazard degree is a relatively low value of 6 .

Dawdy's equation also provides a poor prediction of channel width for cross sections in the upper DFA of site 23 (fig. 21). A visual examination of the cross sections shown in figure 21 indicates the channel does not have a rectangular shape and that the equation for channel width may not apply. The channel widths computed using Dawdy's equation for the 2-year and 10-year floods (table 4) were 55 and $129 \mathrm{ft}$, respectively, for site 23. All the measured widths (table 6) are less than the computed widths. The computed widths for the 2- and 10-year floods are 62 and 58 percent more, respectively, than the average channel width measured at the cross sections. The geometry of the cross sections probably is affected by scour and deposition from small flows that are unrelated to the channel-forming floodflow (Dawdy, 1979). Again, however, no evidence supports the equation for channel width of a rectangular channel even at this site with a flood-hazard degree of 10 .

Tabie 6. Characteristics of channel cross sections for 2and 10-year floods at site 23

[Discharge for the 2-year and 10-year floods is 79 cubic feet per second and 685 cubic feet per second, respectively]

\begin{tabular}{|c|c|c|c|}
\hline $\begin{array}{l}\text { Cross section } \\
\text { (See figures } \\
19 \text { and 21) }\end{array}$ & $\begin{array}{c}\text { Width, In } \\
\text { feet }\end{array}$ & $\begin{array}{l}\text { Mean } \\
\text { depth, in } \\
\text { foet }\end{array}$ & $\begin{array}{c}\text { Velocity, } \\
\text { in feet } \\
\text { per } \\
\text { second }\end{array}$ \\
\hline \multicolumn{4}{|c|}{ A. 2-year flood } \\
\hline $21 \mathrm{~A}$ & 39 & 0.49 & 4.1 \\
\hline $21 B$ & 35 & .52 & 4.3 \\
\hline $21 \mathrm{C}$ & (1) & & \\
\hline 21D & 28 & .68 & 4.2 \\
\hline \multicolumn{4}{|c|}{ B. 10-year flood } \\
\hline $21 \mathrm{~A}$ & 46 & 1.9 & 7.8 \\
\hline $21 B$ & 83 & 1.4 & 5.9 \\
\hline $21 \mathrm{C}$ & 117 & 1.2 & 4.9 \\
\hline $21 \mathrm{D}$ & 81 & 1.4 & 6.0 \\
\hline
\end{tabular}

${ }^{1}$ Flow in three channels.
The average exponents at the cross sections of site 23 for the 2-year flood resemble exponents for a rectangular channel (table 7). The small standard deviation for the velocity exponent, however, indicates the average value of 0.30 is different from a value of 0.20 for a rectangular channel. The average exponents for the 10-year flood are different from theoretical and other values of exponents (table 4). These differences may be related to the debris-flow processes that are evident on the DFA of site 23. Along many of the channels of the DFA, unstratified deposits of boulders occur with little imbrication. Some horizontal stratification of recent deposits from small flows exists, but there is a general unstratified jumbled appearance of the deposited boulders (figs. 20C and 20D).

The average value of the exponents for channels at the PD's of sites in Maricopa County is similar to the average exponents for ephemeral streams in the southwestern United States and for streams in the midwestern United States (table 4) given by Leopold, Wolman, and Miller (1964). The scatter of the exponents for channel width for the floods of the specified recurrence intervals is large and may be related to undefined amounts of scour and fill that were present during the floodflows that formed the channels. Also, some of the scatter of the exponents may be related to differences in the processes that form the channels. Because of the fairly large scatter of the $b$ exponents, it does not seem reasonable to apply general relations like those defined by Dawdy (1979) to specific DFA's where the channels are confined by stable banks. Likewise, because of the large scatter of the exponents about the relations defined for streams in the Great Plains and the Southwest (Leopold and Maddock, 1953), there is little reason to apply hydraulic-geometry relations with average values of the exponents to specific sites. The exponents represent general positions of mean relations (Leopold and Maddock, 1953, p. 8). Large differences can exist between the hydraulic and geomorphologic conditions of specific sites as indicated by the wide range of values of the exponents (table 5). The use of average exponents may give a misleading impression of regularity (Park, 1976). Thus, until data are available and the cause of the variation is understood, the use of relations based on average values of the exponents 
of hydraulic geometry to define flood hazards for specific DFA's with relatively low degrees of flood hazards in Maricopa County is considered unjustified.

\section{SUMMARY AND CONCLUSIONS}

Distributary-flow areas (DFA's) in Maricopa County have a wide variety of flood hazards distinguishable on topographic maps and photographs. Floodflow in distributary channels can be separated by high, stable ridges or floodflow can coalesce across several channels. Several areas of old-fan remnants in the DFA's of the sample of sites are above the level of the 100-year flood that emanates from the primary diffluences (PD's). These areas can be distinguished by differences in drainage texture between the old-fan remnants and DFA's.

The 2-year flood is capable of moving the noncohesive channel bed material at all the 13 sites where samples of the bed material were collected or where the median grain size of the bed material was estimated. The competence of the 10-year flood, measured by the largest grain size that could be moved, was an order of magnitude greater than the competence needed to move 90 percent of the bed material. Because of the steep and narrow tributary channels in the basins upstream from the PD's, even small floods can move bed material from the drainage basins. The amount of sediment passing the PD's to the DFA's, therefore, may be related to the amount of weathering of rock in the basins. Because of the small amounts of precipitation and

Table 7. Coefficients and exponents for width, depth, and velocity for the 2-, 10-, and 100-year floods at channel cross sections of site 23

\begin{tabular}{|c|c|c|c|c|c|c|c|}
\hline \multirow{2}{*}{$\begin{array}{c}\text { Cross } \\
\text { section } \\
\text { (See figures } \\
19 \text { and 21) }\end{array}$} & \multirow{2}{*}{$\begin{array}{l}\text { Recurrence } \\
\text { Interval, in } \\
\text { years }\end{array}$} & \multicolumn{2}{|c|}{ Width } & \multicolumn{2}{|c|}{ Depth } & \multicolumn{2}{|c|}{ Velocity } \\
\hline & & Coefficient & Exponent & Coefficient & Exponent & Coefficient & Exponent \\
\hline \multirow{3}{*}{$21 \mathrm{~A}$} & 2 & 4.4 & 0.50 & 0.19 & 0.22 & 1.20 & 0.28 \\
\hline & 10 & 27.5 & .08 & .025 & .66 & 1.41 & .26 \\
\hline & 100 & 30.2 & .14 & .050 & .52 & .67 & .34 \\
\hline \multirow{3}{*}{$21 \mathrm{~B}$} & 2 & 12.6 & .24 & .079 & .46 & .96 & .30 \\
\hline & 10 & 15.2 & .26 & .073 & .45 & .90 & .29 \\
\hline & 100 & $\left({ }^{1}\right)$ & $\left({ }^{1}\right)$ & $\left({ }^{1}\right)$ & $\left({ }^{1}\right)$ & $\left({ }^{1}\right)$ & $\left({ }^{1}\right)$ \\
\hline \multirow{3}{*}{$21 \mathrm{C}$} & 2 & $\left({ }^{2}\right)$ & $\left({ }^{2}\right)$ & $\left({ }^{2}\right)$ & $\left({ }^{2}\right)$ & $\left({ }^{2}\right)$ & $\left({ }^{2}\right)$ \\
\hline & 10 & 41.7 & .16 & .044 & .51 & .54 & .33 \\
\hline & 100 & $\left({ }^{3}\right)$ & $\left({ }^{3}\right)$ & $\left({ }^{3}\right)$ & $\left({ }^{3}\right)$ & (3) & $\left({ }^{3}\right)$ \\
\hline \multirow{3}{*}{$21 \mathrm{D}$} & 2 & 11.0 & .23 & .085 & .47 & 1.07 & .30 \\
\hline & 10 & 14.8 & .26 & .074 & .45 & .91 & .29 \\
\hline & 100 & $\left({ }^{3}\right)$ & $\left({ }^{3}\right)$ & $\left(3^{3}\right)$ & $\left({ }^{3}\right)$ & $\left({ }^{3}\right)$ & $\left({ }^{3}\right)$ \\
\hline \multicolumn{8}{|c|}{ 2-year flood } \\
\hline Mean & & & .32 & & .38 & & .30 \\
\hline $\begin{array}{l}\text { Standard } \\
\text { deviation }\end{array}$ & & & .15 & & .14 & & .01 \\
\hline \multicolumn{8}{|c|}{ 10-year flood } \\
\hline Mean & & & .19 & & .52 & & .29 \\
\hline $\begin{array}{l}\text { Standard } \\
\text { deviation }\end{array}$ & & & .09 & & .10 & & .03 \\
\hline
\end{tabular}

${ }^{1}$ Flow over right bank to distributary channel.

${ }^{2}$ Flow in three channels.

${ }^{3}$ Flow over both banks to distributary channels. 
runoff for basins in Maricopa County, the amount of sediment entering most DFA's probably is small.

The width, depth, and velocity exponents of the hydraulic-geometry relations at the PD's of the sites are similar to the average exponents of stream channels in other areas in the United States. Because of the wide scatter of the exponent values of channel width, however, the use of stochastic method based on average hydraulic-geometry relations to define flood hazards is considered inappropriate for characterizing flood hazards for specific distributary-flow areas in Maricopa County. The exponents for the channels in Maricopa County were determined using conveyance-slope methods, and the discharges for specified recurrence intervals were estimated using a regional flood-frequency relation.

Except for actively aggrading alluvial fans, there is no evidence to support the use of stochastic modeling of flows and flood hazards on distributary-flow areas. Dawdy's method appears warranted only for active alluvial fans where the flood-hazard degree is high. The degree of flood hazard of DFA's in southwestern Arizona probably is related to the amount of weathering of the drainage basins and the associated decrease in sediment supplied to the DFA environment. The distributary channels on many DFA's appear to be eroded in the calcreted surfaces of the DFA's. The channel banks are composed of cohesive material that resists lateral movement of the flow paths. Because the flow paths on these DFA's in southwestern Arizona are stable and floodflow generally is restricted to defined distributary channels that are within the landforms, potential flood hazards of DFA's can be defined using traditional channel conveyance-slope methods.

Unstable DFA's commonly are characterized by channels that are perched above the adjacent land surface. Floodwater can overtop or breach the perched banks and spread over the adjacent low-lying land. The trees tend to be scattered over the DFA instead of along the channels. A change in type, size, and density of vegetation commonly occurs at the fan boundaries, and there are few saguaro on the DFA. The perched channels, and associated potentially changing flow paths, the low ridges separating the channels, the undeveloped soils near the land surface, the absence of varnished stones, and the scattered appearance of the unsorted boulder deposits point to the alluvial-fan processes at work with associated debris flows or high sediment loads emanating from the drainage basin.

The abundance of large palo verde trees and other vegetation along incised distributary channels, the absence of evidence of flow-path movement based on the comparison of sequential aerial photographs, the degrading and stable appearance of the distributary channels observed during field reconnaissance, and the developed and stable soils depicted in soil surveys along the ridges separating the distributary channels of the DFA's with low degrees of flood hazard are considerable evidence for stability of the flow paths. Little, if any, evidence exists of flow-path movement in such areas. The unchanging paths of flow in DFA's is considered a much more significant indication of the degree of flood-hazard than the precise definition of the amount of flow in each of the distributary channels. The stable paths of flow indicate that streamflow processes are at work and not alluvial-fan processes and associated debris flows.

\section{SELECTED REFERENCES}

Bull, W.B., 1977, The alluvial-fan environment, in Progress in Physical Geography: London, Edvard Amold, Ltd., v. 1, p. 222-270.

Burkham, D.E., 1988, Methods for delineating floodprone areas in the Great Basin of Nevada and adjacent States: U.S. Geological Survey WaterSupply Paper 2316, 20 p.

Camp, P.D., 1986, Soil survey of Aguila-Carefree area, parts of Maricopa and Pinal Counties, Arizona: U.S. Soil Conservation Service report, $306 \mathrm{p}$.

Cooley, M.E., 1977, Map of Arizona showing selected alluvial, structural, and geomorphic features: U.S. Geological Survey Open-File Report 77-343, 29 p.

Dawdy, D.R., 1979, Flood-frequency estimates on alluvial fans: American Society of Civil Engineers, Journal of the Hydraulics Division, v. 105 , no. HY-11, p. 1407-1413.

1981, Flood-frequency estimates on alluvial fans-Closure: American Society of Civil Engineers, Journal of the Hydraulics Division, v. 107 , no. HY-13, p. 379-380.

DMA Consulting Engineers, 1985, Alluvial fan flooding methodology-An analysis: Federal Emergency Management Agency Contract EMW-84-C-1488, $79 \mathrm{p}$. 
French, R.H., 1987, Hydraulic processes on alluvial fans: Amsterdam, Elsevier Scientific Publishing Company, 244 p.

1992, Preferred directions of flow on alluvial fans: American Society of Civil Engineers, Journal of the Hydraulics Division, v. 118, no. 7, p. 1002-1013.

Harvey, A.M., 1989, The occurrence and role of arid-zone alluvial fans, in Thomas, D.S.G., ed., Arid Zone Geomorphology: New York, Halsted Press, p. 136-158.

Hedman, E.R., and Osterkamp, W.R., 1982, Streamflow characteristics related to channel geometry of streams in the western United States: U.S. Geological Survey Water-Supply Paper 2193, 17 p.

Hereford, Richard, 1987, Sediment-yield history of a small basin in southern Utah, 1937-1976, Implications for land management and geomorphology: Geology, v. 15, p. 954-957.

Hjalmarson, H.W., 1978, Delineation of flood hazards in the Cave Creek quadrangle, Maricopa County, Arizona: U.S. Geological Survey Miscellaneous Investigations Series Map I-843-B, 2 sheets.

1984. Flash flood in Tanque Verde Creek, Tucson, Arizona: American Society of Civil Engineers, Journal of Hydraulic Engineering, v. 110 , no. 12, p. 1841-1852.

1991, Flood hydrology of arid basins in southwestern United States, in Kirby, W.H., and Tan, W.Y., eds., Proceedings of the United States-People's Republic of China Bilateral Symposium on Droughts and Arid-Region Hydrology, September 16-20, 1991, Tucson, Arizona: U.S. Geological Survey Open-File Report 91-244, p. 59-64.

Hjalmarson, H.W., and Kemna, S.P., 1992, Flood hazards of distributary-flow areas in southwestern Arizona: U.S. Geological Survey WaterResources Investigations Report 91-4171, 58 p.
Leopold, L.B., and Langbein, W.B., 1962, The concept of entropy in landscape evolution: U.S. Geological Survey Professional Paper 500-A, 20 p.

Leopold, L.B., and Maddock, Thomas, Jr., 1953, The hydraulic geometry of stream channels and some physiographic implications: U.S. Geological Survey Professional Paper 252, $57 \mathrm{p}$.

Leopold, L.B., Wolman, M.G., and Miller, J.P., 1964, Fluvial processes in geomorphology: W.H. Freeman and Company, $522 \mathrm{p}$.

Lustig, L.K., 1969, Trend-surface analysis of the Basin and Range Province, and some geomorphic implications: U.S. Geological Survey Professional Paper 500-D, 70 p.

Park, C.C., 1977, World-wide variations in hydraulic geometry exponents of stream channels-An analysis and some observations: Amsterdam, Elsevier Scientific Publishing Company, Journal of Hydrology, v. 33, p. 133-146.

Schaffranek, R.W., Baltzer, R.A., and Goldberg, D.E., 1981, A model for simulation of flow in singular and interconnected channels: U.S. Geological Survey Techniques of Water-Resources Investigations, book 7, chap. C3, $110 \mathrm{p}$.

Thomsen, B.W., and Hjalmarson, H.W., 1991, Estimated Manning's roughness coefficients for stream channels and flood plains in Maricopa County, Arizona: Phoenix, Arizona, Flood Control District of Maricopa County report, $126 \mathrm{p}$.

Vanoni, V.A., ed., 1975, Sedimentation engineering: New York, American Society of Civil Engineers, Manuals and Reports on Engineering Practice No. 54,745 p.

Wang, Sany-yi, and Wen Shen, Hsieh, 1985, Incipient sediment motion and riprap design: American Society of Civil Engineers, Journal of the Hydraulics Division, v. 111, no. 3, p. 520-538. 